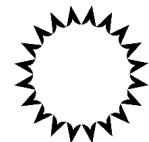

UNIVERSIDADE DE SÃO PAULO

FACULDADE DE ARQUITETURA E URBANISMO

\section{ESPAÇOS CÍBRIDOS:}

MOBILIDADE E LOCATIVIDADE NA ARTE E NA ARQUITETURA PÓS-VIRTUAIS

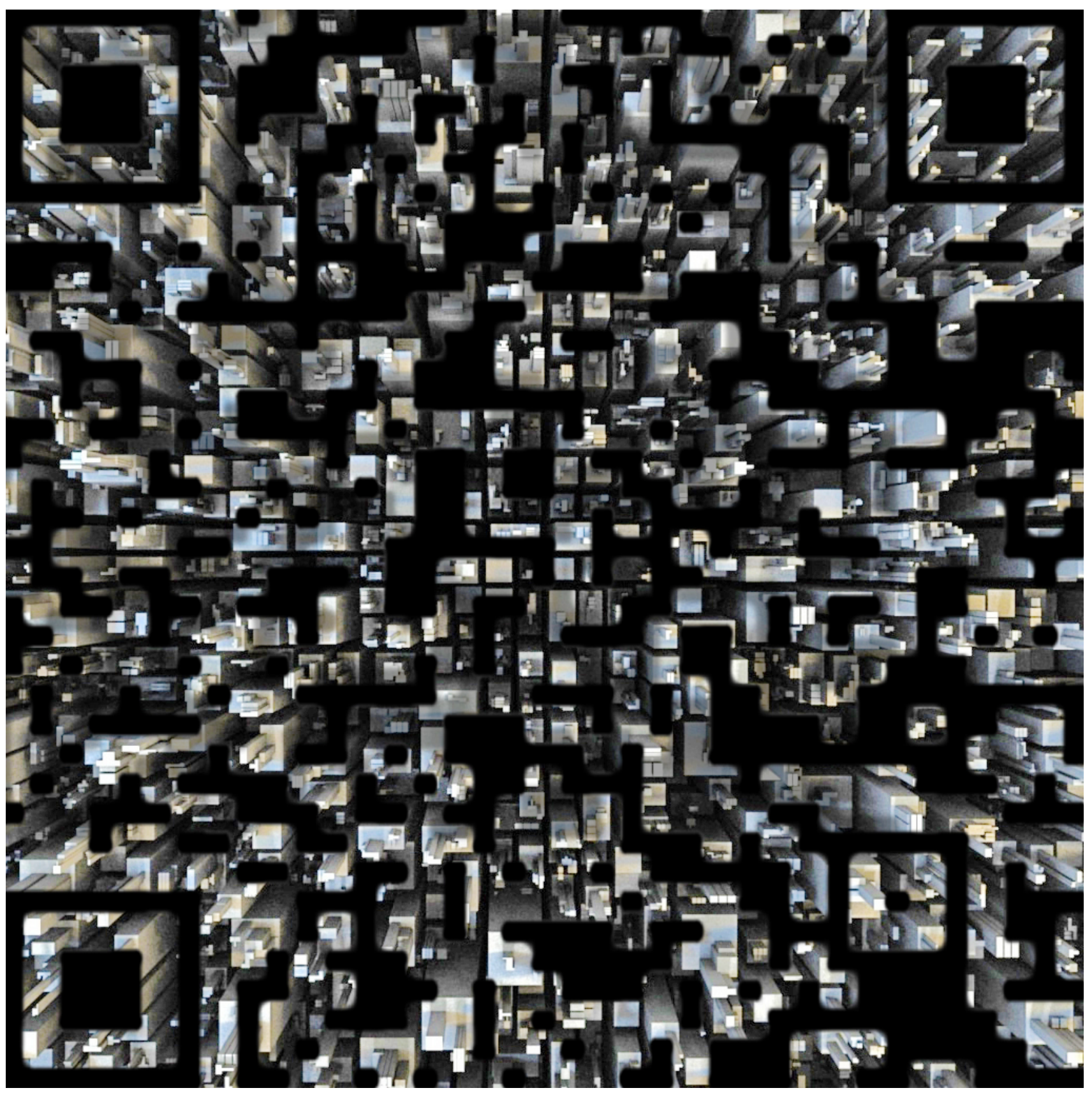


UNIVERSIDADE DE SÃO PAULO

FACULDADE DE ARQUITETURA E URBANISMO

LUCIANA DE PAULA SANTOS

Espaços cíbridos:

Mobilidade e locatividade na arte e na arquitetura pós-virtuais. 


\title{
Espaços Cíbridos:
}

Mobilidade e locatividade na arte e na arquitetura pós-virtuais.

\author{
Dissertação de mestrado apresentada à \\ Faculdade de Arquitetura e Urbanismo da \\ Universidade de São Paulo para a obtenção \\ do título de mestre em arquitetura e \\ urbanismo.
}

Área de Concentração: Projeto, espaço e cultura;

Orientadora: Prof $^{\mathrm{a}} \mathrm{Dr}^{\mathrm{a}}$ Giselle Beiguelman 
Autorizo a reprodução e divulgação total ou parcial deste trabalho, por qualquer meio convencional ou eletrônico, para fins de estudo e pesquisa, desde que citada a fonte.

E-mail da autora: kaleidoeyes@gmail.com

Santos, Luciana de Paula

S237m Espaços Cíbridos: Mobilidade e locatividade na arte e na arquitetura pós-virtuais /

Luciana de Paula Santos. -- São Paulo, 2016.

p. : 125.

Dissertação (Mestrado - Área de Concentração: Projeto, Espaço e Cultura) - FAUUSP.

Orientadora: Giselle Beiguelman

1.Arquitetura 2.Arquitetura móvel 3.Arquitetura experimental 4.Redes urbanas 5.Tecnologia da arquitetura 6.Mídias locativas 7.Mídias táticas 8.Espaços híbridos 9.Espaços cíbridos; pós-virtuais

I.Espaços cíbridos: mobilidade e locatividade na arte e na arquitetura

CDU 72.025.8 
Nome: Luciana de Paula Santos

Título: Espaços Cíbridos: mobilidade e locatividade na arte e na arquitetura pósvirtuais

Dissertação de mestrado apresentada à Faculdade de Arquitetura e Urbanismo da Universidade de São Paulo para a obtenção do título de mestre em arquitetura e urbanismo

Aprovado em: 24/05/2016.

\section{Banca Examinadora}

Prof ${ }^{a}$. Dr ${ }^{a}$. Giselle Beiguelman Instituição: Fau-Usp

Julgamento: Assinatura:

Prof. Dr. Gilbetto Prado

Instituição: Eca-Usp

Julgamento: Assinatura:

Profa ${ }^{a}$ Dr ${ }^{a}$ Daniela Hans Kutschat. Instituição: Fau-Usp Julgamento: Assinatura: 
EXEMPLAR REVISADO E ALTERADO EM RELAÇÃO À VERSÃO ORIGINAL, SOB RESPONSABILIDADE DO AUTOR E ANUÊNCIA DO ORIENTADOR.

O original se encontra disponível na sede do programa.

São Paulo, 23 de julho de 2016. 
Ao Pedro, com amor. 


\section{Agradecimentos}

Agradeço à Giselle Beiguelman pela sensibilidade e pela clareza conceitual com que me orientou e inspirou durante todo o processo desta pesquisa.

Ao professor Paulo César Xavier Pereira, que contribuiu para a desconstrução crítica do projeto inicial de dissertação, em relação às formas de apropriação do espaço urbano.

Aos professores Gilbertto Prado, Daniella Hans Kutschat e Vera Pallamin, que deram contribuições valiosas para a o desenvolvimento desta dissertação.

Ao Dário Vargas, Paloma de Oliveira, Célio Ishkawa, Pedro Pessoa e a toda equipe do projeto Híbrida, pelo compartilhamento de ideias, experiências e insights valiosos em prototipagem experimental.

Aos brilhantes colegas que encontrei nesse percurso: Tânia Soares, Diego Normandi, Marcelo Ferreira, Paula Torres, Renato Boleli Rebouças, Evandro Nicolau, Didiana Prata, Lucas Bambozzi, Acácio Netto e Luiz Antonioli.

Agradeço também aos professores de outras faculdades, que me deram os alicerces para seguir nessa caminhada: Dorival Rossi, Claudio Amaral, Verinha Vilella, Lucia Santaella e Marcelo Moreira Santos.

Por fim, todo o meu amor e gratidão: ao Pedro Aion pela sensibilidade com que me mostra cotidianamente a vida. Ao Martin por caminhar lado à lado comigo. À Suely e ao Homero pelo apoio incondicional, mas também pela sabedoria dos 'chacoalhões' nas horas propícias, apontando sempre para perspectivas mais alegres. Ao Gabriel e à Tuanny pela doçura da partilha. Ao Edson, por ser a fortaleza no momento mais difícil dessa trajetória. Ao José Roberto (mais conhecido como Fidel) e às maravilhosas Sônia, Thalita e Tayra, por serem a família que se escolhe ter.

Toda minha gratidão a vocês! 


\section{Resumo}

Esta pesquisa disserta sobre o processo de convergência entre o espaço urbano e as mídias locativas, que forma um terceiro espaço: o espaço cíbrido. O termo cíbrido foi criado pelo arquiteto Peter Anders, para designar um meio híbrido onde se desenvolvem as práticas sociais relacionadas à cibercultura.

Com a difusão da Internet 1.0 na década de 90, que ocorre a partir da venda massiva de computadores pessoais, as mais variadas vertentes do conhecimento se debruçaram sobre as implicações do surgimento de um novo lugar: o espaço virtual. Porém é especialmente entre os 'artistas digitais' da Net.art e arquitetos que se investigou as formas de perceber, produzir e criar esteticamente este novo lugar.

Uma década mais tarde, o meio virtual sofreu uma nova guinada: a difusão dos dispositivos portáteis de telecomunicação: os smartphones, acoplados com dispositivos de rastreamento, demarcação e mapeamento espacial. As práticas resultantes destas novas mídias: as mídias locativas, associam camadas informacionais aos objetos, às pessoas e aos agenciamentos em rede e localizam esta rede espacialmente.

Para investigar o processo de hibridização dos espaços cíbridos, traçou-se um mapeamento de obras de arte e arquitetura que tratam especificamente deste tema. A seleção desses dois campos de conhecimento para a análise, se justifica por serem áreas correlatas que vêm promovendo mudanças paradigmáticas neste campo e trazendo contribuições essenciais para a compreensão das práticas sociais que envolvem os espaços cíbridos.

Cada projeto selecionado oferece em sua especificidade, o suporte teórico, descritivo, sobre as atuais formas de convergência telemática no espaço e tensionam questões específicas desse processo de hibridização, contribuindo para o avanço do conhecimento acerca do processo de produção, apropriação e compartilhamento destas tecnologias com o espaço urbano. 


\section{Abstract}

This research talks about the issues and process of convergence between urban space and locative media, which form a third space: the Cybrid space. The Cybrid is a term coined by the architect Peter Anders, to designate a hybrid environment where to develop social practices related to cyberculture.

With the spread of Internet 1.0 in the 90's, which takes place from the massive sales of personal computers, the aspects of knowledge have addressed the implications of the emergence of a new place: the virtual space. But it is especially among 'digital artists' of Net.art and architects who investigated the ways of perceiving, producing and aesthetically create this new place.

A decade later, the virtual environment has suffered a new twist: the distribution of portable telecommunication devices: smartphones, coupled with tracking devices, demarcation and spatial mapping. The resulting practices of these new media: locative media, associated informational layers to objects, people and assemblages networking and spatially locate this network.

To investigate the process of hybridization between the informational sphere and space, drew up a mapping of art and architecture works that specifically address this issue.

The selection of these two fields of knowledge for the analysis is justified because they are related areas that are promoting paradigmatic changes in this field and bringing essential contributions to the understanding of social practices involving cybrids spaces.

Each project offers, the theoretical, descriptive support, on current forms of telematics convergence in space and tense specific issues that the hybridization process, contributing to the advancement of knowledge about the production process, ownership and sharing of these technologies urban space. 
Resumo | Abstract

Introdução

\section{CAPÍTULO I}

Espaços híbridos em contexto

1.1- Do processo: Por que espaço cíbrido?

1.2- Da metodologia: Cartografias relacionais

1.2.a - Análise das relações internas das obras

1.2.b - Tópico de Análise contextual___ 11

1.3- Das questões: Espaços cíbridos, uma delimitação conceitual____ 12

1.3.a - Infraestrutura: a produção em rede.__ 12

1.3.b - Delimitação conceitual: Virtual e Pós-virtual___ 15

1.4- Mobilidade e locatividade no espaço pós-virtual

\section{CAPÍTULO II}

Ponto de transição entre o espaço virtual e pós-virtual

2.1 ARQUITETURA: Uma arqueologia do espaço virtual

2.1.1 - Relações Internas das Obras 21

2.1.2 - Relações Externas das Obras___ 42

2.2 ARTE: 0 ponto de transição para 0 espaço pós-virtual

2.2.1 - Relações Internas das Obras 50

2.2.2 - Relações Externas das Obras 74

\section{CAPÍTULO III}

Planos de consistência e linhas de força

\section{1- Agenciamentos no espaço pós-virtual: Mobilidade e Locatividade}

3.1.1 - Cultura da mobilidade

3.1.2 - Vigilância e controle

3.2- Percepção, produção e partilha nos espaços híbridos:

3.2.1 - Percepção e produção mediadas

\section{Considerações Finais \\ Bibliografia \\ Referências \\ Glossário}




\section{Introdução}

A transição produtiva, que a atual fase do capitalismo hegemônico vem operando na contemporaneidade, é o resultado da fusão e rearranjo dos processos políticos, sociais, econômicos e culturais que vêm ocorrendo desde a transição para a pósmodernidade. Negri e Hardt (2005) indicam que importantes mudanças ocorrem na economia global, onde a produção não é apenas concebida na esfera econômica e sim, se amplia na escala social, desde a produção de bens materiais e imateriais até a produção de comunicações, relações e formas de vida.

O meio técnico-científico-informacional (SANTOS, 2000), que possibilitou essa transição para novos modos de produção, foi capaz de operar uma revolução sem precedentes nas formas de comunicação e produção: o meio informacional, que vem promovendo profundas mudanças nos modos de perceber, pensar, produzir e compartilhar este espaço. O meio informacional compreende toda a cibercultura que se expande entre o final do século XX e o começo do nosso século.

Durante a difusão da internet 1.0 na última década do séc. $X X$, os teóricos da rede, a Net.Art. e a Arquitetura Virtual abordavam o espaço virtual como um espaço paralelo de potências e possibilidades, desvinculado do espaço físico, o que movimentou a idéia de desmaterialização da cultura. No entanto, na fase da Internet 2.0, que se desenvolve a partir do início deste século, presenciamos a formação de espacialidades vinculadas ao meio informacional, desde o desenvolvimento de objetos conectados, sensíveis e responsivos até a formação de polos regionais, interconectados em rede. 0 desenrolar da cibercultura associado ao desenvolvimento dos satélites de geolocalização, da Internet das coisas e da difusão do uso de dispositivos móveis, indicam que, ao contrário do que se previa inicialmente, não houve a negação da espacialidade física em prol do desenvolvimento das redes de comunicação, tampouco houve a negação da virtualidade, mas a hibridização destas esferas.

Se inicialmente, com a implantação da Internet 1.0, promovia-se o upload de dados para o ciberespaço, no segundo momento, a atual fase da Internet 2.0, observamos o download dessas informações e a interconexão em rede de pessoas, objetos, edifícios, meios urbanos e regiões. Nesta fase, as novas tecnologias telemáticas não suplantam outras formas de produção veiculadas em períodos anteriores, tais como a produção 
analógica, não se trata de uma linha evolutiva em que uma etapa suplanta e destrói a outra, mas ao contrário, verifica-se a prevalência de determinadas estruturas tecnocientíficas, que persistem ou até se intensificam em meio determinadas formas de produção. A tentativa de ver a produção tecnológica como um ponto de ruptura com as formas de produção anteriores, pode tanto se calcar em uma visão neopositivista de um progresso centrado exclusivamente na superação técnica e obsolescência programada.

No entanto as pós-mídias, vêm aderir-se ao espaço e às produções anteriores deslocando constantemente as fronteiras entre perceber, compreender, e produzir estes meios e criando novas camadas informacionais, hibridizadas com meios anteriores de produção. No campo da arte, as mídias locativas, surgem como um tensionamento da idéia de desmaterialização (TUTERS, 2006), abrindo um novo campo de potências para a cibercultura, que ultrapassa a tela do computador e se mescla aos objetos, às pessoas e ao meio urbano, adicionando camadas informacionais e atravessando significantes antes restritos à plataforma representacional da tela. Ainda nesse campo, se ampliam as possibilidades de agenciamentos no espaço público, agora, expandido pela conexão com o ciberespaço.

Tanto o processo de adição de camadas informacionais ao espaço, como a utilização massiva de dispositivos móveis com sistemas de geolocalização, operam a formação de espacialidades dinâmicas, que passam a ser praticadas socialmente e envolvem mobilidade física e informacional promovendo uma série de desterritorializações sobre o conceito de mobilidade e lugar, levantando questões como a pervasividade destes meios, a vigilância e o controle, o deslocamento de fronteiras entre público e privado, mas também, pela via positiva das potências agenciadas, possibilitando os agenciamentos em rede, mapeamentos colaborativos, descentralização de banco de dados, a formação de processos participativos dentro das cidades, a ampliação da mobilidade e o nomadismo, dentre outras questões relevantes para a compreensão das possibilidades deste novo meio, cíbrido.

A mobilidade pode ser entendida como uma rede de agenciamentos, operada por indivíduos conectados, que gera espacialidades, campos comunicacionais de interação que operam o tempo e a dimensão física dos acontecimentos em tempo real. A figura do nômade como agente central deste agenciamento, se diferencia do que compreendemos sobre as comunidades nômades, caracterizadas por linhas de errância e deslocamento em territorialidades específicas. O nomadismo contemporâneo mesmo que exercido 
individualmente é comunitário, intersubjetivo e se reterritorializa constantemente em diferentes territórios informacionais. (PRADO, 2008)

A mobilidade, em interação com os dispositivos móveis realiza a produção informacional do espaço cotidiano das cidades, produzindo uma imensa quantidade de dados geolocalizados e, nesse sentido, a mobilidade é profundamente coletiva e passa por uma serie de disputas por novos territórios, digitais, informacionais, híbridos. Na arte e na arquitetura, tais agenciamentos móveis e locativos, promovem um deslocamento no conceito de espacialidade física, informacional e híbrida (pós-virtual) tensionando estética e politicamente esta transição. Seja através de obras que proponham a adição de camadas informacionais ao espaço urbano, como veremos mais adiante com a criação coletiva de jardins sonoros, seja com a ampliação da voz de pessoas em situação de risco ou invisibilidade social como os motoboys e mesmo com a elaboração de táticas coletivas de cruzar fronteiras políticas.

Para sistematizar e investigar essas questões, propõe-se um mapeamento de obras de arte e arquitetura que incorporaram os territórios informacionais como meio de produção e tensionamento criativo de suas virtualidades e devires, atribuindo novos usos para as mesmas tecnologias.

Os arquitetos escolhidos fazem parte da primeira geração de arquitetos formados com o CAD, ou seja, aqueles que assumiram as possibilidades do espaço virtual como meio para chegar à uma arquitetura híbrida. Trata-se de uma geração de arquitetos experimentais que buscou reformular os conceitos de espacialidade virtual, a partir desse meio. Arquitetos que pensaram os modos possíveis desta hibridização.

Por outro lado, o grupo de artistas selecionados já faz parte da geração posterior à Net.Art. Eles incorporam as mídias locativas e propõe relações diretamente no espaço cíbrido, que já está repleto de camadas informacionais, tais como territórios de transmissão de sinal wi-fi, Qr-codes, R.A.-Realidade Aumentada, tecnologias de rastreamento e localização, como o Rfid.

Portanto, este mapeamento busca delinear alguns aspectos potentes em meio a produção do espaço virtual e pós-virtual, bem como as possibilidade experimentais de se produzir um espaço cíbrido. Não se trata aqui de um mapeamento extensivo, pois não se busca esgotar o campo das obras produzidas no espaço pós-virtual ou cíbrido, mas sim de traçar as linhas de força que atravessam este pequeno mapeamento rumo à 
outras obras e outros devires, que deem conta de enfrentar os desafios e questões desta nova espacialidade informacional. Embora a arte e a arquitetura tratem de processos diferentes de concepção e elaboração dos espaços cíbridos, cada área contribuiu com a revisão do discurso puramente tecnológico desses meios e traz para o campo desta investigação uma multiplicidade de novas questões, que merecem ser estudadas à luz desse fenômeno relativamente recente: o espaço cíbrido.

Dessa forma essa pesquisa pretende contribuir para o avanço do conhecimento em relação à hibridização entre o espaço físico e o espaço informacional, que constitui o espaço cíbrido, buscando conceituar este espaço e diferenciar as práticas politicas e estéticas, que emergem dessa hibridização, mais especificamente na arte e na arquitetura contemporâneas. 


\section{CAPÍTULO I}

\section{Espaços cíbridos em contexto}

\section{1- Do processo: Por que o espaço cíbrido?}

Particularmente, meu interesse pelo espaço pós-virtual começou ainda na graduação em arquitetura e urbanismo, durante o período de transição da internet 1.0 para a internet 2.0. Como faço parte da geração que cresceu nos anos 90, mais especificamente em um grande centro urbano na América Latina e ainda com acesso restrito à Internet, meu contato com os meios de reprodução técnica de imagens e sons e telefonia se deu por meio de 'brincadeiras analógicas' com o rádio, walkman, gravadores de fitas $k 7$, discos, vitrola, vídeo-cassete, câmera fotográfica e filmadoras analógicas. Sou parte portanto da geração que conviveu com o último meio tecnocientífico de técnicas analógicas de produção e difusão massiva de mídias.

Somente durante a graduação em arquitetura e urbanismo e mesmo assim, depois de um ano de desenhos técnicos em pranchetas, entrei em contato com os meios digitais para começar a pensar o espaço a partir da modelagem numérica computacional de imagens (em uma época em que ainda se comprimia e particionava arquivos digitais para caberem em 3 disquetes). Justamente nessa época (2001-2004) começaram a se difundir os estudos e dispositivos de rastreamento e geolocalização, em internet das coisas e mídias locativas. Foi dessa transição e da experimentação de dois modos distintos de ver, apreender, compreender e produzir o espaço analógico e digital, que meu interesse pelo espaço híbrido surgiu, ainda em meio a questões como: desmaterialização da cultura, nomadismo, caos, complexidade, arte digital, arquitetura virtual e inteligência coletiva.

De forma diversa, a dança e o movimento, me colocaram em meio a uma questão muito cara à arquitetura contemporânea: o corpo como ponto central de toda experimentação fenomenológica e matriz do pensamento arquitetônico e urbano. Por entender que o espaço não é um meio objetivo e estável, nem se compõe apenas de forma e função como pretendia a positivismo moderno, considera-se que ele é imersivo, sinestésico, fenomenológico e compõe junto ao corpo a nossa primeira interface, que 
articula a percepção, o pensamento e a produção de linguagem e a noção de 'realidade', verdade ou ficção.

A partir desse momento passei a investigar quais arquitetos que compartilhavam dessa linha de pensamento para desenvolver o trabalho final de graduação: traçar protótipo de uma arquitetura sensível que fosse capaz de dançar, tarefa impossível e megalomaníaca para a época. Atualmente, um espaço feito com materiais sensíveis que incorpore a mobilidade, não é mais uma idéia tão megalomaníaca, e dispomos hoje em dia de meios e linguagens mais propícios para experimentar e criar tais propostas. Esta possibilidade, no entanto faz parte de um esforço coletivo, de todos os campos do conhecimento, que vêm desde o surgimento dos primeiros computadores e dão forma e sentido a este novo meio tecno-científico-informacional (SANTOS, 2000): o espaço pósvirtual ou cíbrido.

Há no entanto uma diferença fundamental entre estes dois termos, que coloca o primeiro em um campo mais aberto de atribuições e que o situa historicamente em relação ao meio anterior, mas ainda sim contíguo a ele: o espaço virtual, demarcando a transição entre dois meios distintos de produção do espaço informacional: o virtual e o pós-virtual. 0 espaço pós-virtual é portanto o meio virtual que se expandiu para a dimensão física dos objetos, dos edifícios, do espaço urbano e até mesmo das pessoas, aumentando-os virtualmente. No entanto, espaço pós-virtual, só foi possível a partir do surgimento de uma série de tecnologias militares de geolocalização, que hoje foram amplamente difundidas pelos dispositivos móveis de comunicação e que assimilaram o espaço virtual, associando-o às coordenadas geográficas, que permitiram a demarcação digital dos espaços físicos, inscrevendo-os junto ao espaço virtual.

O termo hibridização ${ }^{1}$ foi amplamente difundido a partir da década de 90 , antes mesmo da possibilidade técnica de se hibridizar de fato estes dois espaços, o termo se referia a todo processo de incorporar textos, sons, imagens, dentro à linguagem virtual, em um processo de digitalização massiva de meios analógicos, em uma espécie de upload de informações para o espaço digital.

Nesta época começaram a se formar os primeiros arquitetos que incorporaram o meio virtual em suas experimentações, os chamados 'Natural Born CAD Designers' (PONGRATZ e PERBELLINI, 2000). Estes arquitetos começaram a desenvolver

\footnotetext{
${ }^{1}$ Consultar as obras seminais de Pierre Levy, Vilém Flüsser, bem como Manuels Castells e Gilles Deleuze;
} 
metodologias e estratégias para reformular as formas de representação e a objetivação formal do projeto arquitetônico, que têm sido alvo de críticas dos arquitetos contemporâneos, pelo menos desde a Segunda Guerra (NESBIT, 2008). Esta geração, desenvolveu, e ainda desenvolve, inúmeras experimentações em torno da hibridização do espaço físico e do espaço virtual. Dentre os inúmeros processos experimentais, Peter Anders, cunhou o termo Cíbrido, para se referir a ao espaço híbrido da arquitetura que incorpora os meio virtual em seu projeto. 0 termo cíbrido se refere a um continuum entre o espaço virtual e físico, pois para Peter Zelner, esta distinção não existe a priori. Peter Zelner, adota, como Deleuze (1996) e Pierre Lévy (2007), a relação conceitual entre o virtual e o atual, inserindo o campo virtual em uma categoria conceitual e temporal de devires, que se atualizam constantemente (DELEUZE apud. ALLIÉZ, 1996). 0 virtual não se opõe ao real, nem à materialidade física das coisas. Ainda que não esteja fixo em nenhuma coordenada de tempo e espaço, o virtual existe e é real, mas está desterritorializado, pelo menos até a fase da internet 1.0. Para Vilém Flüsser (2010), o virtual é dotado da materialidade dos impulsos magnéticos, que mesmo não sendo visível, e portanto, estando não circunscrita ao olhar como apreensão do real, existem e possibilitam que toda a sociedade tecno-cientifico-informacional estabeleça as práticas de produção informacional.

"A tecnologia digital dilui a distinção entre o sensorial e as medidas no mundo. 0 computador é uma simbiose de hardware e software. Nós podemos tocar o teclado e o mouse, mas não podemos ver o software. O Hardware é palpável, o software não é. Um ainda está inoperante um sem o outro. 0 computador, então é um híbrido de entidades complexas. Cada um tem o seu próprio nível de existência, ontologicamente, no que diz respeito ao usuário, apesar de que eles são mutuamente dependentes umas das outras. Essas dependências entre material eletrônico e de entidades têm grandes implicações para as artes de desenho industrial e da arquitetura. Um relacionamento particular entre as concepções físicas e o ciberespaço assim, usa-se o termo para designar como Cíbrido" (ANDERS, P. apud. KINSLEY, 2003, s/i , tradução nossa).

Assim, adotamos o termo cíbrido como forma de referenciar a hibridização que ocorre entre esses dois campos contínuos e diferenciados: o meio virtual e o meio físico, o que possibilita entender o espaço virtual em continuidade com a espacialidade e a atualização da arquitetura e da arte. 


\section{2- Da metodologia: Cartografias relacionais.}

Para compreender o impacto da convergência dos espaços informacional e físico, e seu desdobramento sobre a produção, apropriação, apreensão e conceituação desse espaço, adotamos como metodologia, a leitura de projetos selecionados nos campos da arte e da arquitetura contemporâneas, que tensionam especificamente essas questões. O mapeamento não visa esgotar o tema, mas apontar virtualidades e potências possíveis operadas política e esteticamente pela arte e pela arquitetura em torno do espaço cíbrido.

A seleção desses dois campos de conhecimento para a análise, se justifica por tratarem de áreas correlatas, que vêm sofrendo mudanças paradigmáticas e trazendo contribuições essenciais para a concepção estética desse novo meio.

Rob Von Kranemburg (2008), em Internet of Things, constata que o ponto de mutação da Net Art e da arquitetura virtual para o espaço cíbrido é a Internet das Coisas, pois esta transita da tela, como interface informacional significante, para o espaço dos objetos cotidianos que passam a incorporar a máquina computacional e tornam-se conectados em rede, captando, armazenando e transmitindo dados informacionais entre si, sobre a interação com seus usuários. Incorporando um nível de pervasvidade sem precedentes, que marca a transição das sociedades industriais para as pós-industriais, ou como definiu Deleuze (1990), para as sociedades de controle.

Nesse sentido, adotamos como ponto de partida o mapeamento dos projetos de arquitetura, pois se trata de um mapeamento que estuda a primeira geração de arquitetos experimentais que incorporaram o meio virtual ao espaço urbano e arquitetônico, questionando alguns dos mais fundamentais pressupostos metodológicos e epistemológicos da compreensão positivista de espaço, que herdamos da modernidade.

$\mathrm{Na}$ etapa seguinte mapeamos os projetos de arte feita com mídias locativas e móveis, pois estes projetos marcam a transição estética ao incorporar a interação mediada. Pois se, em um período anterior, a Net Art promovia uma percepção descorporalizada através da plataforma da tela, nesse momento, os projetos de mídias 
locativas se apropriam da mobilidade para inserir o corpo e as relações humanas como principal agenciamento dos espaços cíbridos, promovendo a estética relacional e radicante (BORRIAUD, 2009) em meio à localidades específicas.

Como forma de sistematizar este conhecimento dividiu-se essa dissertação em três partes, o primeiro capítulo promove uma visão contextual do processo de convergência dos espaços cíbridos e aponta para sua conceituação.

No capítulo seguinte, com os mapeamentos, cada projeto selecionado em arte e arquitetura, oferece em sua especificidade um suporte teórico, descritivo e referencial de questões que tensionam o processo de cibridização ${ }^{2}$ (ANDERS, 2001) do espaço informacional, contribuindo para o aprofundamento conceitual e crítico do processo de produção, apropriação e impactos destas tecnologias nos campos investigados. Para cada mapeamento, traçamos o estudo pontual de cada obra e o estudo comparativo em contexto, considerando os meios de produção incorporados, tecnologias e conceitos envolvidos. O levantamento imagético, bibliográfico, de fontes de dados e a contextualização com o tema da pesquisa é feito através de leitura instrumental, fichamento e a análise da bibliografia, que dêem suporte conceitual aos paradigmas estéticos lançados pelos projetos escolhidos, a fim de criar um panorama crítico dessas novas vertentes de produção do espaço.

A seguir detalhou-se a metodologia empregada para análise pontual de cada projeto selecionado, bem como para a análise comparativa entre os projetos, realizando, por fim, a análise contextual dentro da temática desta pesquisa, no ultimo capítulo.

\section{2.a - Análise das relações internas das obras:}

Apresenta os fichamentos de análise de como a linguagem e o meio digital específicos de cada projeto, respectivamente agenciam sua linguagem:

- Título, data e autores;

- Palavras-chave;

- descrição;

- objetivos;

- metodologias;

- tecnologias envolvidas;

- reprodutibilidade da obra;

${ }^{2} 0$ termo cibridização é um neologismo, um termo criado inicialmente pelo arquiteto Peter Anders em 2001. 
- modos de extroversão;

- Imagens;

\section{2.b - Tópico de Análise contextual}

Esta etapa da pesquisa realiza a análise das relações externas das obras, a partir da abordagem comparativa das obras selecionadas, levando-se em conta os modos de pensar, representar, produzir e se relacionar no espaço em contexto com seu meio anterior a fim de contribuir para a conceituação e ampliação do conhecimento do espaços cíbridos sob a perspectiva crítica da arte e da arquitetura.

No terceiro capítulo, selecionou-se três aspectos que permeiam toda a produção estudada, visando aprofundar as relações em torno da temática desta pesquisa: a mobilidade e a locatividade na arte e na arquitetura pós-virtuais. Partiu-se então da cultura da mobilidade para se entender como esta se relaciona com a locatividade e a ideia de permanência e durabilidade da arquitetura e como esta última incorpora o paradigma móvel. Em seguida priorizou-se o aspecto da ubiqüidade das redes cíbridas, que ao ampliar o espaço físico, rompem com os pressupostos mais arraigados de propriedade física e também intelectual da arquitetura, da arte e da vida. Por fim, outro aspecto relevante, dessa produção recente, trata de compreender de que formas o espaço cíbrido agencia a percepção, a produção e o compartilhamento mediados. Se inserindo e talvez modificando o cenário das formas de produção destes espaços.

No entanto, como esta é uma tarefa por si só muito árdua e ampla para os objetivos a que esta dissertação de mestrado se propõe, optou-se por não esgotar o tema, mas verificar em que cada uma dessas áreas contribuem para a criação da arte e da arquitetura contemporâneas. 


\section{3- Das questões: Espaços cíbridos, uma delimitação conceitual}

\section{3.a - Infraestrutura: a produção do espaço cíbrido em rede.}

A partir de 1990, o desenvolvimento da indústria eletrônica de computação e telecomunicações, por meio de massivos investimentos na formação de infraestrutura, em contínuo desenvolvimento, englobou desde redes de computadores, servidores, banco de dados, satélites, cabos submarinos, antenas de transmissão de sinais, telefonia e serviços. A maior parte desta infraestrutura teve como ponto de convergência as redes telemáticas, que juntas formam as TIC's (Tecnologias da Informação e Comunicação) (LEMOS, 2004). Lucia Santaella, apresenta da seguinte maneira esse contexto:

"As novas tecnologias da informação e comunicação estão mudando não apenas as formas do entretenimento e do lazer, mas potencialmente todas as esferas da sociedade: o trabalho (robótica e tecnologias para escritórios), gerenciamento político, atividades militares e policiais (a guerra eletrônica), consumo (transferência de fundos eletrônicos), comunicação e educação (aprendizagem a distância), enfim, estão mudando toda a cultura em geral. Para Robins e Webster (2000, p. 111), se as forças do capital corporativista e os interesses políticos forem bem-sucedidos na introdução sistemática dessas novas tecnologias - da robótica aos bancos de dados, da internet aos jogos de realidade virtual, então a vida social será transformada em quase todos os seus aspectos. 0 desenvolvimento estratégico das tecnologias da informática e comunicação terá, então, reverberações por toda a estrutura social das sociedades capitalistas avançadas". (ROBINS e WEBSTER, 2000, p.111 apud SANTAELLA, 2003, p.2).

$\mathrm{Na}$ cidade contemporânea as tecnologias informacionais associam-se às redes de transporte, de energia, saneamento, iluminação, comunicação, às condições gerais das metrópoles, levantando questões como: propriedade intelectual, trabalho à distância ou tele-trabalho, exclusão e inclusão digital, vigilância e controle, pervasividade e ubiqüidade das mídias, dentre outras, que são necessárias para a compreensão da cibercultura do século XXI (LEMOS, 2004).

Atualmente, tornou-se impossível pensar esse processo acelerado de formação de um novo meio técnico-científico-informacional (SANTOS, 2000) sem incorporar a complexidade dos novos modos de produção e espacialização das tecnologias digitais e as redes de telecomunicação em interação com o espaço urbano. Dessa forma as redes 
informacionais são um setor chave para compreender as metrópoles pós-industriais contemporâneas, assim como, as redes urbanas de transporte, eletricidade e telecomunicações, eram para a infraestrutura do sistema econômico e social das metrópoles industriais.

As mudanças econômicas, sociais e geográficas das metrópoles capitalistas nos últimos 20 anos, suas estruturas políticas e dinâmicas socioculturais, aliadas ao capitalismo hegemônico, estão no centro desse processo. Juntos, esses centros operam um conjunto de mercados financeiros globais abertos 24 horas, dominando os fluxos financeiros mundiais. Essa nova revolução na infraestrutura é uma das mais profundas mudanças no desenvolvimento das redes urbanas desde o começo do século passado. 0 resultado é o movimento em direção ao gerenciamento, em tempo real, dessas redes (LEMOS, 2004).

Arthur Kroker, cientista político canadense, desde 1994, alerta para o aprofundamento da fratura social que a formação de uma nova classe dirigente, composta pelos "info-ricos": aqueles que detém os modos de produção das infraestruturas de telecomunicações e tecnologias. Os info-ricos seriam uma nova classe formada por administradores, programadores e executores da telemática, uma classe que formaria a nova elite econômica. Contextualizada em uma sociedade de info-ricos e info-pobres, sua análise consiste em demonstrar que a tecnologia da informação não traria a democratização da sociedade, ao contrário: até o momento, os sinais apontam para o alargamento da fratura social entre incluídos e excluídos da sociedade informacional, levantando questões sobre acessibilidade digital como um direito básico para promover a inclusão nas atuais formas de produção.

Segundo André Lemos (2010), as práticas da cibercultura modificam a paisagem comunicacionais e sociais contemporâneas e estabelecem novas relações entre as tecnologias e a sociabilidade, que configuram a cultura contemporânea (LEMOS, 2010). Essa nova configuração cultural, André Lemos chama de "ciber-cultura-remix", retomando o termo ciberespaço, cibercultura e remix, que seriam as práticas de trocas e apropriações discursivas da cibercultura. 0 ciberespaço não atua da mesma forma que o meio informacional imediatamente anterior a ele: as mídias de massa (TV, rádio, jornais, cinema, etc.) e pode reagir de forma diferenciada, em relação ao espaço público e à opinião pública, formada pela cultura de massas.

Socialmente as tecnologias informacionais não atuam na forma unidirecional "um- 
todos" e rompem com a hegemonia midiática de um único discurso sobre o que é o público e sobre qual é a opinião pública. A principal diferença entre esses meios é o consumo massivo, centralizado nas emissoras de telecomunicação de rádio e televisão versus o consumo individualizado e a-centrado que tende à segmentação, hibridização e diversificação de dados informacionais.

"Em resumo, a nova mídia determina uma audiência segmentada, diferenciada que, embora maciça em termos de números, já não é uma audiência de massa em termos de simultaneidade e uniformidade das mensagens recebidas. A nova mídia não é mais mídia de massa no sentido tradicional do envio de um número limitado de mensagens a uma audiência homogênea de massa. Devido à multiplicação de mensagens e fontes, a própria audiência torna-se mais seletiva. A audiência visada tende a escolher suas mensagens, assim aprofundando sua segmentação, intensificando 0 relacionamento individual entre o emissor e o receptor." (CASTELLS, 2000, p. 362-367).

A passagem da edição e da transmissão "fechada" de informação, para o acesso, edição e compartilhamento a-centrados no emissor, são responsáveis, não só por moldar a comunicação, o compartilhamento e a produção de notícias, mas também por propiciar novos ambientes socioculturais (RHEINGOLD, 2003), que operam os signos e as linguagens veiculadas nesse meio. Esse meio chamamos de cibercultura.

A realização em nível político da cidade interativa não tem a ver apenas com os computadores, mas é uma nova dimensão digital. Mais do que um novo meio de facilitar formas de comunicação e linguagem, ele altera os papéis desempenhados por instituições culturais, colocando o público e o usuário como agentes centrais da mobilidade. No entanto, Rob Van Kranenburg (2008), coloca a seguinte questão, essencial para começar a se pensar esse meio informacional:

"Se o ambiente se torna a interface, onde estão os botões? Ambiente requer inteligência, uma vez que as interfaces com os cidadãos acontecem em níveis muito superficiais de interatividade como quer a uma sociedade muito estável, muito calma e estéril. Qualquer alteração no sistema de inteligência, rodando em segundo plano e nos axiomas que compõem o ambiente, tem enormes conseqüências sobre os usuários destas interfaces, o que os torna impotentes, já que eles não têm idéia de como operar o que está rodando em segundo plano, muito menos consertar as coisas dão errado. Tal forma de inteligência ambiental pressupõe uma lógica totalizante e anti-democrática" (KRANENBURG, 2008, p.23) 
Aqui, Rob Van Kranenburg delineia um aspecto fundamental da cibridização: o ambiente, como interface informacional, será operado por quem? Sob quais perspectivas?

Embora práticas cada vez mais descentralizadoras desse tipo de produção aconteçam ao redor do mundo, como por exemplo as rede FAB-LAB, o Movimento Maker, os Laboratórios (Labs) colaborativos ou o mesmo a prática do Open Design em universidades e laboratórios. Há no entanto, que se verificar o impacto desses movimentos em relação ao monopólio da produção de tecnologias que proporcionam tais práticas. Visto que, a importância dessas práticas, permitem a difusão do conhecimento informacional, a descentralização da produção de novos dispositivos e o compartilhamento 'livre' da propriedade intelectual que recai sobre esses modos de produção.

\section{3.b - Delimitação conceitual: Espaço Virtual e Pós-virtual}

O neologismo cibercultura, especifica o conjunto de técnicas materiais e intelectuais, de práticas, atitudes, modos de pensamento, valores e práticas sociais que se desenvolvem juntamente com o crescimento do ciberespaço. (LÉVY, 1999, p. 17). O ciberespaço, por sua vez, designa esse meio de comunicação que surge da interconexão de computadores e que, no entanto, não se restringe à infraestrutura material da comunicação digital, mas abrange o universo oceânico de informações que ela abriga, bem como os seres humanos que produzem e navegam nesse universo.

Para Pierre Lévy (1999), o crescimento do ciberespaço é orientado por três princípios: a interconexão, a criação de comunidades virtuais e a inteligência coletiva. A interconexão, mundial ou local, é o princípio fundamental do ciberespaço, na medida em que sua dinâmica é dialógica. As comunidades virtuais "são construídas sobre afinidades de interesses, de conhecimentos, sobre projetos, em um processo mútuo de cooperação e troca" (LÉVY, 1999, p.127). Já a inteligência coletiva pode ser considerada a finalidade última do ciberespaço, pois ela descreve um tipo de inteligência compartilhada que surge da colaboração de muitos indivíduos em suas diversidades: "É uma inteligência distribuída por toda parte, na qual todo o saber está na humanidade, já que, ninguém sabe tudo, porém todos sabem alguma coisa” (LÉVY, 2007, p. 212). 
Manuels Castells chama essa configuração do Ciberespaço de "Espaços de Fluxos" e a define como uma organização material e temporal que permite práticas sociais simultâneas, sem necessariamente, haver uma continuidade territorial física. Composto e criado por diversos atores sociais que operam em rede (CASTELLS, 2000). Esta descontinuidade territorial, não sugere a fragmentação das práticas sociais em campos isolados de atuação: ou o espaço físico ou o ciberespaço, mas a complementação de um pelo outro.

Para André Lemos as práticas sociais da cibercultura, longe de serem neutras, envolvem territorializações e desterritorializações, tensionamento de saberes e forma de ocupar os espaços virtuais, revelam formas de potência, apropriação e poder dentro das redes. Uma verdadeira disputa por territórios informacionais, em vários níveis de produção e partilha. Temos portanto a produção de territórios híbridos resultantes das apropriações, físicas, conceituais, discursivas, políticas em constante tensão que se formam no ciberespaço e nos espaços cíbridos:

"Por territórios informacionais compreendemos áreas de controle do fluxo informacional digital em uma zona de intersecção entre o ciberespaço e o espaço urbano. 0 acesso e o controle informacional, realizam-se a partir de dispositivos móveis e redes sem fio. 0 território informacional não é o ciberespaço, mas o espaço movente, híbrido, formado pela relação entre o espaço eletrônico e o espaço físico. Por exemplo, o lugar de acesso sem fio em um parque por redes Wi-Fi é um território informacional distinto do espaço físico de um parque e do espaço eletrônico internet. Ao acessar a internet por essa rede wi$\mathrm{fi}$, o usuário está em um território informacional imbricado no território físico (político, cultura, imaginário, etc.) do parque, e no espaço das redes telemáticas." (LEMOS, 2008, p. 221).

Assim os territórios informacionais, longe de serem neutros, são políticos e revelam disputas territoriais em torno de agenciamentos informacionais.

O meio pós-virtual (BEIGUELMAN, 2013), não trata da superação do meio virtual, mas antes, da forma como este meio se estende para fora dos limites da telas digitais que adere, à qualquer superfície física, seja a partir de Qr-codes, etiquetas Rfid, aplicativos de realidade aumentada ou mesmo a utilização de metadados para extrair informações sobre meios físicos ${ }^{3}$. Portanto, não se trata de suplantar o meio virtual, mas de potencializá-lo, de incorporar suas práticas à outras práticas culturais.

\footnotetext{
${ }^{3}$ Um exemplo sobre a utilização de metadados, para levantar estatísticas precisas sobre o turismo em Nova York está no trabalho mais recente de Lev manovich: http://inequaligram.net; Nesse mesmo sentido há inúmeros artigos científicos sobre análises urbanas a partir de metadados.
} 
Até aqui, vislumbrou-se a formação de um cenário tecno-científico-informacional (SANTOS, 2000) que introduziu no mínimo, cinco conceitos diferentes para definir as práticas sociais em rede: Ciberespaço e Cibercultura (LÉVY, 1999), Espaços de Fluxos (CASTELLS, 2000), Territórios Informacionais (LEMOS, 2004) e Pós-virtual (BUEIGUELMAN, 2013).

Como vimos o ciberespaço designa o novo meio de comunicação que surge da interconexão de computadores, e inclui, além de sua infraestrutura material, o universo oceânico de informações que ela abriga, bem como os seres humanos que navegam e alimentam esse universo. A cibercultura abarca o conjunto de técnicas (materiais e intelectuais), de práticas, de atitudes, de modos de pensamento e de valores e as práticas sociais que se desenvolvem juntamente com o crescimento do ciberespaço. Estes dois termos se referem às práticas em rede, e portanto circunscritas ao espaço virtual. Os territórios Informacionais definem as práticas culturais e tensionamento políticos de apropriação deste meio e definição de zonas de adensamento no ciberespaço no espaço físico. Nesse sentido os territórios informacionais se inscrevem na cibercultura, como sendo parte política de sua ocupação, produção e partilha.

No entanto temos aqui, uma distinção entre as práticas sociais que se inscrevem apenas dentro do ciberespaço, e que portanto, operam no campo do virtual e da cibercultura e as práticas que integram o meio físico. Os espaços cíbridos como vimos anteriormente, são aqueles que hibridizam as práticas que ocorrem no ciberespaço, inscrevendo-as junto à dimensão física dos objetos, arquitetura, cidades, etc. e se diferenciam dos espaços de fluxos por serem uma concepção que não distingue a espacialidade física dessas duas esferas, os espaços cíbridos incorporam as mídias locativas se tornam um continuum das práticas sociais nesses espaços. Assumindo assim plenamente a condição de híbrido.

\section{4 - Mobilidade e locatividade no Espaço de Fluxos.}

A mobilidade sempre foi inerente tanto ao espaço construído quanto ao espaço urbano, os nômades, os imigrantes, as navegações, as colonizações e diversos outros tipos de mobilidade se operaram no centro das cidades ou na busca por novos espaços. Nesse século, a mobilidade adquire importância fundamental para a compreensão das 
dinâmicas cada vez mais aceleradas de que o meio informacional promove em meio as trocas, ao espaço urbano, as dinâmicas sociais.

No fim do século XIX o impacto da revolução industrial foi amplamente sentido na arquitetura e no urbanismo, a implantação da infraestrutura urbana de iluminação e energia associada aos novos modos fabris de produção e de trabalho, rapidamente transformaram os modos de viver e transformaram cidades em populosos centros urbanos. Sob a perspectiva das condições materiais que possibilitaram a aceleração temporal da vida nos centros urbanos, consideramos a mobilidade como um fator chave de entendimento: a mobilidade física das redes de transporte, a mobilidade comunicacional da invenções como o telégrafo, telefone, televisão e radio, a mobilidade dos fluxos financeiros e de produção fabril, como as linhas de montagem e e da bolsa de valores. Para André Lemos a cidade constitui-se, historicamente, como lugar de mobilidade e fixação, o espaço onde as práticas sociais se reconfiguram com a emergência das novas tecnologias de comunicações e das redes telemáticas.

No final do século XX, após a queda do muro de Berlin houve novamente um deslocamento em relação aos meios de produção juntamente com o desenvolvimento dos novos meios de telecomunicação. O capitalismo hegemônico ampliou mundialmente suas esferas de produção, com a formação dos blocos econômicos e, associada a essa formação, um novo meio tecno-científico-informacional (SANTOS, 2000) capaz de interligar estes centros pós-industriais à rede mundial de computadores.

Milton Santos descreve a construção ideológica da globalidade: "Fala-se em aldeia global para fazer crer que a difusão instantânea de notícias realmente informa as pessoas. A partir desse mito e do encurtamento das distâncias - para aqueles que realmente podem viajar - também se difunde a noção de tempo e espaço contraídos." ( Santos, 2000, p.18-19). Se compreende a sucessão de períodos de "modernização" interligados diretamente à sucessões de sistemas técnicos. Para ele é com o desenvolvimento e a incorporação dos sistemas tecnológicos informacionais nas formas de produção, que ele identifica a instantaneidade dos momentos e dos lugares, a universalidade e unicidade das técnicas. 0 desenvolvimento da indústria eletrônica, de computação e telecomunicações por meio de massivos investimentos na formação de infraestrutura, em contínuo desenvolvimento, englobou desde redes de computadores, banco de dados, multimídia, equipamentos de difusão por satélite, telefonia e serviços. A maior parte desta infraestrutura tem como ponto de convergência as redes 
telemáticas, que juntas formam as TIC's (Tecnologias da Informação e Comunicação).

As redes urbanas de transporte, gás, eletricidade e telecomunicações, estão para a infraestrutura das cidades Modernas, assim como as redes informacionais são um setor chave para compreender as metrópoles pós-industriais. As mudanças econômicas, sociais e das metrópoles capitalistas nos últimos 20 anos, suas estruturas políticas e dinâmicas socioculturais, estão no centro desse processo. Juntos, esses centros operam um conjunto de mercados financeiros globais abertos 24 horas, dominando os fluxos financeiros mundiais em estreita relação com as mídias pós-massivas.

Esse investimento na infraestrutura urbana é uma das mais profundas mudanças no desenvolvimento das redes urbanas desde o começo do século passado. 0 resultado é o movimento em direção ao gerenciamento de tempo real e ao desenvolvimento das redes de infraestrutura (LEMOS, 2004).

A mobilidade se agencia em meio aos territórios informacionais pois está em constante negociação entre fronteiras físicas e informacionais híbridas. A mobilidade atua portanto no espaço cíbrido, que integra por exemplo as redes de wi-fi e os espaços públicos, permitindo que os aparelhos móveis possam manter um fluxo contínuo de trocas de informação, nesse e no ciberespaço.

A questão que se coloca diante disso é, mesmo que invisivelmente demarcado, o espaço público passa a ser ocupado, privatizado e negociado a partir de redes pervasivas e de conexão e mobilidade. Logo no início da implantação dos sistemas de redes sem fio se tensiona constantemente a questão da propriedade, da ocupação o espaço público e a restrição ao acesso à esta rede que o ocupa. A invasão das redes Wifi no espaço público demonstram isso:

"Em agosto de 2002, o Slashdot publicou um texto denominado Starbucks vs Personal Telco Project (PTP), sobre uma batalha que foi silenciosamente travada na Pioneer Square, praça pública localizada em Portland, cidade mais populosa de Oregon (estado localizado na regiã o Noroeste dos EUA). Foi uma luta contra a obstrução do acesso público às redes sem-fio, mais especificamente contra o uso de sinais corporativos para derrubar nós que permitiam à comunidade o livre acesso à Internet. O PTP (como ficou conhecido o Personal Telco Project) havia duas conexõ es T1 com roteadores vendidos já configurados para instalação, o que permitia acesso sem-fio gratuito a qualquer um que levasse seu computador até a Pioneer Square."

(BUCKER-COHEN, 2009, p.11) 
Trata-se de uma nova forma de mobilidade que opera por fluxos de informação transitando pelos territórios informacionais e mesmo criando outros territórios informacionais, como vimos no caso da disputa por territórios wi-fi entre a Starbucks vs Personal Telco Project.

A mobilidade informacional portanto não está desatrelada da mobilidade física, ambas se imbricam e se potencializam pelos espaços físicos da cidade, formando novos lugares de trocas, novas espacialidades e territórios. Assim a mobilidade se expressa pela dinâmica de formação e trocas de informações que ocorrem através dos dispositivos móveis em trânsito pelo espaço urbano e suas zonas de conexão. 


\section{CAPÍTULO II}

\section{Mapeando de potências na arte e na arquitetura}

\subsection{Mapeamento em projetos de arquitetura}

Em um curto espaço de tempo o sistema de computadores e sua interconexão em rede se tornaram parte de um modo de se perceber, pensar e produzir os espaços da arte, do design, da arquitetura e do planejamento urbano. Proporcionando o que muitos autores chamam espaços de fluxos (CASTELLS, 2000) ou um como adotamos aqui, os espaços cíbridos (ANDERS, 2001), tão ou mais impactante e transformador para os modos de produção do capitalismo e da cultura contemporânea do que a primeira revolução industrial.

Igualmente, as implicações deste novo meio informacional, foram amplamente estudadas a partir de seu impacto e reformulação nos modos de produção da arquitetura e do design, o que suscitou uma verdadeira avalanche de neologismos, designações, metodologias de projeto e deslocamento discursivos destas disciplinas. Estes arquitetos, designers e artistas, vêm promovendo há quase 3 décadas, a revisão paulatina dos pressupostos mais arraigados da modernidade, tais como as formas de representação e linguagem das artes e da arquitetura, o surgimento de um espaço sígnico, híbrido entre o físico e o informacional, a incorporação da interatividade computacional no espaço físico da arquitetura, da cidade e da arte, etc.

Para este mapeamento selecionamos a primeira geração de arquitetos que incorporou o meio informacional como meio e método de projeto, experimentando, desenvolvendo e criando as bases epistemológicas para um novo meio informacional híbrido. Tal geração, marcada pelo experimentalismo, desenvolveu e desenvolve as bases epistemológicas para um meio que tende à hibridização entre o espaço 'físico' e o meio informacional. Este mapeamento coloca em questão as categorias espaciais que determinam o espaço 'físico' e o meio informacional e como estas categorias se relacionam em um meio híbrido. 
A princípio, Marcos Novak, na busca de conceituar um terceiro espaço, híbrido do cruzamento entre informação e arquitetura, elabora uma série de terminologias que transitam em torno da transdisciplinaridade destes espaços: Arquitetura líquida, Transarquitetura e Transmodernidade, entre outros. Lars Spuybroek, por sua vez, desenvolve o conceito de arquitetura maquínica, desenvolvendo metodologias para intercruzar corpo, paisagem, arquitetura e máquina, este último termo, foi utilizado por ele para designar toda arquitetura sensível e responsiva ao usuário. Greg Lynn busca um habitat embriológico capaz de formar um "organismo" que atue em simbiose com os seus usuários. Karl Chu, atua na elaboração do conceito de Arquitetura Genética, que se expressa através do desenvolvimento de meios capazes de incorporar e manipular códigos de DNA, como informação digital construtiva. Por fim elegeu-se o design de Pranav Mistry para abordar a transição deste espaço computacional da máquina para o corpo. Mistry, desenvolve um computador vestível, capaz de interagir com qualquer superfície física, transformando-a em superfícies significantes (um sistema de realidade mista $)^{4}$. Com isso aponta para a dissolução do modelo maquínico do computador e sua integração nos espaços dos objetos, das edificações, das cidades e dos corpos.

\subsection{1 - Relações Internas das Obras}

\subsection{1.a - Transarchitecture | 2000 | Marcos Novak ${ }^{5}$}

Palavras-Chave: Arquitetura experimental, Transarquitetura, Arquitetura Líquida, Transvergência

\section{Descrição}

Marcos Novak faz parte de uma geração de arquitetos, designers e artistas gráficos que se formaram com a predominância do código digital sobre a produção de imagens e modelos arquitetônicos, os chamados Natural Born CAD designers (PERBELLINI e PONGRATZ, 2000). Pesquisador experimental da arquitetura virtual, Novak traça estratégias metodológicas e conceituais para determinar de que forma esse novo espaço se constitui como 'corpo' informacional próprio. De fato, uma característica singular do

\footnotetext{
${ }^{4}$ ver glossário;

${ }^{5}$ Marcos Novak é arquiteto, artista, compositor e teórico, emprega algoritmos para projetar ambientes inteligentes reais, virtuais e híbridos. Se descreve como transarquiteto e tem como objetivo expandir a definição de arquitetura incluindo espaço informacional em sua tessitura. Novak é professor do Departamento de Arquitetura e Urbanismo na Universidade da Califórnia (UCLA), é diretor-fundador do Laboratório para Ambientes Virtuais Imersivos e do Programa de Pesquisas Avançadas na Escola de Arquitetura da Universidade de Austin no Texas e membro da World Technology Network;
} 
pensamento de Novak é a proposição de que o ciberespaço ${ }^{6}$ se constituiria como um espaço arquitetônico autônomo, dotado de singularidades que o colocariam na condição de um novo espaço arquitetônico.

Para explorar a integração entre os espaços físico e o virtual Novak considerou necessário introduzir novos termos em seu trabalho, para descrever as mudanças epistemológicas que a tecnologia digital tem provocado no discurso da arquitetura, dessa forma ele cunha os termos Transarquitetura e Transmodernidade (ZELLNER, 2000, p.128), que buscam traduzir a relação de tranversalidade e contaminação entre o ciberespaço, a arquitetura e a cibercultura.

A transarquitetura, no entanto, trata de uma terceira condição, uma qualidade espacial que emerge da sucessiva diluição entre a oposição de definições binárias como hardwares e softwares ${ }^{7}$, masculino e feminino, real e virtual:

"O ciberespaço por si, nunca se limitou a realidade virtual, mas tem a ver com a nossa invenção de um espaço pervasivo e 'inescapável', um espaço completamente entrelaçado com a cultura... Me deparei com a idéia de 'transarquitetura' como uma forma de tecer abordagens mais amplas, e a idéia de eversão como meio de transição entre dentro e fora do ciberespaço. Transarquitetura é um super conunto que contém e extende a arquitetura líquida. Se arquitetura líquida tem a ver com com a observação da variação líquida como uma peça chave do nosso tempo, a transarquitetura foca nos efeito dessa variabilidade. Nós transitamos da espacialização das disciplinas para a multidisciplinaridade, interdisciplinaridade e agora a transdisciplinaridade. (NOVAK apud. ZELLNER, 2000, p. 130, tradução nossa).

O prefixo trans não implica apenas a aceitação da combinação dos opostos, mas uma condição de perpétua transformação, que constantemente nos confronta com o que podemos chamar de um "Alien artificial" um fruto 'estranho' de nossa própria criação. Este constante confronto com um fruto estranho desta criação é a assinatura da nossa própria forma de modernidade ou Transmodernidade. Portanto a transarquitetura é a expressão dessa transmodernidade em relação a constituição de um espaço próprio, também conhecido como ciberespaço. Em um sentido mais tangível a arquitetura

\footnotetext{
${ }^{6} 0$ neologismo 'ciberespaço' surge a partir da obra de ficção científica de Willian Gibson entitulada Neuromance em 1984. 0 termo designa o novo meio de comunicação que surge da interconexão mundial dos computadores e especifica, não apenas a infra-estrutura material da comunicação digital, mas também o universo de informações que ela abriga, assim como as pessoas que navegam e alimentam esse universo. (LÉVY, 2000).
}

${ }^{7}$ ver glossário de termos; 
líquida tem a ver com o design algorítimico computacional, enquanto a transarquitetura tem a ver com todo o espectro do que pode ser chamado de nova tectônica, ou seja, a concepção algorítmica, a prototipagem rápida, fabricação robótica, habitações interativas, telepresença, telecomunicação e a conexão virtual, criando um novo espaço contínuo: local-físico e virtual-não-físico. (ZELLNER, 2000, p. 130)

\section{Objetivos}

A transarquitetura investiga as relações de contaminação entre o espaço físico e o espaço virtual, concebe ainda a transarquitetura como a expressão dessa nova qualidade que surge entre o intercruzamento dos aspectos da cibercultura ou transmodernidade e estuda o desenvolvimento de uma nova epistemologia referente a esse 'estranho fruto de nossa concepção' ou como ele mesmo nomeia: o Alien. É através desse terceiro elemento, a transarquitetura, que Novak pôde 'suavizar' conceitualmente a rígida distinção entre os espaços virtual e físico, a fim de integrar as tecnologias do espaço virtual aos ambientes arquitetônicos.

\section{Metodologia, tecnologias envovidas e reprodutibilidade técnica da obra}

Para Novak (1998, p. 86), a contemporaneidade é caracterizada por cinco graus de virtualidade:

- luz e sombra - projeções de presença e ausência, espelhos;

- amostragens e estatísticas - construções da continuidade para a descontinuidade,

- conotação para denotação: cinema, televisão, som digital, conversões analógicodigital e digital- analógico;

- inversão - computação e epistemologia, simulações, programas gráficos, efeitos especiais;

- imersão - alteração, ciberespaço, realidade virtual, lançar o real no virtual;

- eversão - lançar o virtual no real;

E neste contexto, ele considera o termo "transarquitetura" como ampliação do ofício do arquiteto, pela união de todas as possibilidades colocadas para a arquitetura nos tempos atuais: a concepção algorítmica (morfogêneses), modelagem numérica (prototipagem rápida), construção robotizada (novas tectônicas), habitação interativa (espaço inteligente), telecomunicação instantânea (pantopicon), informações imersivas (arquiteturas líquidas), sociabilização não-local (domínio público não-local) e eversão virtual (transarquiteturas). 
Trabalhando com o intercruzamento entre mídias e tecnologia, o espectro espacial da Transarquitetura inclui o design gerado a partir da programação em linguagem computacional e explora as concepções matemáticas do espaço e da música (espaçotempo) derivado das operações quadridimencionais da computação.

Sua obra é configurada nos interstícios do físico, do virtual e do interativo que transmutam modelos computacionais em superfícies tectônicas, lançando as bases do que hoje, há duas década depois, é amplamente reconhecido como linguagem paramétrica e generativa.

\section{Modos de extroversão}

A extroversão da transarquitetura busca se expandir rumo a uma interação fluida, entre espaço virtual e físico, expressa sob a forma de habitats imersivos, eversivos, interativos e hiperconectados estabelecendo uma relação de simbiose entre usuário e obra. Ainda que seja a princípio realizada para o espaço virtual as obras de Marcos Novak são experimentadas a partir de protótipos que desenvolvem interatividade Imagens $^{8}$

\footnotetext{
${ }^{8}$ Imagens disponíveis em: http://www.mat.ucsb.edu/ marcos/transvergence.pdf. Acesso em:11/11/2015.
} 

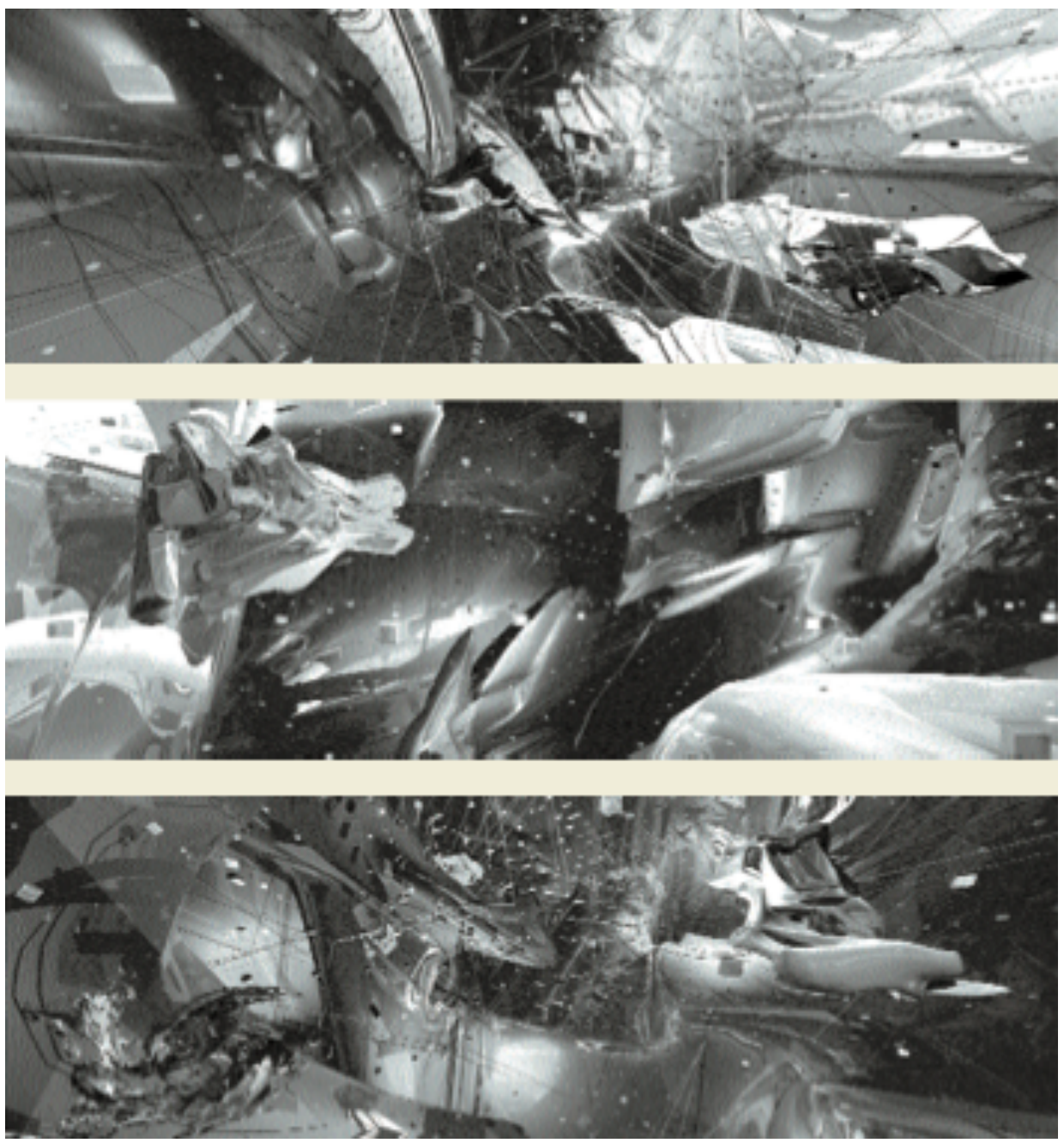

Fig. 1 - Diagramas de transvergência9

\subsection{1.b - NOX: Machining Architecture | 2004 | Lars Spuybroek \& NOX ${ }^{10}$}

Palavras-Chave: Arquitetura experimental, interfaces dinâmicas, topologia e variação

\section{Descrição}

Para este mapeamento elegemos especificamente dissertar sobre o Pavilhão FreshH20 Expo, por nos parecer uma síntese da obra experimental de Lars Spuybroek sobre o processo de convergência entre arquitetura e espaço informacional. Trata-se de

\footnotetext{
9 os Diagramas de transvergência partem da 'correção tática' ou interpolação matemática entre divergência e convergência, trata-se de uma modelagem feita para explorar espacialmente as ideias de 'equilíbrio potuado' e 'exaptação' do biólogo evolutivo Sthepen Jay Goulds, que defende que nós, através da tecnologia, estamos criando nosso próprio desenvolvimento evolutivo. (NOVAK, 2002, p.68, tradução nossa) ${ }^{10}$ Lars Spuybroek graduou-se em arquitetura na TU Delft no início da década de 1990, quando fundou junto ao seu sócio Maurice Nio o estúdio NOX em Rotterdam, onde atuou até o fechamento do estúdio em 2010. Spuybroek foi professor titular em Design Digital na Universidade de Kassel, Alemanha; professor visitante na Universidade de Columbia, na Escola Superior de Arquitetura em Barcelona e na Architectural Association de Londres. Atualmente, é professor titular no Instituto de Tecnologia da Georgia - Georgia Tech, em Atlanta, como professor de projeto.
} 
um projeto emblemático para esta análise, porque promove a reunião de questões seminais, desenvolvidas no decorrer das obras seguintes, e demonstra a preocupação com o desenvolvimento da formalização metodológica de sua Arquitetura Maquínica (Machining Architecture).

Embora as obras de Lars Spuybroek sejam caracterizadas principalmente pelo experimentalismo e a pela diversidade formal, como forma de questionamento radical dos princípios cartesianos da linguagem arquitetônica, esta diversidade pode ser estudada a partir de três eixos dominantes em sua prática:

- O corpo como participante ativo na transformação do espaço e das durações arquitetônicas, segundo a perspectiva fenomenológica de Spuybroek;

- A revisão metodológica das práticas projetuais consagradas pela tradição moderna e a proposição de um novo 'método' maquínico;

- A incorporação de linguagens digitais no espaço arquitetônico e a utilização da modelagem digital como linguagem dinâmica que adquire o estatuto da obra;

Um olhar mais atento ao conjunto de sua obra mostra que sua ênfase metodológica se dá em torno do desenvolvimento de dispositivos maquínicos que buscam revisar a tradição moderna:

\begin{abstract}
O Pavilhão da Água Doce, localizado na plana paisagem da itha artificial da costa holandesa [...], é o primeiro edifício-bolha verdadeiramente interativo, uma versão construída da Endless House de Kiesler, onde nenhuma superfície é completamente horizontal e piso, paredes e cobertura ondulam continuamente uns nos outros. Agora é a experiência do corpo que determina a forma [...] o pavilhão possui um conjunto de sensores que respondem aos movimentos do corpo. Não há duvidas de que o edifício ativa o corpo tanto visualmente quanto cinestesicamente [...] Agora a prótese cerca todo o corpo enquanto ele se move, pula ou desliza pelo edifício, o corpo aciona sons e músicas, ou pequenas ondas de água [...] Então, se trata de uma arquitetura eletrônica e háptica - um desejo de muitos arquitetos por muitos anos - finalmente alcança seu primeiro estágio de realização. (JENCKS, 2002, apud. FERREIRA p. 234).
\end{abstract}

No final dos anos de 1990, o pavilhão da Água (FreshH2O Expo) foi encomendado pelo Ministério de Obras e Controle de Águas holandês este projeto integra um projeto maior de engenharia: o Projeto Delta, uma grande obra de construção de diques e comportas para o controle do nível da água da costa holandesa. Espacialmente, o Pavilhão da Água é o primeiro edifício a combinar um interior interativo e imersivo, 
envolvendo os participantes com uma estrutura geométrica contínua onde os pisos se transformam em paredes e as paredes em tetos (SPUYBROEK, 1999) ${ }^{11}$.

O interior da exposição é, em parte, baseado manipulação dos estados sólido, líquido e gasoso da água como material arquitetônico: o congelamento de uma parede, sprays de névoa, chuva artificial e jatos de água e, em parte, interações eletrônicas feitas em tempo real feitas por biosensores, inovadoras para a época (1994-1997). O edifício contém uma ampla gama de sensores através do qual os visitantes podem alterar os sons, luz e projeções que alteram completamente a atmosfera interior da obra, que claramente prioriza o aspecto sensória da arquitetura de Lars Spuybroek.

\section{Objetivos}

A obra de Spuyborek junto ao estúdio NOX se caracteriza pelo incessante desenvolvimento e experimentação de novas metodologias projetuais, bem como pelo questionamento radical das práticas legitimadoras da arquitetura moderna. De fato, Spuybroek se insere em uma geração de arquitetos holandeses que, em meados da década de 90, assimilou a modelagem computacional em sua prática. Esta geração, denominada "digerati"12 por Feiress (1997), caracterizou-se por reinventar novas estratégias de projeto, contrapondo-se a qualquer idioma estilístico predominante na arquitetura da época. (FERRANTE, 2013, p.7).

"Nós estamos experimentando uma extrema liquidização do mundo, de nossa linguagem, de nossos gêneros, de nossos corpos (...) estamos entrando em uma era onde todas as coisas se tornam mediadas, onde todo espaço é fundido com sua representação nas mídias digitais e onde toda forma é mesclada com informação". (SPUYBROEK apud. ZELLNER, 2000, p. 112, tradução nossa).

Como os demais arquitetos de sua geração, Lars Spuybroek/NOX recusa a fórmula moderna: forma segue função. No entanto é através do novo meio digital que a complexidade formal e geométrica de suas experimentações ganha corpo e abre novos

\footnotetext{
${ }^{11}$ Disponível em: http://www.nox-art-architecture.com. Acesso em: 01/10/201.

12 "Digerati - neologismo para referenciar-se a uma "elite digital", grupo de pessoas na vanguarda em determinadas disciplinas quanto ao uso do computador ou ferramentas digitais. "Digerati" funciona como equivalente de literati, referente aos intelectuais e estudiosos do Renascimento. Denominado como tal por críticos e leitores de seu trabalho, 0 próprio arquiteto se reconhece parte da geração: “Entre a jovem geração de arquitetos digerati, Lars Spuybroek, e seu estúdio em Rotterdam, está entre os poucos que teve projetos concluídos e construídos. Antes do advento do poder de processamento em larga escala, modelagem digital e processo de fabricação orientada por sistemas CAD. As estranhas estruturas de Nox talvez fossem inconcebíveis." (FEIRESS, 1997 apud. FERRANTE, 2013, p. 77).
} 
caminhos tanto em termos de produção, quanto para o pensamento de projeto generativo e computacional. Por essa inserção contextual, a arquitetura de Spuybroek foi e ainda é, conhecida pelos rótulos de virtual, digital, e suas variações (JENCKS, 2002, p. 210).

\section{Metodologia}

Spuybroek desenvolve cinco etapas do seu método projetual, cada uma concebida como etapas de uma metodologia maquínica. Ele estabelece, como fio condutor a oposição entre as noções de contração e expansão:

- A primeira máquina introduz a metáfora da "perfuração" (drilling) e insere a noção de tela digital no sistema mente-mão a fim de se libertar de lógicas analógicas e emular, no computador o comportamento de sistemas dinâmicos, de difícil ou impossível visualização sem as ferramentas digitais;

- A segunda máquina leva a um processo de abstração e síntese (abstracting: inserting an interface at the start of a project). A partir do modelo tridimensional que foi constituído como interface digital, se projetam imagens analógicas referentes ao tema do projeto e se estabelece um ponto de partida que transpõe as técnicas diagramáticas de projeto para sua condição digital. Assim as imagens se tornam superfícies informacionais capazes de todo tipo de deformação estrutural, inicia-se então a formação da geometria no sentido autopoiético do projeto.

- A terceira máquina (surfacing: inserting a plane in architecture) converte a tridimensionalidade do modelo produzido na segunda etapa em superfícies planas que serão impressas. Este procedimento se situa conceitualmente, entre os processos de contração e expansão, retendo do primeiro, os componentes necessários à emergência do segundo.

- Como consequência, a quarta máquina opera ao nível da estrutura (structuring:: inserting a surface in the realm of volume), dá volume à superfície diagramada na etapa anterior e implica não somente um volume gerado pela superfície, mas densidade definida pelas características dos materiais.

- Completando o ciclo, a quinta máquina opera a modelagem (modeling: inserting a diagram on the level of built structures), que estabelece os parâmetros definidores da construtura; agrega no processo as diferentes dimensões anteriormente exploradas (o 
sítio, o programa, as escalas, as imagens) e revela o todo da materialidade e da estética dessa nova arquitetura digital.

Embora esse desdobramento metodológico de um pensamento-máquinico seja amplamente difundido com as atuais plataformas de projeto, modelagem, animação e impressão 3D, é nessa época que se estabelecem os princípios de interação da interface virtual com o espaço físico da obra. Atualmente com as máquinas de impressão 3D e 4D (aquelas que incluem a articulação de peças produzindo movimento estrutural) ${ }^{13}$ este processo foi automatizado nos meios de produção desde sua concepção diagramática abstrata (referentes à primeira máquina) até a etapa de estruturação material da obra (quinta-máquina).

\section{Tecnologias Envolvidas, Reprodutibilidade tecnológica da obra}

A metodologia maquínica de Spuybroek sintetiza cinco etapas projetuais, cada uma concebida com tecnologias e metodologias muito específicas, amplamente difundidas nos dias atuais:

- primeira máquina: a relação de interface entre olho-mão/mouse-tela/monitor e programas de diagramação e modelagem bidimensionais e tridimensionais;

- segunda máquina: uma operação abstrata que consiste em modelagem tridimensional do projeto através de cálculos numéricos e algorítimos baseados principalmente em programas como CAD (Computational Aided Design) ${ }^{14}$;

- terceira máquina: envolve o processo de impressão e planificação ortogonal da volumetria gerada em CAD;

- quarta máquina: processo de renderização e tratamento de imagens no modelo tridimensional;

- quinta máquina: produção material da obra que no caso específico do pavilhão da água doce, é aquipado com sensores - táteis, de luz e de presão - que criam uma interface entre usuário e o edifício, que se modifica de acordo com as ações dos usuários.

\footnotetext{
${ }^{13}$ mais informações sobre o processo de impressão 4D disponíveis em: https://www.ted.com/talks/skylar tibbits the emergence of 4d printing?language=pt-br Acesso em: 2/10/2015;

${ }^{14}$ Informações mais detalhadas sobre o Computational Aided Design disponível em: http://www.autodesk.com.br/solutions/cad-software. Acesso em: 2/10/2015;
} 


\section{Modos de extroversão}

$\mathrm{Na}$ arquitetura de Spuybroek, o corpo é o principal meio de relação e modificação da obra. Este projeto estimula a perda de referenciais e estimula o movimento e interação dos usuários e relação à obra; Spuybroek argumenta que "isso só será possível quando descobrirmos uma relação mais interativa e contínua entre arquitetura e corpo, tanto em termos do projeto quanto em termos da forma edificada" (SPUYBROEK apud. FEIRESS, 1997, p.21). O arquiteto privilegia o corpo e a experiência ativa de exploração opondo-se ao que ele definia como a passividade da arquitetura tradicional, que consolidou um sujeito estático e a experiência visual da arquitetura. Assim ele propõe uma revisão das características arquitetônicas típicas dos consagrados espaços cartesianos e da geometria euclidiana, para tornar o espaço uma experiência de imersão interativa.

O espaço do edifício, por se interativo, se encontra em constante modificação, não se trata de um objeto acabado e não há portanto uma definição estática de seu conjunto que possa ser percebida e definida antes da experiência imersiva do corpo. É de acordo com a interação do corpo com a obra que o edifício se constitui como um todo inseparável. 0 corpo do usuário é lido aqui como um agente de construção do espaço que dilui a oposição sujeito e objeto da arquitetura.

\section{Imagens $^{15}$}

\footnotetext{
${ }^{15}$ Imagens disponíveis em: www.teses.usp.br/teses/disponiveis/16/.../sabela Ferrante Dissertacao.pdf. Acesso em: 01/10/2015_Créditos: Isabela Paiva Gomes Ferreira
} 


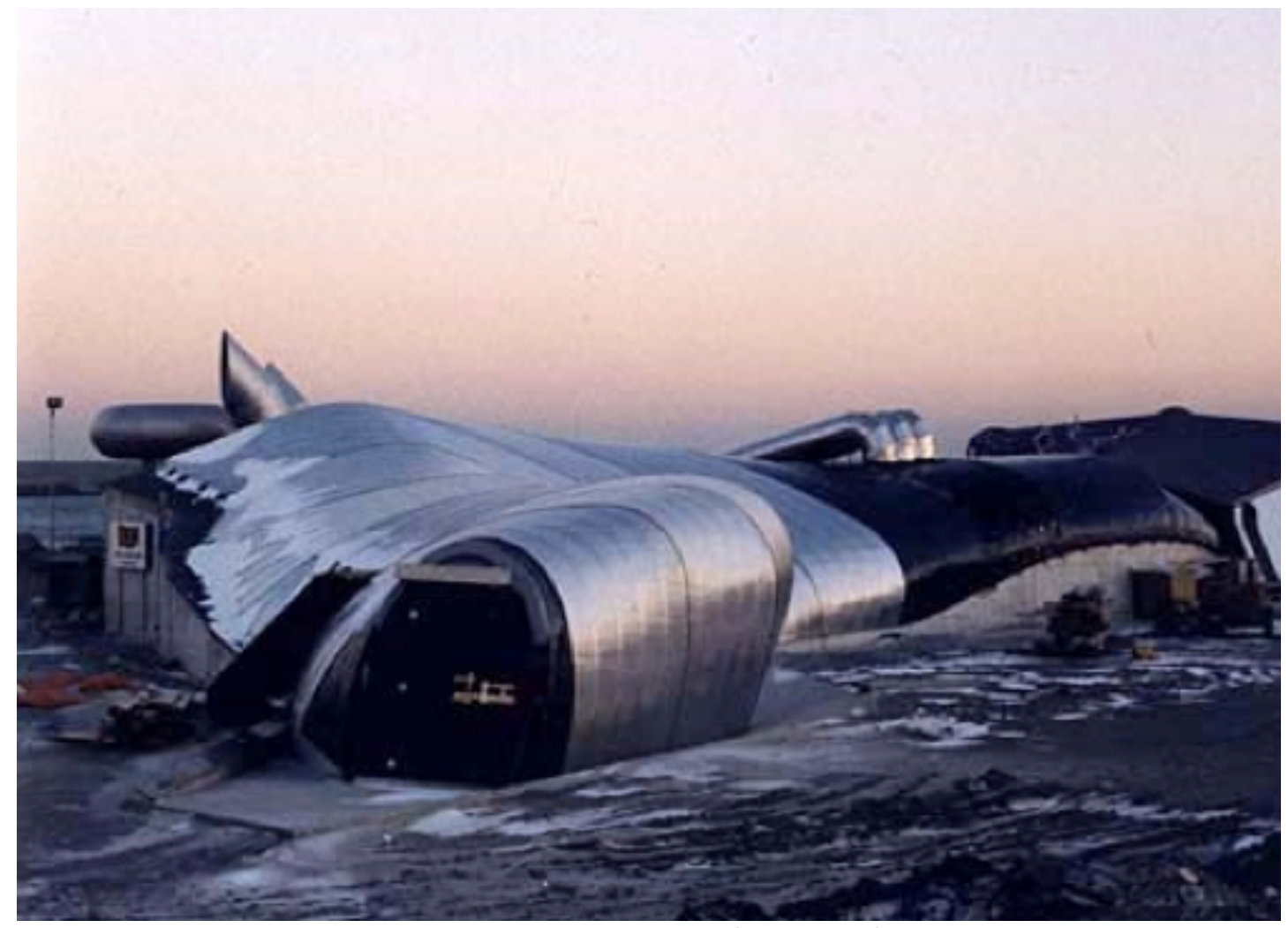

Fig. 2 - Pavilhão da água: construído por ocasião da expo fresH2O eXPO
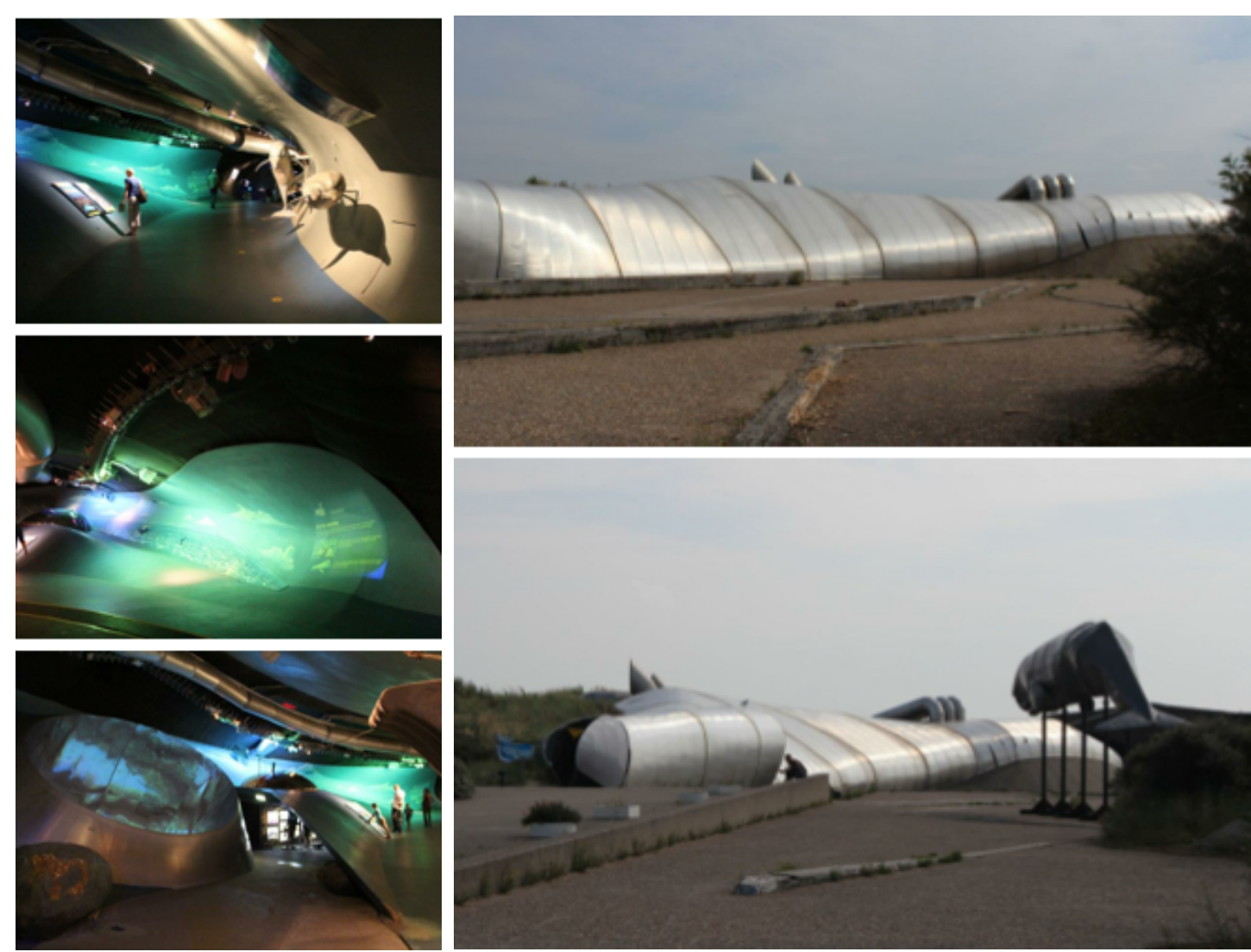

Fig. 3,4,5 (à esquerda, de cima para baixo) - Vistas internas do Pavilhão da Água Doce construído por ocasião da exposição fresH2O eXPO. Fig. 6 e 7 (à direita de cima para baixo) - Vistas externas; 


\subsection{1.c - Embryological House | 1998 | Greg Lyn ${ }^{16}$}

Palavras-Chave: Arquitetura experimental, interfaces cognitivas, animation form

\section{Descrição}

"Constructed by and inside of flows, Greg Lynn 'animate forms' are designed within unstable realm of variable, fluctuating dynamics and movements, leading away from an architecture of stasis to one evolution." (ZELLNER, 2000. p.136) ${ }^{17}$

A Casa Embriológica (Embryological House) pode ser descrita como uma estratégia de invenção do espaço doméstico que envolve questões contemporâneas sobre a identidade, repetição, diferença, produção e montagem flexíveis. Acúmulo, conservação e transmissão informacional sobre as estruturas e superfícies arquitetônicas.

O projeto da Casa Embriológica (Embryological House) envolve o intercruzamento de modelagem numérica digital e protótipos de materiais sensíveis, capazes de se transformar estruturalmente e responder a estímulos externos do ambiente e de seus usuários.

Composta inicialmente por 2.048 painéis flexíveis de madeira, polímeros ou aço. Cada um desses painéis possui formato, textura e dimensão diferentes e todos são interligados de tal maneira que qualquer ação sobre um painel se distribua sobre todos os outros, transformando toda a estrutura. Para cada painel Lynn adotou cálculos variáveis, fixando limites máximos e mínimos de transformação, que vinculados entre si, atribuem ao todo da estrutura infindáveis possibilidades de respostas ao ambiente, assimilando em sua forma níveis de informação e complexidade crescente.

\section{Objetivos}

Greg Lynn delineia na Embryological House alguns pressupostos que vão permear suas futuras obras como e pesquisas como no texto, Animate Form:

\footnotetext{
${ }^{16}$ Greg Lynn é arquiteto no estúdio Greg Lynn FORM, professor de arquitetura na Universidade de Artes Aplicadas de Viena (IOA), Escola de Artes e Arquitetura da Universidade da Califórnia (UCLA) e professor visitante na Escola de Arquitetura de Yale. Foi Ganhador do Golden Lion, prêmio da bienal de arquitetura de veneza (2008). Autor de livros como Folds, Bodies and Blobs: Collected Essays (La Lettre volée, Brussells), Form Animate (Architectural Press Princeton, New York) e outros. Fonte: http://www.studiolynn.at/people/greg-lynn.html. Acesso em: 14/09/2015;
}

17 N. do a.: "construídas por e dentro de fluxos, as 'Formas Animadas' de Greg Lynn são projetadas dentro do reino instável da variável, de dinâmicas e movimentos flutuantes, levando para longe de uma arquitetura da stasis (estabilidade) para uma evolução" 
- Repensar os meios de produção da arquitetura na era pós-industrial, avançando no discurso arquitetônico contemporâneo sobre as linguagens de representação dominantes;

- Formular uma crítica à compartimentalização funcional do modelo modernista, criando protótipos flexíveis e orgânicos capazes de responder às infinitas formas de interação;

- Ampliar a interface entre as disciplinas: biologia, espaço digital informacional e o 'modelo' arquitetônico, tensionando as bordas dessas disciplinas;

- Pensar a arquitetura em termos de aquisição, conservação e transmissão informacional, através da animação e interatividade.

\section{Metodologia, Meios De Produção e Tecnologias Envolvidas}

O projeto digital empregou um rigoroso sistema de limites geométricos nãoeuclidianos, que geraram modelos de variações infinitas. Associados à modelagem digital 3D via CAD (Computer Aided Design) nos programas Microstation e Maya. Cada painel possui forma, tamanho e textura diferentes e são projetados segundo um princípio de animação constante (ZELLNER, 2000. P. 139). A fabricação dos painéis foi prevista em madeira, polímero ou aço, com modelagem e cortes controlados por computadores robóticos e máquinas de corte com jato de água de alta pressão.

A variação das superfícies internas e externas são praticamente infinitas, mas em cada variação há sempre um número constante de painéis interligados em uma relação proximidade. $\mathrm{O}$ volume é definido como uma superfície macia e flexível de curvas ao invés de um conjunto fixo de pontos rígidos. Por isso ao invés de cortar janelas e abrir portas, uma estratégia alternativa de aberturas foi inventada: cada incisão, abertura ou concavidade é integrada à superfície que se abre e pode voltar a se fechar.

\section{Reprodutibilidade tecnológica da obra}

Esta obra de certa forma se antecipa em questões que foram colocadas com o surgimento das impressoas 3D e 4D de fabricação digital (FAB-Labs), no entanto na época de sua elaboração a casa embriológica dispôs da criação de um protótipo com aço, com modelagem e cortes controlados por computadores robóticos e máquinas de corte a jato de água de alta pressão. 
A elaboração dos modelos e cálculos geométricos foram feitas a partir de programas que existem ainda hoje: Maya e Microstation, porém adotando cálculos de modelagem e interação mais sofisticados.

\section{Modos de extroversão}

Trata-se de um projeto conceitual realizado em plataforma digital, modelado para prever interatividade entre obra e usuário e a transformação sistêmica do conjunto de painéis através da manipulação direta do modelo.

Imagens ${ }^{18}$ :

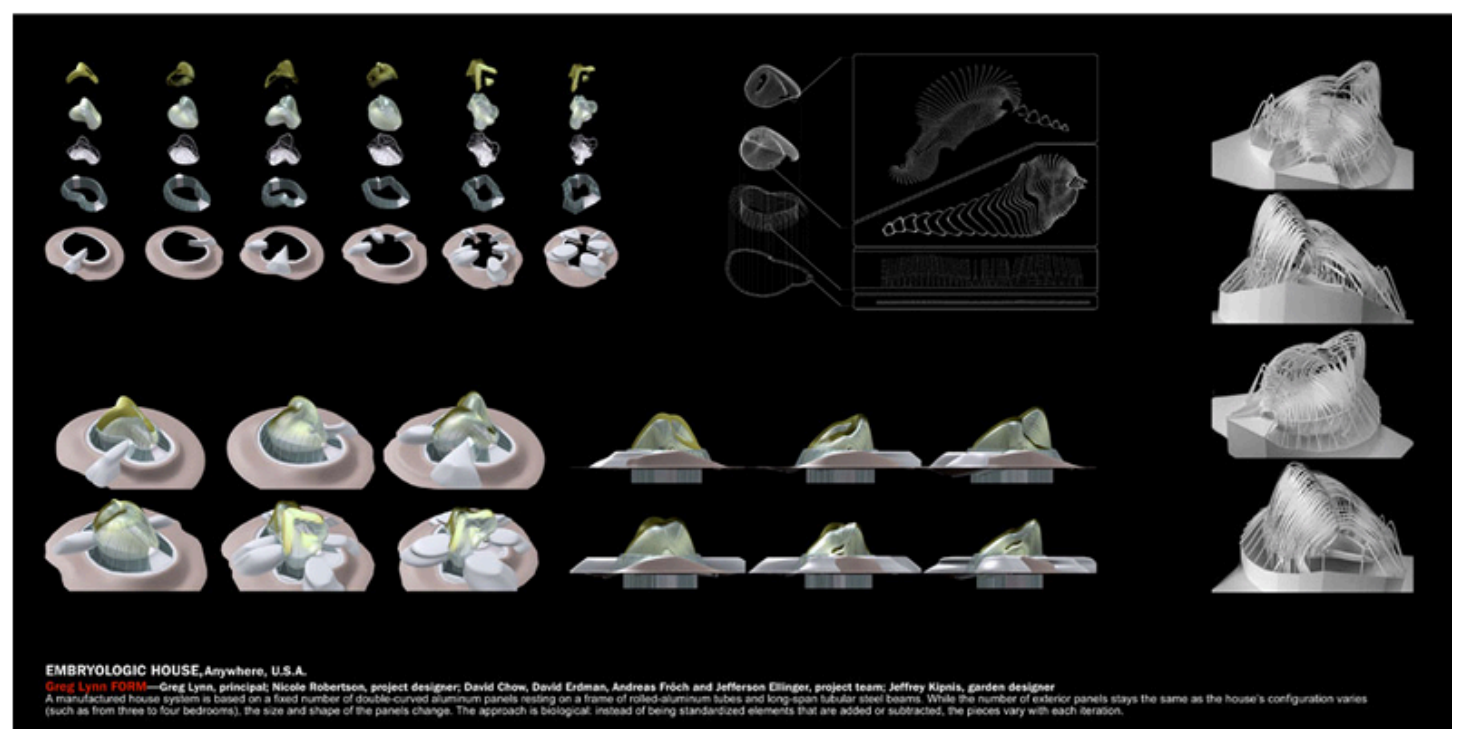

Fig. 8 - Plano de evolução da Casa Embriológica - Ebriological House

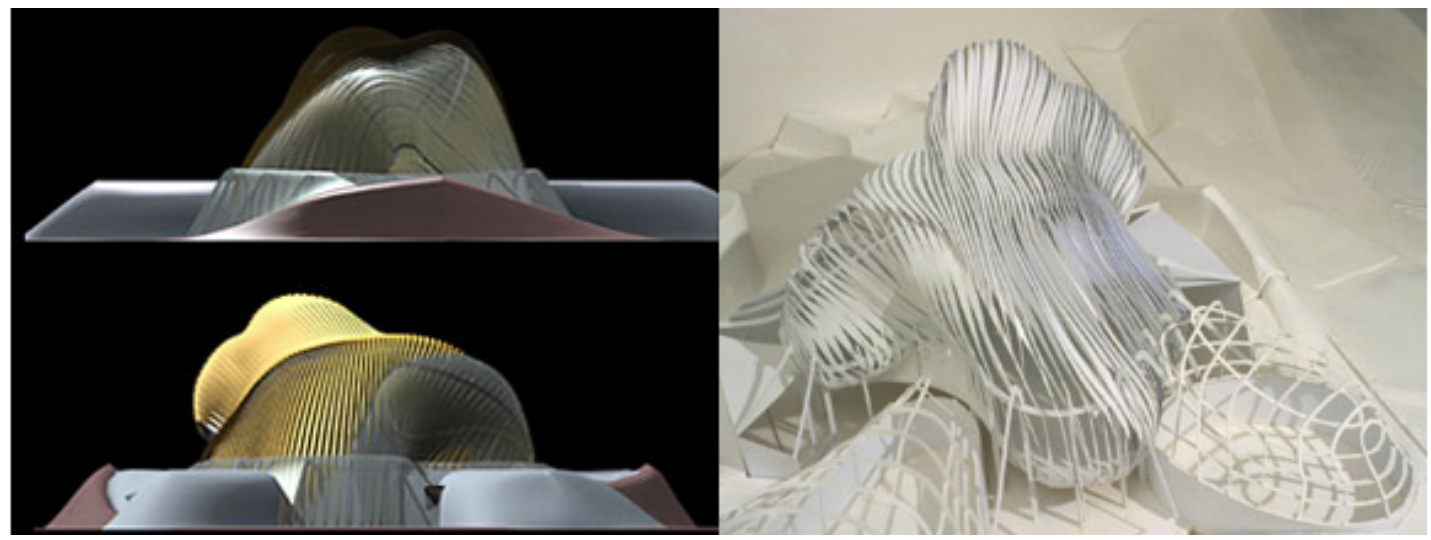

Fig. 9 - Modelo tridimensional de membrana flexível

\footnotetext{
${ }^{18}$ Imagens disponíveis em: http://www.docam.ca/conservation/embryological-house/GL3ArchSig.html. Acesso em: 21/09/2015.
} 

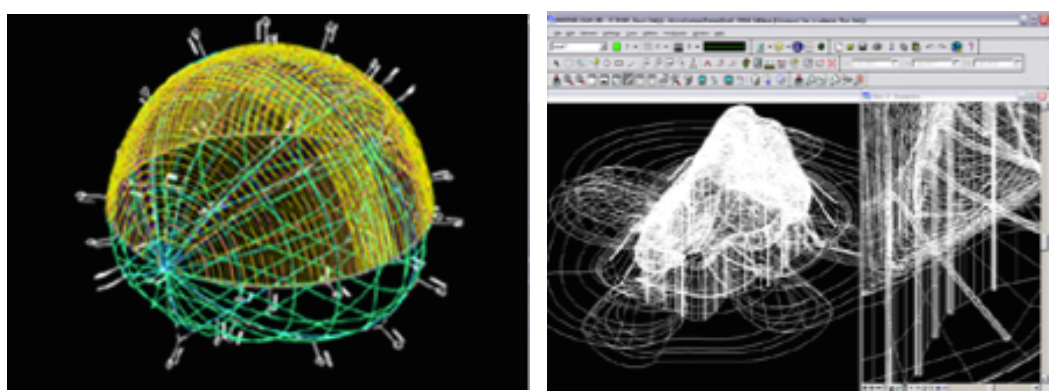

Da esquerda para direita: Fig. 10 - visualização da forma primitiva simétrica que funciona como base inicial para as interações (criada no programa Microstation); Fig 11 - Desenvolvimento do modelo 3D interativo da Casa Embriológica (criado no programa

Maya)
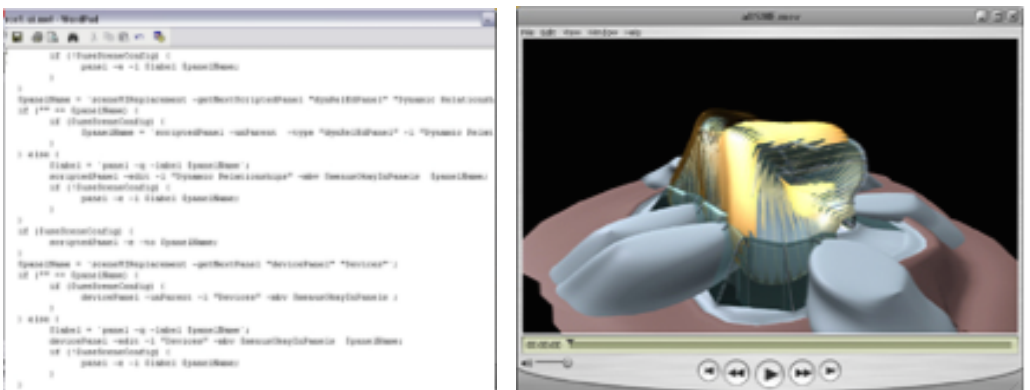

Da esquerda para direita: Fig. 12 - Algoritimos de interatividade; Fig.13 - modelo interativo;

\subsection{1.d - Genetic Space | 2000 | Karl Chu ${ }^{19}$}

Palavras-Chave: Arquitetura genética, vida artificial, interfaces cognitivas

\section{Descrição}

"O espaço genético é o domínio de mundos possíveis, gerados e mitigados através do tempo pelos phylum maquínicos. Esta é a zona de emissão das radiações de descompressão da realidade, uma explosão super-crítica de algoritmos genéticos latentes, com a capacidade de se libertarem para o espaço genético. Não é um receptáculo passivo, mas um espaço evolutivo ativo, dotado de propriedades dinâmicas e conhecimento da paisagem epigenética."(BRATTON apud. CHU, 2008, p.2)

Genetic Space é um conceito que funciona como dispositivo, ou um conceito maquínico, em que Karl Chu pesquisa e fundamenta a engenharia genética como meio para realizar a plena integração entre o espaço virtual e o espaço arquitetônico. 0 autor adota o modelo matemático da Máquina Universal de Alan Turing (1936), para

\footnotetext{
${ }^{19}$ Karl Chu é diretor da Metaxy, estúdio de arquitetura; Professor na Escola de Arquitetura do Instituto Pratt; Fundador e diretor do Instituto para a arquitetura genética no GSAPP, Universidade de Columbia, Nova Yorque; Co-diretor do Programa de Arquitetura Biodigital ESARQ, na Universitat Internacional de Catalunya, em Barcelona; Disponível em: https://www.pratt.edu/faculty and staff/bio/?id=kchu999 Acesso em: 28/09/2015.
} 
conceituar uma mônada ${ }^{20}$ informacional onde uma nova espacialidade arquitetônica seria constituída de materialidade informacional, resultado da hibridização entre os filos (phylum) orgânico e um novo filo: o maquínico, que define-se mais adiante.

Karl Chu propõe que a engenharia genética será capaz de intercruzar a materialidade informacional do código genético (phylum orgânico) e do código binário computacional, que ele denomina como o novo filo: o phylum maquínico, uma 'segunda natureza' constituinte do Espaço Genético. Esta convergência seria capaz de modificar radicalmente a forma de perceber e conceber a natureza do espaço arquitetônico, produzido a partir da manipulação de códigos informacionais orgânicos e não-orgânicos.

Assim o Espaço Genético seria capaz de formular as bases para uma arquitetura material auto-regulável e dinâmica e ao mesmo tempo artificial, orgânica, tensionando as fronteiras destas conceituações.

\section{Objetivos}

Karl Chu busca lançar a base teórica para fundamentar os processos de produção de um novo meio informacional (Genetic Space), resultante da hibridização entre o filo orgânico e o que o autor define como filo maquínico:

1. o phylum maquínico: caracterizado nesse contexto como a linguagem binária computacional e a Infraestrutura informacional;

2. o phylum orgânico: caracterizado nesse contexto como a linguagem genômica do DNA;

Tal convergência suscitaria a formação de uma 'próxima natureza' dotada de materialidade informacional, ao mesmo tempo orgânica e artificial, capaz de se autoregular e ser, ao mesmo tempo, responsiva e dinâmica: "Na qual a informação-comocapital e o capital como informação se condensam e se descodificam em múltiplas espécies de vida artificial” (CHU, Karl, 2002, p.128).

\section{Metodologia, Meios De Produção e Tecnologias Envolvidas}

Karl Chu parte do estudo de um modelo informacional criado pelo matemático britânico Alan Turing, publicado inicialmente em um artigo de 1936. A UTM (Universal Turing

\footnotetext{
${ }^{20}$ Mônada: "Segundo Leibniz cada uma das substâncias simples e de numero infinito, de natureza psíquica (dotada de a percepção e a petição) , e que não tem qualquer relação umas com as outras, que e agregam harmoniosamente por préderteminação de uma divindade, constituindo as coisas de que a natureza se compõe(...)" (FERREIRA, 1999, p. 1357)
} 
Machine) mais conhecida como Máquina Universal, é um modelo computacional abstrato, que se restringe apenas aos aspectos lógicos de seu funcionamento (memória, estado da máquina e suas transições) e não à sua implementação física, que ocorreria apenas décadas mais tarde com a criação do primeiro computador. ${ }^{21}$

Karl Chu adota a Máquina Universal de Turing como o modelo conceitual capaz de fundamentar a hibridização entre códigos genéticos e códigos binários informacionais, caracterizando a formação de um novo sistema informacional híbrido:

"The birth of the Universal Turing Machine (UTM) marks the inauguration of the Hyperzoic Era (the artificial life of self-organizing systems) by redefining the projective content of the plane of immanence as information-theoretic in origin.(...) In its most significant form, the UTM is not merely another instrument in the history of technical inventions; it is a computational monad that redefines a new plane of immanence as the spectacle of a second order nature transposed onto the cultural universe of humanity that is founded upon the first order nature." (CHU, Karl. 2000, p.2) ${ }^{22}$.

Como um mecanismo generativo propõe-se que a UTM seja uma sequência linear de células que funcionam como o canal através do qual a informação é processada, incorporando o funcionamento maquínico da rede mundial de computadores em organismos informacionais.

Assim Karl Chu desloca a concepção de phylum maquínico (a rede mundial de computadores que compõe o espaço informacional) para phylum orgânico. Ambos integrariam essa 'próxima natureza' do espaço genético, receptor, portador e transmissor de informação.

\section{Reprodutibilidade tecnológica da obra}

Por se tratar de um dispositivo conceitual este item não se aplica à analise da obra. Visto que não dispõe de técnicas desenvolvidas para a sua execução e reprodução. Um

\footnotetext{
${ }^{21}$ Para mais informações sobre a Máquina de Turing consultar o vocábulo na Enciclopédia Filosófica da Universidade de Standford, disponível em: http://plato.stanford.edu/entries/church-turing/Acesso em: 29/09/2015.
}

${ }^{22}$ N. do A.: "O nascimento da Máquina Universal de Turing (UTM) marca a inauguração da era Hyperzóica (a vida artificial de sistemas de auto-organização) ao redefinir o conteudo projetual do plano de imanência como informação-teórica em sua origem. É o prenúncio de uma nova geração de espécies biomecânicas(...). Na sua forma mais significativa, a UTM não é apenas mais um instrumento na história das invenções técnicas; ela é uma mônada computacional que redefine um novo plano de imanência como o espetáculo de uma segunda natureza transposta para o universo cultural da humanidade, que está fundada sobre uma natureza de primeira ordem" (CHU, Karl. 2000, p.2, tradução nossa) 
sistema espacial que integre a informação digital e a protéica do DNA, presume-se que seja capaz de se reproduzir;

\section{Modos de extroversão}

Trata-se de um projeto conceitual realizado em plataforma digital, sendo que qualquer tipo de interação ocorre através da interface diretamente com o modelo em $3 d$.

\section{Imagens $^{23}$}

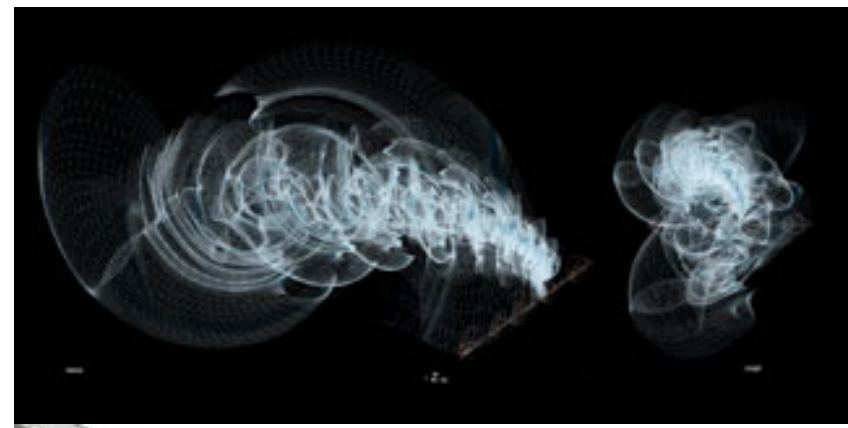

Fig. 14 - Plano de evolução do espaço genético a partir da Máquina de Turing;

\subsection{1.e - Sixth Sense | 2009| Pranav Mistry ${ }^{24}$}

Palavras-Chave: Realidade aumentada, Computação vestível, Interfaces gestuais;

\section{Descrição}

"Sexto sentido" é uma interface vestível que utiliza os gestos corporais para acionar e interagir com camadas de informação aplicadas ao espaço físico em torno do usuário

\footnotetext{
${ }^{23}$ Imagens disponíveis em: http://www.docam.ca/conservation/embryological-house/GL3ArchSig.html. Acesso em: 21/09/2015.

${ }^{24}$ Pranav Mistry é doutor em Interfaces Fluidas no MIT Media Lab, mestre em Artes e Ciências de Mídia do MIT e Design de Tecnologias da intêligencia de Bombaim. Pranav recebeu seu diploma de Bacharel em Engenharia da Computação do Instituto de Tecnologia de Nirma em Ahmedabad, Gujarat. Antes de ingressar no MIT, também trabalhou com a Microsoft como um pesquisador. No momento, ele é o Vice-Presidente Global de pesquisas da Samsung o chefe do Think Tank Team. Seus interesses de pesquisa incluem: interação tangível, Realidade Aumentada, Computaçao Ubiqua, Inteligência Colectiva e Robótica.
} 
(MISTRY et. al. 2009, p.2). Algumas peças formas o conjunto do Sexto Sentido: 1-uma câmera e um pequeno projetor acoplados a um pingente captam informações visuais e projetam imagens sobre superfícies, tais como paredes e objetos; da mesma forma sensores captam nossos gestos entendendo determinadas ações como comandos para executar as informações deste computador vestível.

\section{Objetivos}

A intensa miniaturização dos dispositivos de computação móvel permitem o acesso da informação "em qualquer lugar" o que nos torna hiper-conectados ao mundo digital e promove a ubiqüidade da esfera informacional. O principal objetivo do Sixth Sense (Sexto Sentido) é promover a ligação entre a nossa interação gestual e computadores vestíveis em interação com o mundo físico ao nosso redor e promover o acesso intuitivo entre corpo, espaço e informação. Associando comandos aos gestos das mãos e o conteúdo a qualquer superfície projetável. Este projeto de computação vestível, dilui a idéia de informações contidas em telas e dispositivos. Aqui a tela passa a ser qualquer superfície projetável.

Paralelamente, este projeto busca desenvolver a possibilidade de uma experiência interativa, que permita a participação simultânea de vários usuários interagindo com a mesma informação, pois é baseada em sensores interativos de toque que se acoplam aos dedos dos usuários e possibilitam interação intuitiva por gestos. Tais sistemas levaram a computação para as superfícies dos objetos, tais como mesas, paredes e qualquer outra superfície, não luminosa, em que se possa projetar a informação.

Embora seja impraticável modificar todos os objetos físicos e superfícies, para conterem telas, o que este projeto faz é levar a "tela", ou melhor, a projeção de imagens para qualquer superfície e transformá-las em superfícies interativas, sejam elas seres vivos, edifícios ou objetos. Dessa forma, quando a informação digital é projetada sobre objetos físicos, instintivamente, interagimos com ela por padrões semelhantes ao que usamos ao interagir com objetos físicos: através de gestos com as mãos, que são lidos pelos anéis sensores, interpretados via código e transformados em interação, com a imagem projetada.

\section{Metodologia, Tecnologias Envolvidas, Reprodutibilidade tecnológica da obra}


O protótipo sexto sentido é composto de um projetor de bolso, um espelho e uma câmara. Os componentes de hardware são acoplados em um pingente como o dispositivo wearable móvel. Tanto o projetor como a câmera estão conectados ao dispositivo de computação móvel no bolso do usuário. 0 projetor incide a informação visual em superfícies próximas ao seu corpo, que serão usadas como interfaces interativas; Enquanto a câmara reconhece e acompanha gestos com as mãos e objetos físicos com técnicas baseadas em computação de Visão do usuário, o programa de software processa os dados de fluxo de vídeo capturadas pela câmera e rastreia os locais dos marcadores coloridos (fiduciais acompanhamento visual) na ponta dos dedos usando técnicas de computador de visão simples. Os movimentos e arranjos dessas fiduciais são interpretados em gestos que atuam como comandos de interação para as interfaces de aplicativos projetados.

\section{Modos de extroversão}

O número máximo de dedos monitorados só é limitado pelo número de fiduciais únicas, assim SixthSense também suporta multi-usuários e multi-toques de interação. Dessa forma se expande a relação predominante de um usuário para cada dispositivo, pois conforme o dito uma mesma superfície interativa pode ser acionada por vários usuários ao mesmo tempo.

\section{Imagens ${ }^{25}$}

\footnotetext{
${ }^{25}$ Imagens disponíveis em: http://www.pranavmistry.com/projects/sixthsense/\#PICTURES. Acesso em: 5/10/2015
} 

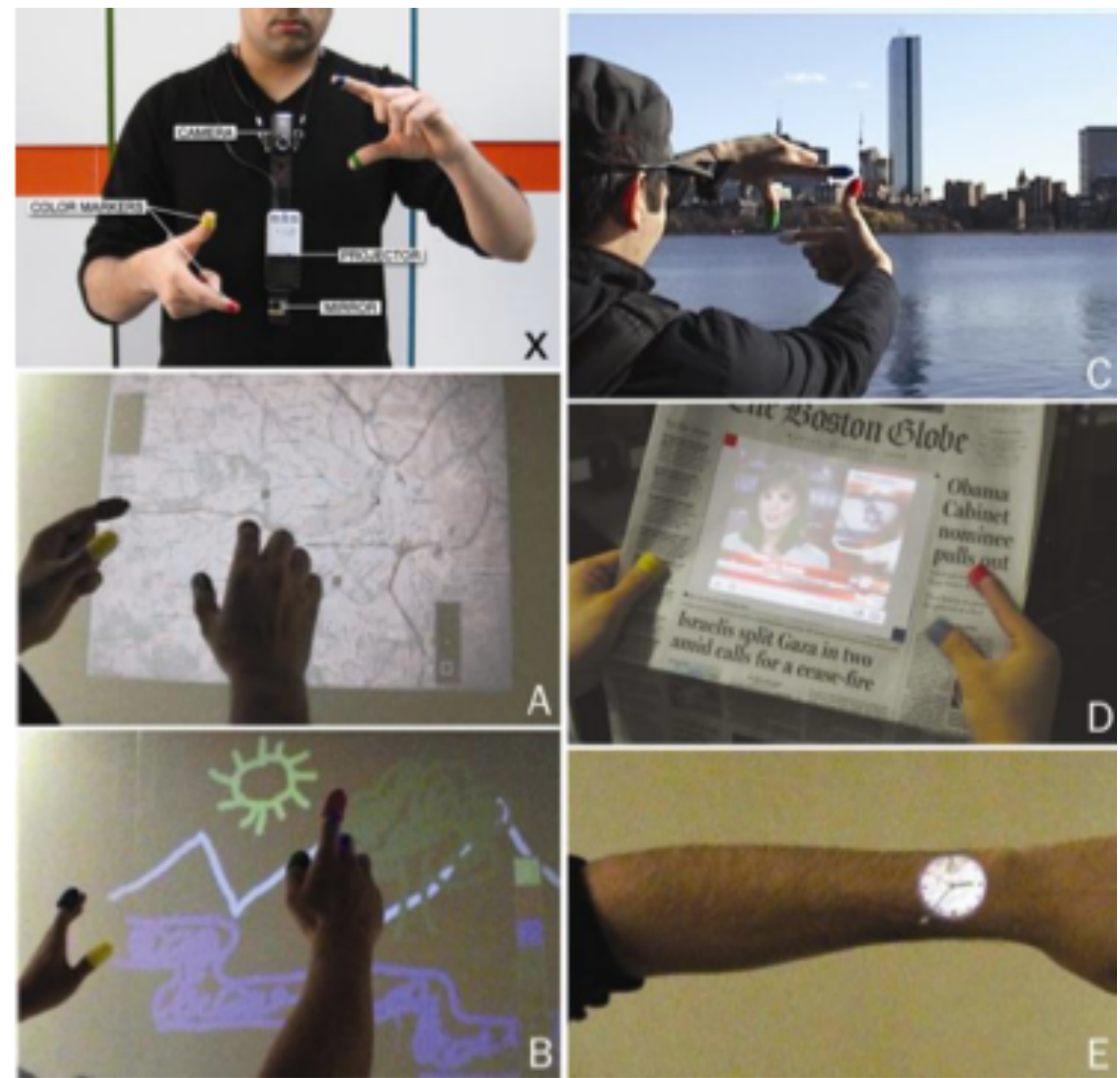

Fig. 15 - método de interação entre o computador vestível e o ambiente

\subsubsection{Relações Externas das Obras}

\section{2.a - Nascimento da arquitetura virtual}

No fim do século XIX, o impacto da revolução industrial foi amplamente sentido na arquitetura e no urbanismo. Os novos modos de produção e de trabalho associados as inovações técnicas dos modos de produção (energia elétrica, telefone, automóvel), rapidamente transformaram os modos de viver nos populosos centros urbanos. Sob a perspectiva das condições materiais que ocasionaram a aceleração temporal da vida nos centros urbanos, a mobilidade é um fator chave de entendimento desta aceleração: a mobilidade física das redes de transporte, a mobilidade comunicacional da invenções como o telégrafo, telefone, televisão e radio, a mobilidade dos fluxos financeiros e da produção fabril proporcionada pelas linhas de montagem. 
Para André Lemos a cidade constitui-se, historicamente, como lugar de mobilidade e fixação, o espaço onde as práticas sociais se reconfiguram com a emergência das novas tecnologias de comunicação e das redes telemáticas.

No final do século $X X$, com a reconfiguração e formação dos grandes centros econômicos, houve novamente um deslocamento em relação aos meios de produção de toda cultura material, juntamente com o desenvolvimento de novos meios de telecomunicação. O Neoliberalismo ampliou mundialmente suas esferas de produção, com a formação dos blocos econômicos e, associada a essa formação, um novo meio técnico-científico-informacional (SANTOS, 2000) capaz de interligar estes centros pósindustriais à rede mundial de computadores. Milton Santos descreve a construção ideológica da globalidade: "Fala-se em aldeia global para fazer crer que a difusão instantânea de notícias realmente informa as pessoas. A partir desse mito e do encurtamento das distâncias - para aqueles que realmente podem viajar - também se difunde a noção de tempo e espaço contraídos." ( Santos, 2000, p.18-19). Milton Santos compreende a sucessão de períodos de "modernização" interligados diretamente à sucessões de sistemas técnicos. Para ele é com o desenvolvimento e a incorporação dos sistemas tecnológicos informacionais nas formas de produção, que ele identifica a instantaneidade dos momentos e dos lugares, a universalidade e unicidade das técnicas. Para Castells, diferente de qualquer outra revolução, o cerne da transformação que estamos vivendo na revolução atual refere-se às tecnologias da informação, processamento e comunicação.

\subsection{2.a - 0 Espaço na arquitetura virtual}

É no final do século $X X$, com as questões que se delineiam em torno a este novo meio informacional que a arquitetura passa a incorporar a dimensão virtual, em seu modo específico de pensar e produzir o espaço.

Para Peter Eisenman a incorporação do meio virtual como um novo espaço para a arquitetura e para o urbanismo, não se dá sem uma certa resistência, pois sua incorporação implica em uma série de consequências para o papel da arquitetura como representação visual dos valores da sociedade, especialmente no que se refere às idéias sobre realidade, o original e sua percepção, centrada predominantemente no sentido da 
visão: "o principal termo discursivo da arquitetura é o sujeito humano dotado de visão monocular e antropocêntrica”.(EISENMAN apud. NESBIT, 2008, p.599).

Com se sabe a visão racional, principalmente a visão calcada no campo perspéctico, foi historicamente determinante do desenho arquitetônico como uma forma de expressão de uma visão de realidade racional e inspirada no mecanicismo. Para Eisenman a arquitetura jamais conseguirá ultrapassar a visão de mundo renascentista se não promover uma profunda crítica da representação e reverter as categorias estéticas que moldam nossa noção de espaço, e é justamente esse conceito tradicional de visão que o meio informacional põe em cheque. (NESBIT, 2008).

Não há, no entanto um consenso teórico sobre o conceito de lugar, especialmente sobre a distinção conceitual entre lugar e espaço. Convencionalmente, como disse Peter Eisenman, na modernidade a formulação de espaço trata de uma noção geométrica de representação formal. Alguns autores defendem que a intensificação da paleta visual na modernidade ocidental tenha iniciado em 1400 d.c. com a imprensa de Guttenberg e a intensificação da mídia escrita, enquanto outros se referem ao campo perspéctico renascentista que adotou a geometria euclidiana como meio projeção objetiva do espaço adotando o more geométrico cartesiano.

$\mathrm{Na}$ interpretação predominante da geografia humanista sobre a relação entre espaço e o lugar, o primeiro é visto como uma categoria objetiva de demarcação física e geológica e o segundo como um construto cultural aliado a percepção estética e fenomenológica (SIMMEL, 2011). Já para Michel de Certeau (1984) o lugar é uma forma de "localização" um lugar para ser experimentado e dessa forma o lugar, é o espaço investido de relações culturais. Uma vez que nossa percepção do mundo é predominantemente visual o mundo é percebido de forma tridimensional e sentido, na formulação fenomenológica do termo, sinestesicamente. Portanto a percepção humana não é limitada apenas pelo espaço tridimensional, mas por relações dialéticas de significação que se estabelecem a partir do lugar.

Como agentes da cultura ocidental concebemos o espaço em seu sentido absoluto, conforme os pressupostos teóricos com os quais operamos a maior parte do tempo (por exemplo a Física Newtoniana e a Geometria Euclideana). No entanto, sentimos e experimentamos o espaço, a partir das relações que os elementos dentro de nosso campo de visão estabelecem entre si e com nosso corpo. Michel de Certau articula a noção de espacialidade a partir do cotidiano e diferencia a conceituação do espaço 
(espaço absoluto concebido pelo pensamento) das experiências espaciais (concebido pelos sentidos). Para De Certeau a experimentação do espaço, antes mesmo de sua conceituação, orienta, circunstância e temporaliza a noção de espaço.

Um índice desta constatação de Eisenman é a distinção que se cria erroneamente entre real e virtual, como se apenas os índices circunscritos à materialidade e portanto visibilidade da forma espacial denotassem as categorias do real. Ora, em um meio, em que a maior parte da comunicação é feita via a transmissão de sinais eletromagnéticos de rádio, TV ou mesmo Wi-fi, não se pode afirmar que este espaço comunicacional criado pelas telecomunicações seja de fato imaterial ou então "oposição" do "mundo real".

De fato, o ciberespaço não é fundado sob as mesmas regras espaciais que regem a arquitetura desde a renascença, e a incorporação do ciberespaço no discurso arquitetônico implica, como vimos no mapeamento de obras, a revisão metódica dos pressupostos mais arraigados da arquitetura, de Vitrúvio à Virilio. A incorporação do ciberespaço, portanto, se torna um meio central na discussão de novas categorias conceituais do espaço e do tempo para a epistemologia da arquitetura.

\subsection{2.b Análise relacional das obras e transição para os espaços cíbridos}

A partir do mapeamento de obras feito na primeira parte deste capítulo, pode-se traçar como esta primeira geração de arquitetos reformulou suas metodologias de projeto para estabelecer os parâmetros de investigação e experimentação do espaços cíbridos:

1- primeiro pressuposto: a revisão da linguagem cartesiana na representação de projeto e o desenvolvimento das linguagem paramétrica e generativa;

2- segundo pressuposto: a substituição da representação pela experiência do espaço e como consequência, o desenvolvimento de um espaço sensível e interativo, 
que prioriza o corpo como matriz sensória na experimentação fenomenológica desse espaço;

3- terceiro pressuposto: a busca de uma nova linguagem e meios materiais para uma arquitetura móvel e sensível;

$\mathrm{Na}$ busca de conceituar esse campo de hibridização entre a arquitetura e o meio informacional, Marcos Novak elabora uma série de terminologias que transitam em torno do intercruzamento do espaço físico e informacional: Arquitetura Líquida, Transarquitetura e Transmodernidade, entre outros. Novak compreende o espaço em seu sentido mais genérico e até mesmo impreciso em relação a formação dessas novas terminologias. A singularidade desses conceitos é a proposição de que o ciberespaço se constitui como um espaço arquitetônico autônomo, dotado de singularidades que o colocariam na condição de um novo espaço arquitetônico. Portanto a Transarquitetura trata de uma terceira condição ${ }^{26}$, uma qualidade espacial que emerge da sucessiva diluição entre a oposição de definições binárias como hardwares e softwares, real e virtual, físico e digital, etc.

Como os demais arquitetos de sua geração, Lars Spuybroek/NOX recusa o determinismo funcional e formal. Sua proposição de um edifício como paisagem resulta de seu interesse pelas possibilidades que a forma dinâmica e animada oferecem. Quando Lars Spuybroek projeta espaços que rompem com a noção de referente espacial, mesclando e confundindo pisos, paredes e coberturas, ele está priorizando a imersão do corpo na obra a partir da perda referenciais do espaço objetivo. No caso do Pavilhão FreshH20 Expo ou Pavilhão da Água Doce, busca-se o aprimoramento da experiência de imersão dos usuários acoplando as mídias digitais de vídeos, imagens e sons, além da iluminação que se transforma a partir da presença captada por biosensores. Lars Spuybroek desenvolve a noção de ambiência interativa na qual privilegia a experimentação corporal e sinestésica do espaço da obra. Ali cada ambiente pode ser modificado a partir de sensores de presença e painéis de comando que modificam a atmosfera do lugar.

A Arquitetura Maquínica de Lars Spuybroek estuda o desenvolvimento metodológico destes espaços sensíveis. Cada máquina introduz no processo de produção um corte conceitual nas linguagens de projeto. Dessa forma a primeira máquina (drilling) é a

\footnotetext{
${ }^{26}$ Este "terceiro espaço" se aproxima conceitualmente do que Peter Anders definiu como espaços Cíbrido: termo que designa o ciberespaço híbrido.
} 
máquina que insere uma primeira abstração no sistema: olho-mão-tela. A segunda máquina (abstracting) opera a abstração da modelagem em três dimensões. A terceira máquina (surfacing) planifica o modelo para a superfície impressa. A quarta máquina (structuring) dá estrutura ao modelo, não apenas superficialmente, mas dá a densidade da abra a partir da aplicação de materiais e renderização. Por fim, a quinta máquina (modeling) agrega no processo as diferentes dimensões anteriormente exploradas finalizando o projeto. É importante salientar que o modelagem da arquitetura virtual adquire o estatuto da obra nesse caso.

De maneira inversa, Greg Lynn adota uma estratégia de projeto que busca incorporar o movimento interativo do ciberespaço em uma casa embriológica. Um habitat capaz de formar um organismo responsivo que atue em simbiose com os usuários. Seu estudo envolve a complexidade geométrica crescente de materiais que interagem com o usuário e se transformam. Porém esta tentativa de aplicar a interatividade computacional aos painéis de aço, madeira ou metal de seus protótipos, não alcança inteiramente os pressupostos de uma arquitetura interativa, pois a limitação material dos painéis envolvem limites máximos e mínimos, que impedem a autonomia dinâmica do espaço. E ainda que Greg Lynn adote a imagem de um embrião para se referir a sua obra como um organismo, capaz de se desenvolver, crescer e se reproduzir, sua obra ainda carece de materiais que a façam cumprir esta proposta. Sua obra alcança a máxima potência como projeto conceitual e virtual, ao lançar as bases para um meio material que agregue e transmita informação a partir da interação dinâmica com seus usuários. A arquitetura experimental de Greg Lynn rompe com a representação sendo ao mesmo tempo modelo e objeto e adquire interatividade e proporções dinâmicas, se assemelhando a um organismo artificial que quebrando os pressupostos da arquitetura como estabilidade e duração no espaço. Incorpora o tempo como condição fundamental de transitoriedade dinâmica.

Assim como Greg Lynn, Karl Chu atua na elaboração do conceito de uma arquitetura genética. Para isso ele estuda o modelo da Máquina Universal de Turing, um modelo matemático que segundo ele poderia entrecruzar informação genética e digital, capaz de atuar na formação materiais orgânicos e artificiais, que se reproduzissem, agregassem e transmitissem informação digital, como uma fita de DNA. Correndo o risco de adotar uma perspectiva positivista dos modelos científicos universais que buscavam uma certa totalização do conhecimento, característicos do início do período 
moderno, Karl Chu propõe que a Máquina Universal de Turing, comporia o universo epistemológico capaz de promover a fusão entre informação e matéria:

“(...) Uma alquimia mecânica de subjetivação que envolve tanto o sujeito e o objeto da arquitetura neste meio instrumental através da geração de uma superfície universal sobre a qual uma realidade mutante pode se esfoliar em um mundo possível." (CHU, Karl. 2000, p.2)

Por fim elegeu-se o design interrogativo de Pranav Mistry para abordar a transição deste espaço computacional da máquina para o corpo. Mistry, desenvolve um computador vestível, capaz de interagir com qualquer superfície física, transformandoas em superfícies significantes e com isso aponta para a dissolução do modelo maquínico do computador e sua integração nos espaços dos objetos, das edificações, das cidades a partir de outra matriz: os corpos em interação direta com o espaço. Tratase de um deslocamento no sentido de conceber as relações entre corpo e máquina, que ultrapassam os limites da tela do computados como superfície sígnica. Qualquer superfície projetável pode se tornar uma computador sem ser dotada de circuitos informacionais. Aqui é o corpo que transporta os dispositivos necessário para a projeção de uma interface interativa e o espaço que recebe, como superfície esta informação. Esse projeto ainda rompe com a relação individual que se estabelece, tanto com o computador como com os dispositivos móveis, liberando a projeçao para ser manipulada por até 5 usuários, através dos gestos.

Estes cinco projetos abordam maneiras diferentes de conceber a integração entre o ciberespaço e a arquitetura, e embora as metodologias e a epistemologia do espaço de cada obra varie, há entre elas o mesmo objetivo: o de estudar e inserir no imaginário da arquitetura a ideia do cibridismo (ANDERS, 1997), uma nova condição espacial, interligada em rede e dotada de informação, que possa ser produzida, reproduzida, armazenada e transmitida pelo espaço arquitetônico.

Tuters e Varnelis (2006) quando se referem às mídias locativas, dizem que logo a rede mundial de computadores será composta da interligação de objetos em rede transmitindo dados entre si, em número maior do que humanos conectados em rede. Esta previsão sobre a internet das coisas, tem implicações para o espaço informacional que ultrapassam em muito a especialização de cada disciplina, não é apenas a arquitetura ou o design que terão que lidar com as questões desse novo meio que permeia a rede de computadores, os edifícios, os espaços urbanos e até os corpos. 
Segundo Giselle Beiguelman (2013) não se trata mais de discutir um meio virtual alheio a espacialidade física dos objetos a internet 1.0 deu lugar a um espaço híbrido, pós-virtual:

"Não há dúvida. A era do virtual ficou na primeira década do século. O real engole tudo e nos põe no centro de redes interconectadas acessíveis, literalmente, na palma da mão. Vivemos no mundo do pós-virtual e isso não significa apostar numa volta ao mundo analógico. Ao contrário. Significa assumir que as redes se tornaram tão presentes no cotidiano e que o processo de digitalização da cultura é tão abrangente, que se tornou anacrônico pensar na dicotomia real-virtual. 0 mundo da Internet das Coisas já se anuncia no presente, prevendo que todos os objetos do cotidiano estarão conectados às redes e entre si." (BEIGUELMAN, 2013, p.148).

Embora este mapeamento de arquitetura se dedique a discutir as possíveis formas de pensar esta hibridização: entre arquitetura e meio informacional, a Internet das Coisas, já acontece cotidianamente, por meio de realidade aumentada, Qr-codes, etiquetas de RFid e todos os bancos de dados interligados aos chips mais improváveis: do celular ao cartão de crédito.

\section{2 - Cartografando das obras de arte}

Se a princípio, ao estudarmos as obras conceituais e práticas da arquitetura, nos deparamos com concepções epistemológicas de um novo lugar, um espaço de relações que além de promover revisão das linguagens de representação de projeto, buscam a conceber uma espacialidade responsiva e dinâmica, como resultado da hibridização entre meio informacional, novas mídias, arquitetura e corpo. Por outro lado é no campo da arte feita com mídias móveis, que se percebe um outro campo de significações que surgem desta hibridização. O princípio norteador de escolha deste mapeamento, foi a gama de possibilidades estéticas mediadas pelos aparelhos móveis de comunicação que conectam o caminhar em rede e que, de diferentes formas, ampliam os modos de sentir, 
perceber, representar e produzir relações em contexto com o espaço percorrido.

A arte feita com mídias locativas busca um outro espaço, um lugar específico ${ }^{27}$ e relacional entre a apropriação do espaço urbano e das mídias móveis, rumo a uma ruptura significante em meio aos modos de produzir e se apropriar desse espaço repleto de territorializações informacionais: sinais wi-fi, sistemas de rastreamento como o Rfid, câmeras de vigilância, demarcações sonoras do espaço público, etc.

O presente capítulo pretende apontar a transição ocorrida no caminhar como prática estética a partir da primeira década do séc.XXI com a popularização das tecnologias móveis associadas aos dispositivos de geolocalização apontam para o caminhar mediado e permitem a difusão do fazer artístico em rede, trazendo à tona a questão da mobilidade e da locatividade informacionais.

Ainda que estas questões tenham surgido a partir da disseminação da mídias móveis, a grande maioria das obras mapeadas desenvolve aplicativos e dispositivos específicos, seja como forma de driblar e contestar as políticas de propriedade intelectual, de vigilância e controle, de armazenamento de dados pessoais ou mesmo da monopólio e homogeneidade da produção dos meio informacionais ou então como forma de estabelecer relações de singularidade, no contexto dos lugares que atravessam, que é o caso, como veremos, dos Megafone.Net e do Tatical Sound Garden.

Os territórios informacionais se inserem em um regime de complexidade crescente, produzindo e englobando aspectos simbólicos, econômicos, políticos, aliados à infraestrutura informacional dos bancos de dados, dispositivos e sensores sem fio, portáteis e eletrônicos, ativados a partir da localização e da movimentação de seus usuários, compondo junto aos lugares, uma nova territorialidade: o território informacional (LEMOS, 2009).

É nesse sentido, o da produção de lugares, que as mídias locativas e táticas se posicionam criticamente deslocando e potencializando o contexto que tem início na década de 60 com as rupturas nos modos de fazer, circular e dar visibilidade ao regime das artes, gerando novas formas de investigar as metrópoles através da mobilidade e seus fluxos.

\subsection{1 - Relações Internas das Obras}




\subsection{1.a - Can You See Me Now? | 2003-2006 | Blast Theory ${ }^{28}$}

Palavras-Chave: Games Locativos, realidade mista, pervasividade, intercomunicação ativa;

\section{Descrição}

Trata-se de um jogo locativo experimental de realidade mista ${ }^{29}$ produzido com o apoio da Engineering and Physical Sciences Research Council (EPSRC) através da The Equator Interdisciplinary Research Collaboration ${ }^{30}$, em Londres, juntamente com 0 coletivo de artistas do Blast Theory ${ }^{31}$, que reuniu uma equipe interdisciplinar de pesquisadores de ciências da computação, ciências sociais, psicologia, arte, design, além do coletivo Blast Theory, formado por 4 artistas radicados em Londres, que realizam, desde 1991, performances envolvendo tecnologias computacionais para teatros, galerias e espaços públicos.

CYSMN? (Can You See Me Now?) é um game baseado em mídias locativas realizado com aproximadamente 20 jogadores que são perseguidos por membros do Blast Theory, os corredores (runners). 0 objetivo do jogo é evitar que os jogadores sejam vistos pelos corredores. A ação se dá em espaços públicos pré-definidos e simultaneamente em um ambiente virtual conectado em tempo real com os jogadores.

A participação dos jogadores começa com um login em uma homepage específica, onde se pode visualizar o mapa esquemático da região, contendo o posicionamento dos jogadores e corredores. A comunicação entre os participantes acontece via mensagens de texto e de áudio, via rádio (walkie-talkies), entre 3 corredores (perseguidores). As mensagens de texto e áudio podem ser acessadas pelos oponentes via internet, a fim de criar táticas de fuga e perseguição.

O jogo foi realizado em várias cidades, inclusive em Belo Horizonte no Brasil. A participação de muitos jogadores proporcionou uma valiosa oportunidade de aprender sobre as formas de interação feitas com realidade mista.

\section{Objetivos}

Segundo o coletivo Blast Theory, o objetivo ao desenvolver este game locativo é investigar a natureza social dos jogos de realidade mista. Explorar suas diferentes

\footnotetext{
${ }^{28}$ Blast Theory é composto por: Matt Adams, Ju Row Farr e Nick Tandavanitj. 29 Ver Glossário; 30 Disponível em: https://www.epsrc.ac.uk . Acesso em: 07/06/2015. 31 Disponível em: http://www.blasttheory.co.uk. Acesso em: 07/06/2015.
} 
perspectivas e capacidades de acesso e manipulação de diferentes tipos de informação entre jogadores on-line e na rua.

\section{Metodologia}

O grupo aponta duas questões principais que são desenvolvidas durante os jogos: 1 . Que relações possíveis podem se estabelecer entre os jogadores on-line em interação com aqueles que jogam nas ruas? 2. Como se dá o desenvolvimento das bases tecnológicas para esse tipo de comunicação em realidade mista ou como potencializar ou confundir esse desenvolvimento?

O primeiro passo para o aprimoramento do jogo foi a etnologia. Durante a fase de desenvolvimento do jogo, o grupo solicitou o feed-back dos participantes, pesquisadores e corredores, obtendo material em grande quantidade (de vídeo, áudio, texto e conversas) para suas observações etnográficas:

"Nós fizemos observações etnográficas (utilizando vídeos e anotações de campo) das atividades de diferentes participantes, incluindo corredores, jogadores e equipe de produção por trás da cena. A etnografia é um método natural de observação que busca fornecer ricas descrições da organização social do trabalho em contexto. É um dos métodos mais antigos do arsenal investigação social e tem sido considerado de grande utilidade para os designers de tecnologias interativas." (ADAMS et. al., 2003, p.10, tradução nossa)

O grupo Blast Theory aponta dois métodos de aplicação do jogo: a orquestração e a jogabilidade. A orquestração (ou gestão do jogo) envolve a manutenção constante das interfaces para garantir que nenhum problema técnico interfira na fruição do jogo, e a Jogabilidade envolve, tanto as estratégias desenvolvidas pelos corredores e jogadores, quanto a exploração do local para definir melhores rotas de fuga. Além da importância do processo de comunicação para o reconhecimento local entre os jogadores.

\section{Meios De Produção E Tecnologias Envolvidas}

O jogo é composto por 4 módulos de comunicação:

- 0 servidor: composto de antena transmissora de sinal wi-fi ${ }^{32}$ e um dispositivo GPS; (Fig.1). além da elaboração de uma torre autônoma de transmissão desses sinais. A potência dessa torre determinou a extensão espacial do jogo.

\footnotetext{
32 modelo 802.11b. (Ver glossário de termos;)
} 
- A Sala de Controle (Fig.2): onde se monitora a orquestração remota do jogo. A sala reúne tanto dispositivos que controlam a qualidade dos sinais emitidos para cada um dos jogadores, como computadores que monitoram a interface do jogo (Fig.3).

- O sistema posicionamento e mensagens: ao entrar no jogo, cada jogador recebe um kit de mensgens o iPAQ, contendo um Palm e um GPS conectados a um servidor de internet específico que permite a interação de no máximo 20 jogadores. Ao se conectar ao servidor os jogadores já podem se comunicar com outros jogadores através do IPaq e seu posicionamento passa a ser constantemente atualizado na interface do jogo (Fig.4).

- O sub-sistema de áudio: os corredores do jogo (ou perseguidores) se comunicam usando walkie-talkies ${ }^{33}$ (Fig.5). A comunicação entre eles é reproduzida para todos os jogadores através de um walkie-talkie adicional, que fica na sala de controle, conectado a um computador local que digitaliza o som, utilizando o programa Sorenson Broadcasterg ${ }^{34}$ e o re-transmite aos jogadores via streaming ${ }^{35}$ com o aplicativo Darwing ${ }^{36}$ (Fig.6).

\section{Reprodutibilidade tecnológica da obra}

Embora o período de desenvolvimento do jogo tenha acontecido entre 2001 e 2002, e portanto no início da difusão massiva dos celulares com função de áudio e vídeo, há uma certa antecipação das funções que os celulares viriam a centralizar em um único aparelho: geolocalização, texto, áudio, transmissão via streaming. 0 desenvolvimento desta obra antecipa os agenciamentos que se produziriam posteriormente, de forma massiva no espaço público, a partir da difusão deste tipo de mediação comunicativa, tais como o rastreamento e mapeamento de trajetórias em tempo real.

É Possível perceber ainda a dificuldade inicial de se representar o espaço físico das cidades em um meio virtual, mesmo que sob uma vista de topo e portanto esquematizada, objetivada. Se hoje dispomos de acesso fácil à mapas de diversos meios urbanos, ao contrário os artistas do Blast Theory desenhavam esquematicamente a representação de topo dos locais onde se desenvolveria o jogo para que se pudesse

\footnotetext{
${ }^{33}$ Ver glossário;

${ }^{34}$ Para mais informações sobre o programa acesse: http://www.sorenson.com. Acesso em: 12/02/2016.Ver glossário;

${ }^{35}$ Streaming: fluxo de mídia. Sistema de transmissão de vídeos imagens e sons em tempo real, possibilitando encontros de pessoas online. Para mais informações acesse: https://pt.wikipedia.org/wiki/Streaming. Acesso em: 12/02/2016.

${ }^{36}$ Para mais informações para 0 aplicativo acesse: http://www.darwin.com.br, Acesso em: 12/02/2016.
} 
determinar seu posicionamento. 0 que delimitou a área de jogabilidade foi a potência da torre de transmissão de sinal e o que delimitou a quantidade de jogadores foi a capacidade de logins no servidor do jogo.

\section{Modos de extroversão}

Jogo de realidade mista colaborativo, feito para participantes que interagem em um espaço público pré-definido;

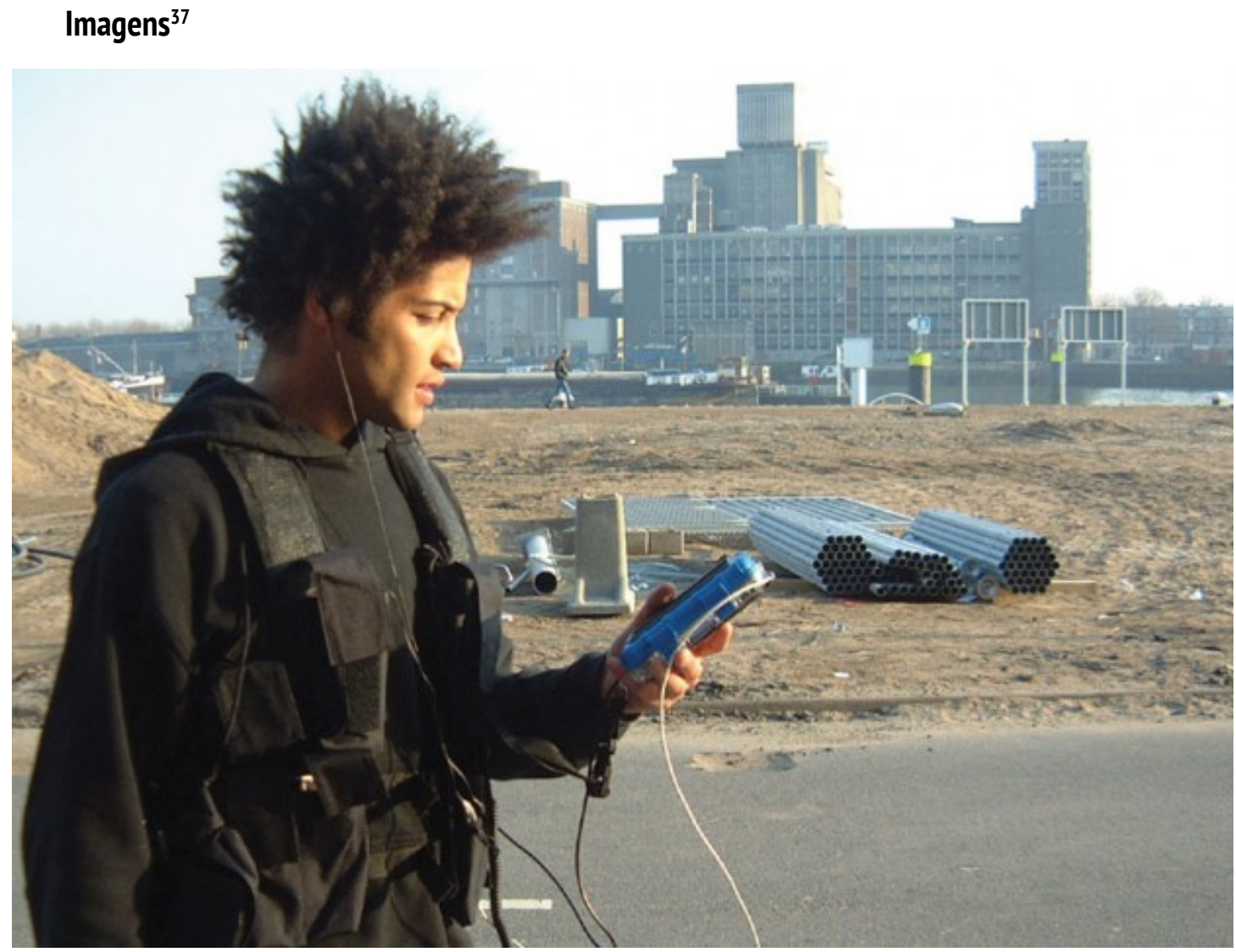

Fig. 16 - Jogador em ação

\footnotetext{
${ }^{37}$ Imagens disponíveis em: http://www.blasttheory.co.uk/projects/can-you-see-me-now. Acessado em: 12/02/2016;
} 

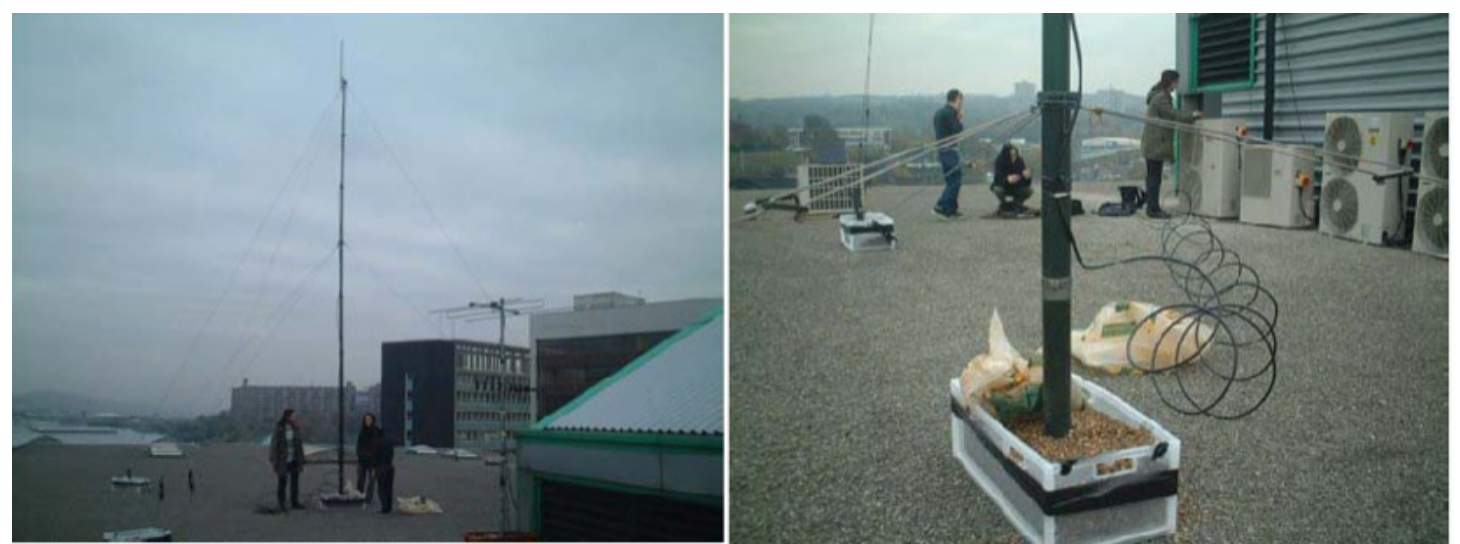

Fig. 17 - torre de transmissão

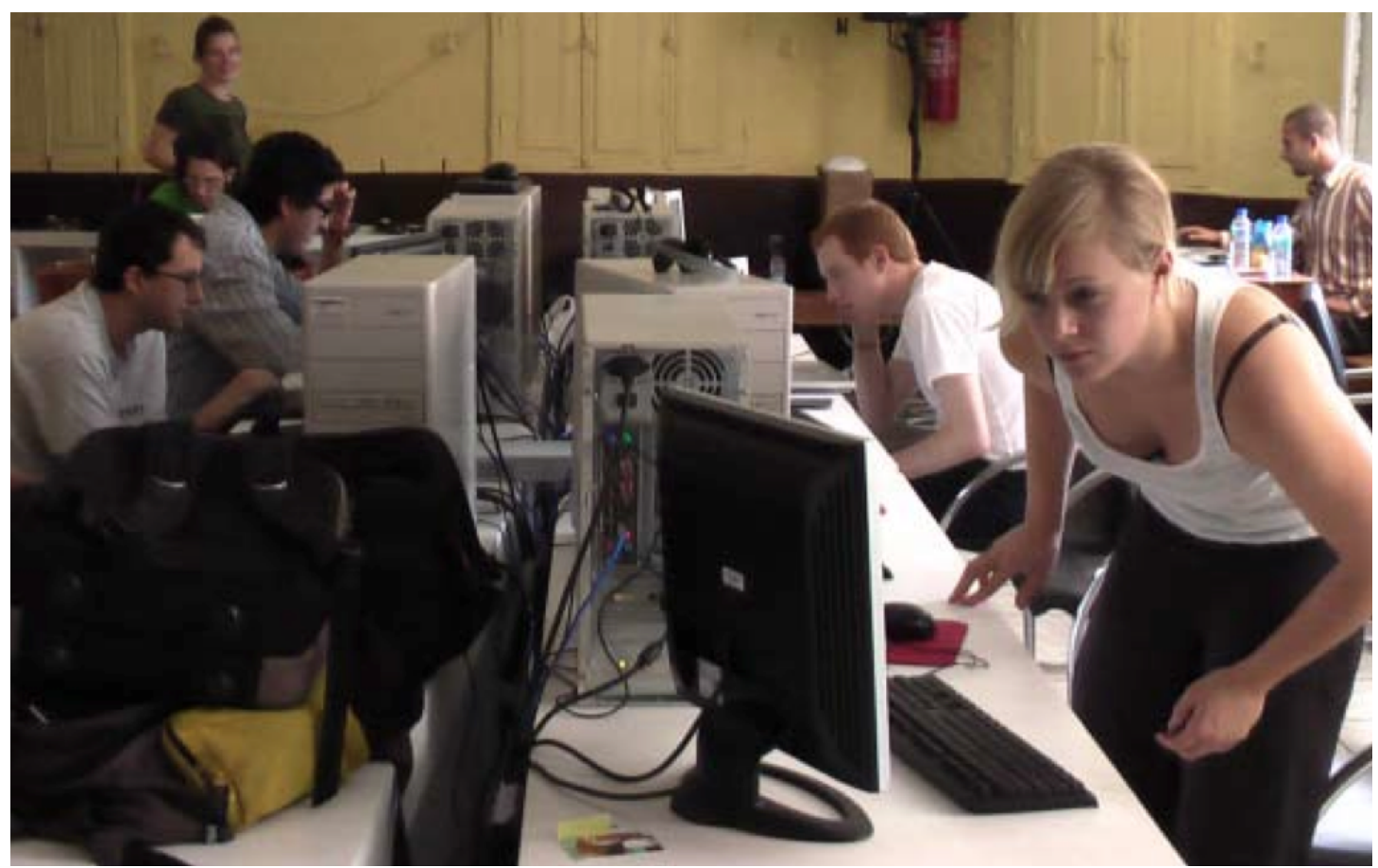

Figura 18 - Sala de Controle, edição Vivo Arte.Mov no bairro de Santa Teresa - Belo horizonte - MG (2006).

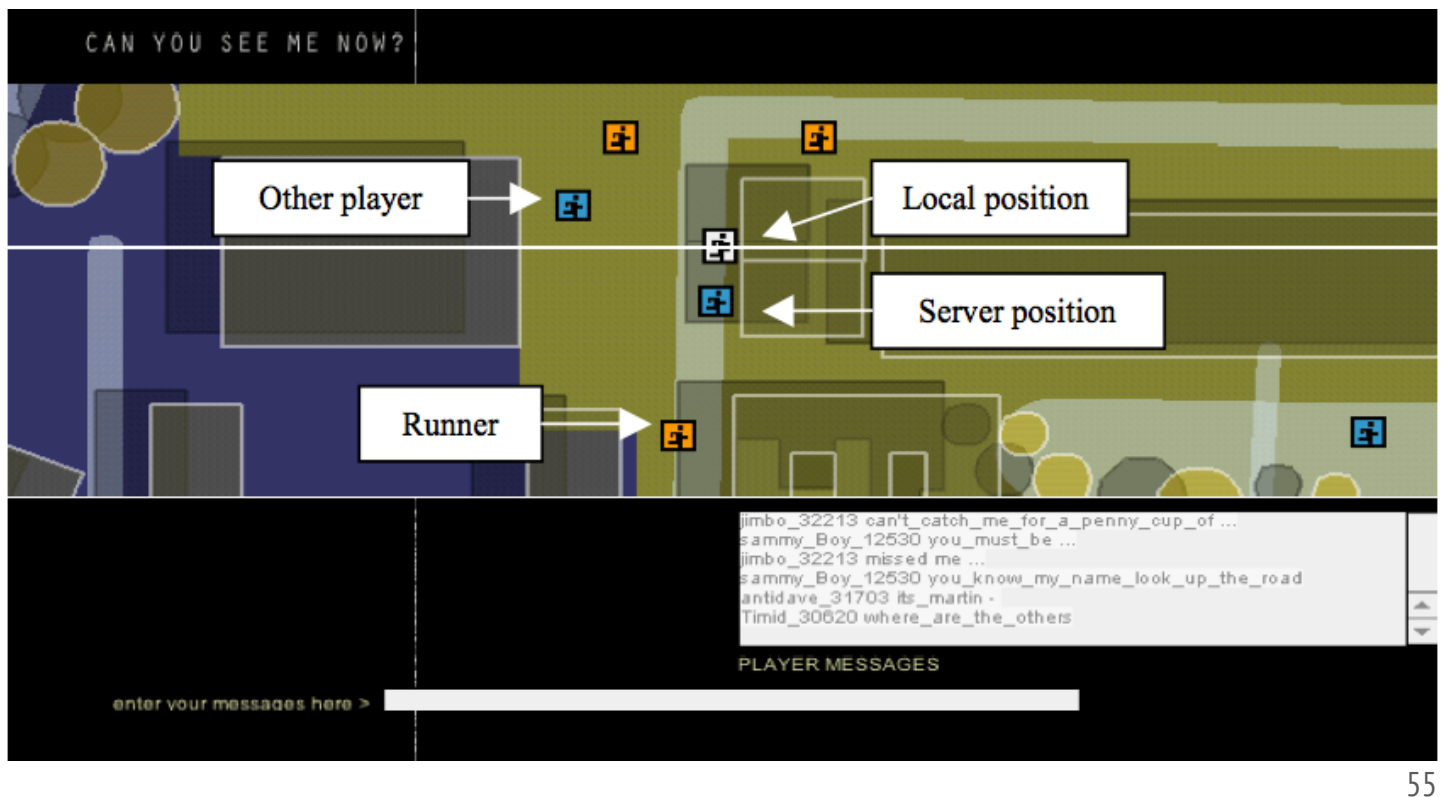


Figura 19 - Interface da homepage do jogo contendo o posicionamento dos jogadores em um mapa esquemático da cidade;

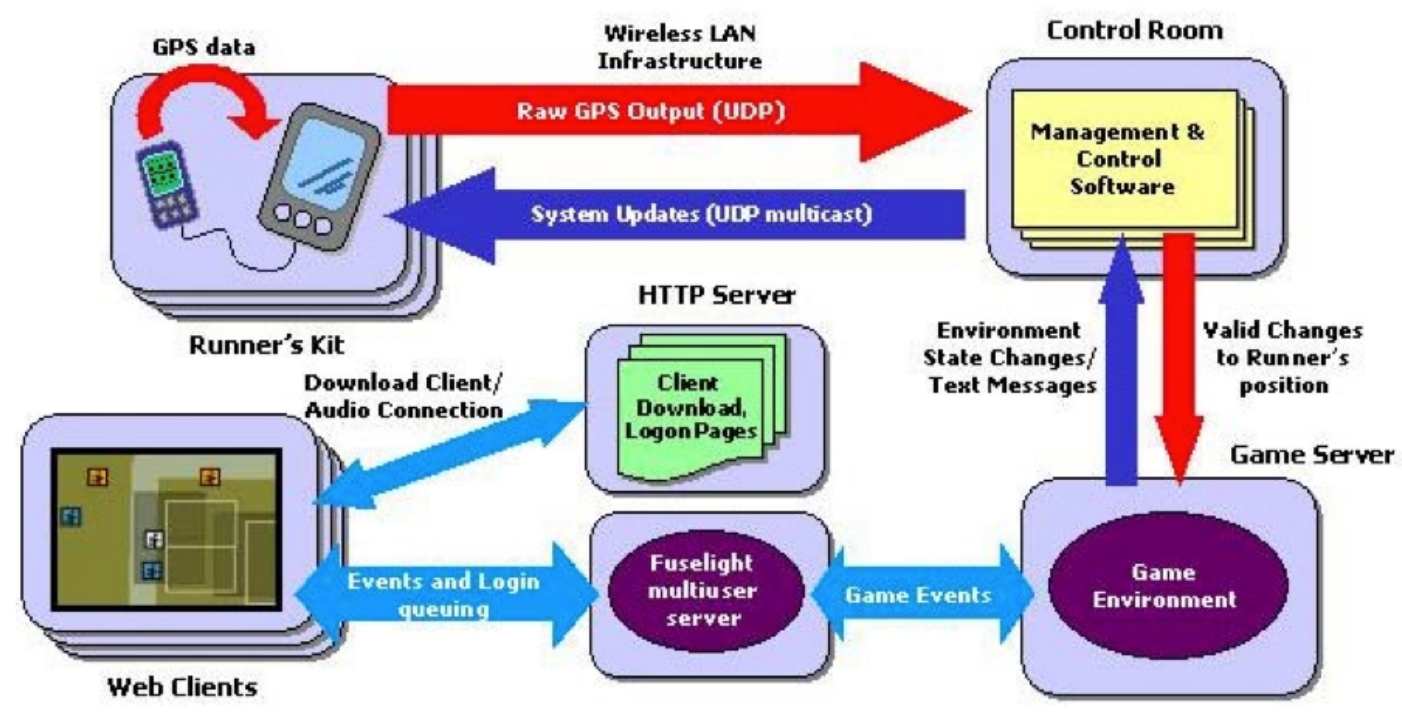

Figura 20 - Sub-sistema de mensagens de texto e posicionamento dos jogadores;

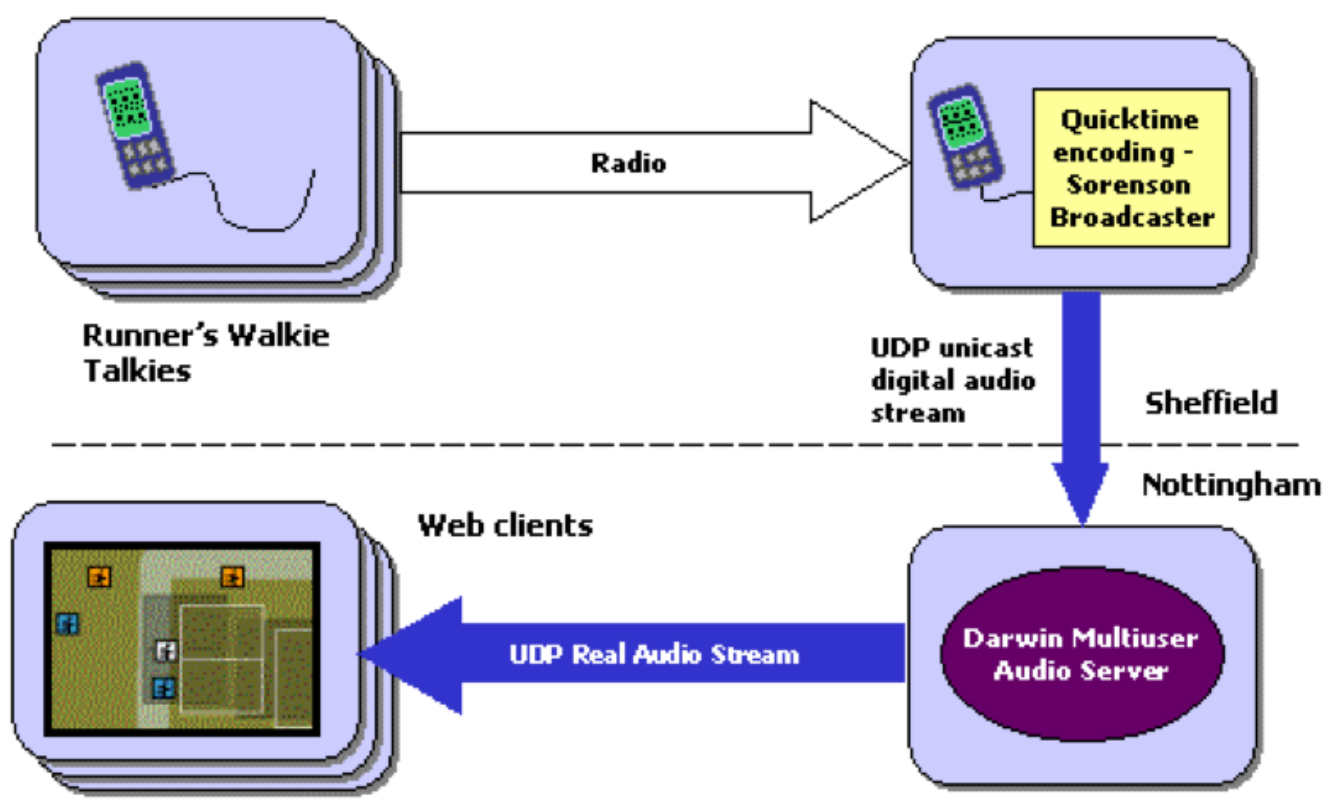

Figura 21 - Esquema do Sub-sistema de Áudio. 


\subsection{1.b - ZAPPED! | 2004-2005 | Preemptive Media ${ }^{38}$}

Palavras-chave: Vigilância e Controle, Rfid, MídiaTática, Ubiqüidade;

\section{Descrição}

Zapped! é uma obra mista que envolve tanto o estudo e mapeamento da crescente implantação em massa do sistema de identificação por rádio freqüência Rfid, quanto a elaboração de dispositivos que "confundem" estes sistemas e o processo de criação colaborativa destes dispositivos, através de workshops que visam permitir que os participantes reconheçam e respondam à estas tecnologias.

Os dispositivos elaborados incluem:

- Chaveiro detector de Rfid;

- Livro de jogos, que apresenta a cronologia ilustrada do desenvolvimento e utilização do Rfid, buscando sensibilizar a percepção para a abrangência desta tecnologia;

- Etiqueta de Rfid especialmente elaborada para ser acoplada em baratas de Madagascar, capazes de se infiltrar e inserir mensagens em sistemas Rfid, provocando "rupturas" em seus códigos;

- Um vídeo que conta a história e os usos mais inusitados desta tecnologia;

\section{Objetivos}

Percebendo a crescente implantação em massa dos sistemas de restreamento Rfid, - Preemptive Media vê a oportunidade de retomar questões sobre as práticas socialmente assimiladas e aceitas de vigilância e controle e examinar o papel que as novas tecnologias desempenham na expansão das infraestruturas de vigilância. A utilização desta tecnologia está determinando novas fronteiras no âmbito da vigilância e controle, com o uso do RIFD, para aumentar a eficiência de seus sistemas em mercados onde a mão-de-obra é cara, por meio de uma ampliação no nível de

\footnotetext{
${ }^{38}$ Preemptive Media é composto pelos midiartistas: Beatriz da Costa, Heidi Kumao, Jamie Schulte e Brooke Singer.
} 
automatização, no monitoramemto supermercados, fronteiras, jardins de infância, presídios, etc. Em resposta a essa situação o Zapped! oferece aparelhos que detectam a infraestrutura de RFID e permitem a inserção de mensagens entre os dados que essa estrutura, alem de organizar e promover a sensibilização dos participantes de suas oficinas para esta estrutura. Zapped! ainda visa inserir "ruídos" e mensagens em bancos de dados utilitários de Rfid voltados para empresas que utilizam esta tecnologia para rastreamento de seus produtos, tais como o Wal-Mart.

\section{Metodologia}

O desenvolvimento da obra envolve as seguintes etapas: o desenvolvimento de dispositivos Rfid, o livro, o vídeo, os workshops e a criação de artefatos como roupas, chaveiros e dispositivos táticos acoplados em baratas especialmente tratadas.

Dessa maneira o Preemptive Media, torna acessível experimentalmente, a observação, o reconhecimento e a intervenção em sistemas de Rfid, ampliando as possibilidades de intervenções críticas em torno desta tecnologia.

- Dispositivos Rfid: o grupo conta com alguns dispositivos como, um chaveiro que detecta campos de Rfid (Fig.1), baratas de Madagscar (Fig.2) acopladas com uma etiqueta capaz de inserir informações extras nos circuitos de Rfid comuns e o desenvolvimento de algumas roupas e acessórios com estas tecnologias. Alguns destes dispositivos podem ser montados em workshops do grupo.

- Workshop: (Fig.3 e 4) o workshop é particularmente interessante, porque estende a percepção sobre o rastreamento e a gravação de dados em um novo formato. Utilizando os dispositivos Rfid, como chaveiros detectores que os próprios participantes fabricam, os workshops do grupo levam os participantes a entender e operar dentro do processo rastreamento. Através do workshop se produz momentos de sensibilização e engajamento, que tornam tangíveis o acesso, a produção e a interferência nesta tecnologia.

- O livro: (Fig. 5) é um livro didático de jogos, que inclui uma linha do tempo ilustrada sobre o desenvolvimento do Rfid, uma pequena taxonomia de termos relevantes e um jogo onde os participantes tentam identificar produtos 
comuns identificados com Rfid. Através desses artefatos, é explicada e detalhada ao público, a forma como são implantados os sistemas de Rfid na agenda de segurança nacional dos EUA e nas operações industriais de produtos de consumo e até mesmo em documentos pessoais, tais como carteiras de motorista.

\section{Meios de produção e tecnologias envolvidas}

O projeto Zapped! desenvolve meios de produção autônomos, envolvendo predominantemente o meio tecnológico do Rfid. O sistema é composto por:

- Etiquetas Rfid (Fig.6): (também chamadas de Transponders): a grande maioria destas etiquetas consiste em um microchip de silício anexado a uma antena, cada microchip contém um número serial, como um código de barras, e armazena um grande numero de dados que são transmitidos pela antena via freqüência de rádio para os leitores.

- Leitores(Fig.7): parecidos com scanners de códigos de barras, os leitores são normalmente conectados a um computador pessoal com servidor. São os leitores que fazem a conexão entre as etiquetas Rfid e os bancos de dados. Os leitores podem também ser portáteis, com baterias e micro-computadores inclusos para garantir a mobilidade destes aparelhos.

- Banco de dados: o banco de dados armazenam os dados das etiquetas e constantemente anexam novas informações.

\section{Reprodutibilidade tecnológica da obra}

Essa tecnologia consiste em etiquetas eletrônicas com microprocessadores sob as formas de adesivos, cartões ou mesmo chips que podem ser implantados sob a pele. Como o grupo previu em meados de 2004, houve a implantação massiva de tecnologias de Rfid. No ano de 2007, em São Paulo, houve um projeto para a implantação de etiquetas RFID para fins de fiscalização em toda a frota de veículos do município, bem como para localização de veículos roubados; cada carro recebeu um chip que é lido por antenas espalhadas pela cidade. Desta forma, é também possível rastrear os percursos de cada um dos milhões de veículos da cidade. Os passageiros do transporte público paulistano, por sua vez, já podem ser rastreados pela tecnologia RFID: o cartão utilizado 
para integrações também faz uso da mesma tecnologia e é muitas vezes pessoal cadastrado com dados de seu usuário - sendo capaz de indicar quais meios de transporte foram utilizados e seus deslocamentos cotidianos.

\section{Modos de extroversão}

Se trata de um produção participativa de dispositivos, criados através dos workshops, performances com mídias táticas a fim de inserir informações extras nos circuitos operantes de Rfid; Zapped! acontece tanto nos workshops e performances em galerias, mas principalmente nos momentos de interferência, seja de detecção ou de incisão nos sistemas comerciais operantes de Rfid;

\section{Imagens: ${ }^{39}$}

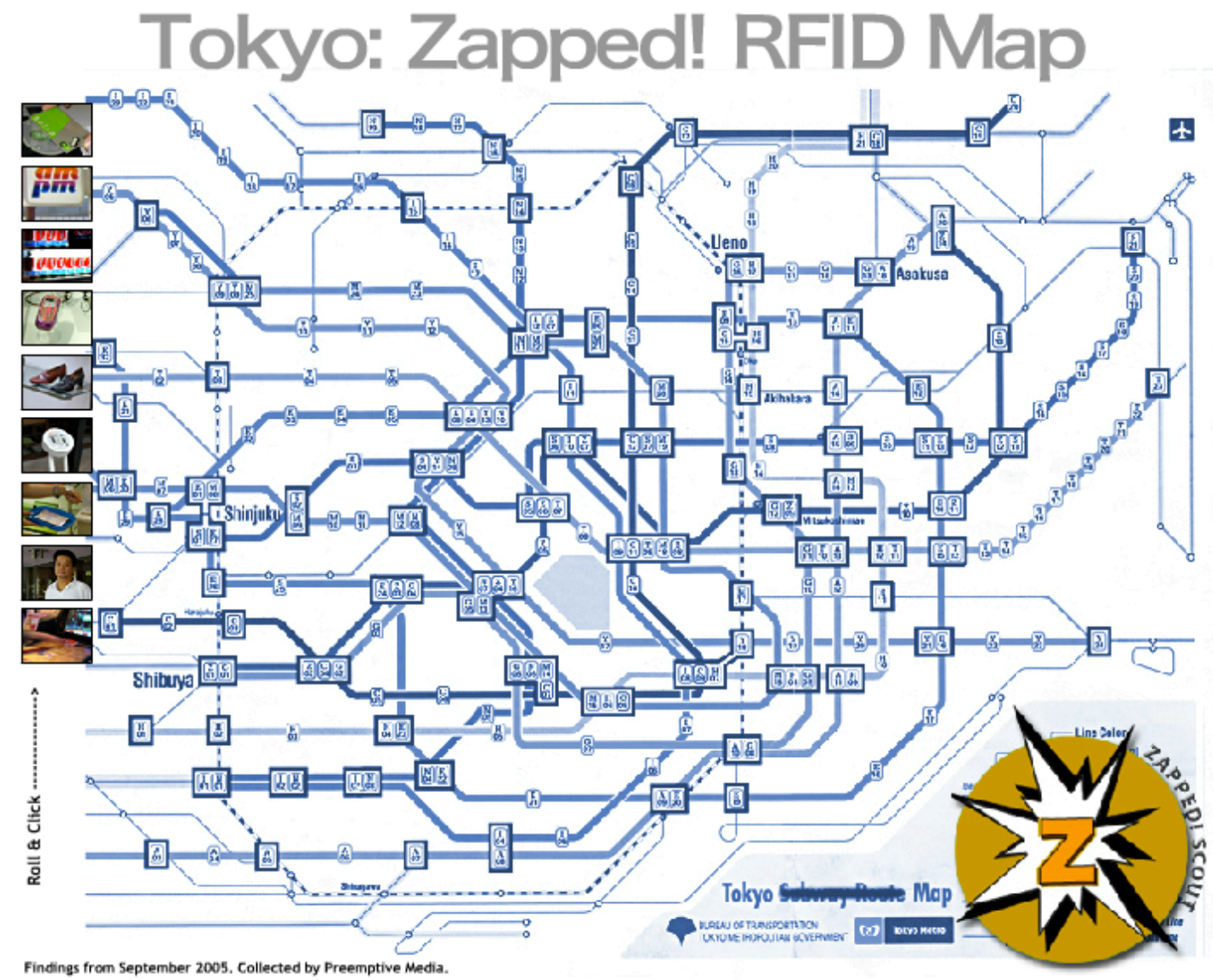

Fig. 22 - Mapeamento interativo das redes de Rfid na cidade de Tokyo ${ }^{40}$

\footnotetext{
${ }^{39}$ Imagens disponíveis em: http://preemptivemedia.net/zapped/index.html. Acesso em: 12/02/2016

${ }^{40}$ Mapa interativo disponível em: http://www.preemptivemedia.net/zapped/tokyo.html Acesso em: 02/07/2015
} 


\section{RFID: How it Works}

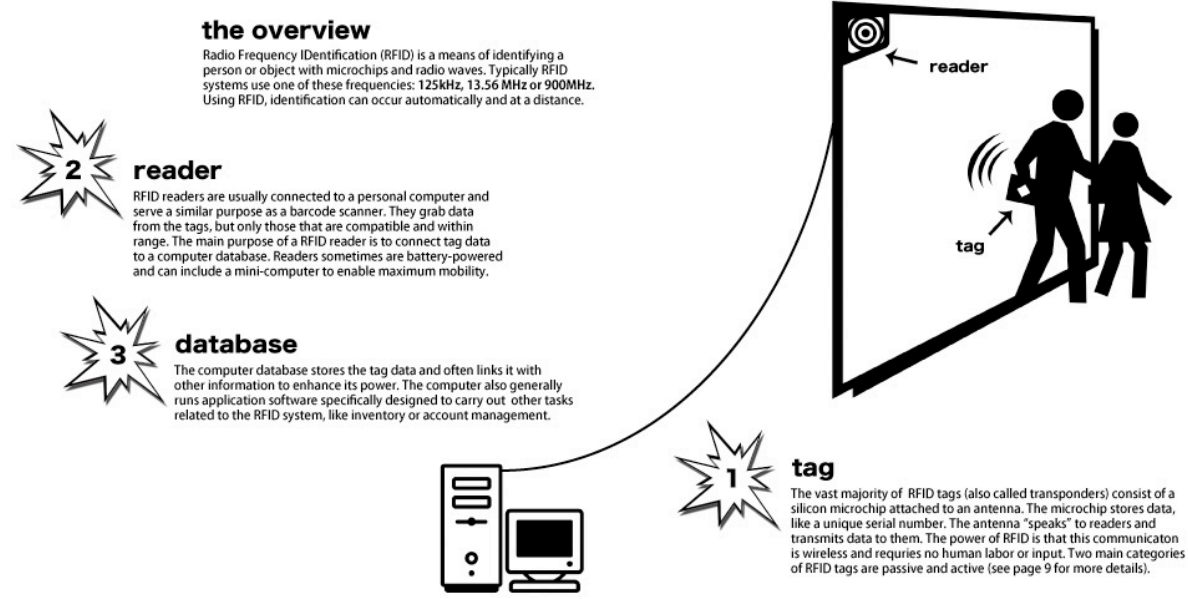

Fig. 23 - Manual realizado pelo coletivo para as oficinas
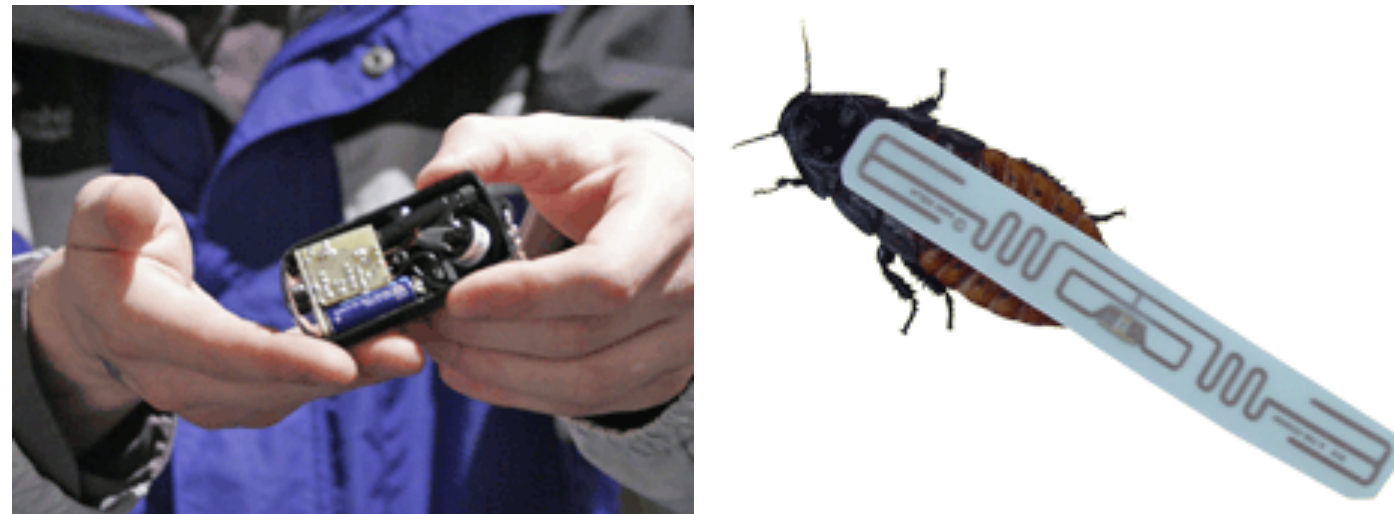

Fig.24 (esq.)- Chaveiro, Fig.25 (dir.) - Barata de Madagascar (Gromphadorhina portentosa)
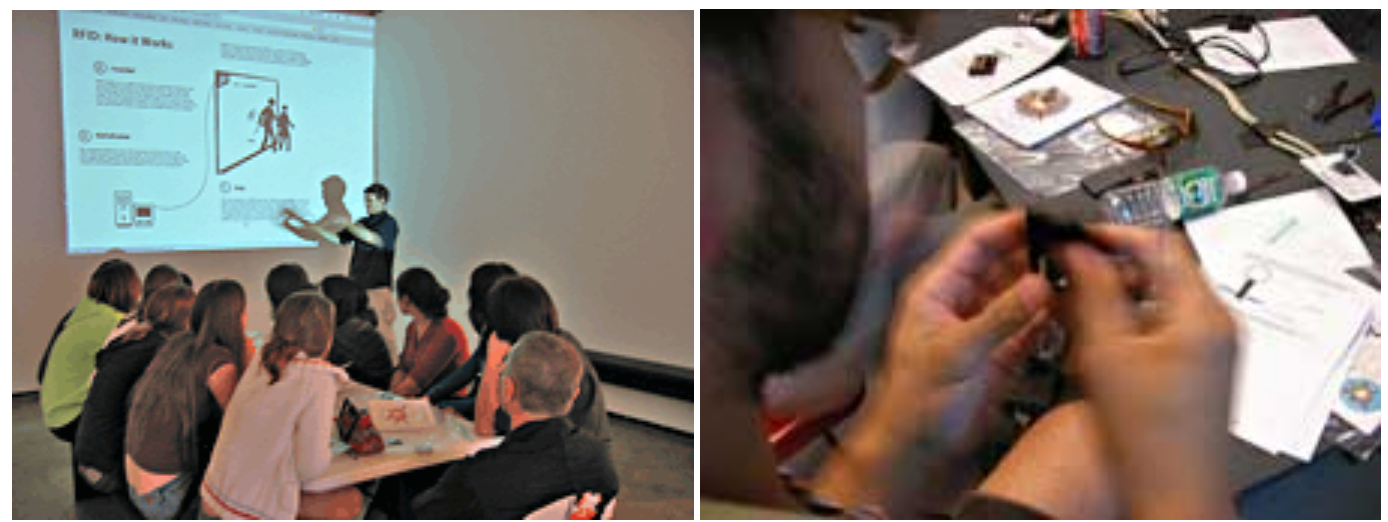

Figura 26(esq.) e 27(dir.) - Workshop 

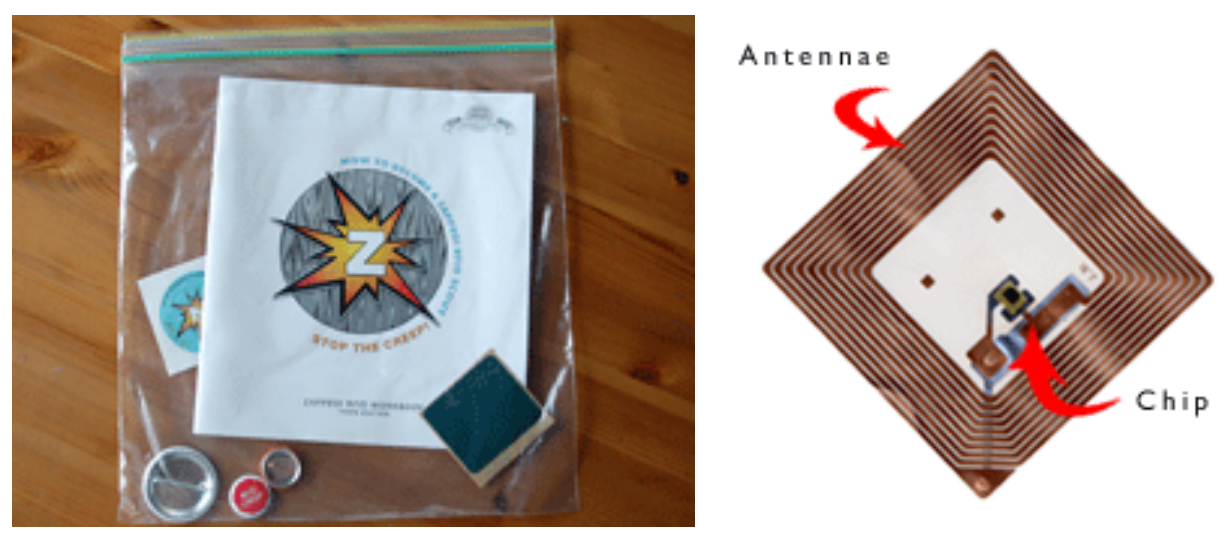

Figura 28(esq.) - Livro; Figura 29(dir.) - Etiqueta de Rfid
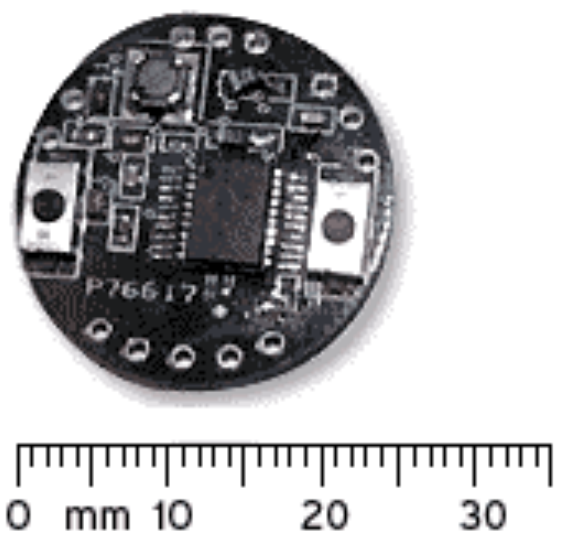

Figura 30(dir.) - Leitor Rfid 


\subsection{1.c - Tatical Sound Garden | 2007 | Mark Shepard}

Palavras-chave: processos colaborativos de mapeamento e troca livre de dados, licenças copyleft e propriedade intelectual;

\section{Descrição}

Tatical Sound Garden (TSG) é uma plataforma em software livre de compartilhamento de arquivos sonoros, que se instala em zonas de alta densidade de sinais Wi-fi (hot zones) para "implantar" jardins sonoros de uso participativo. Estas "plantações" são mapeadas e associadas à coordenadas espaciais, assim cada local de convergência destes arquivos se torna uma espécie de mapeamento sonoro local, contendo sons dos arredores, musicas, falas, etc. Os participantes, munidos de fones de ouvidos e dispositivos móveis com acesso wi-fi acessam estes arquivos sonoros e podem por sua vez contribuir "subindo" novos arquivos e ampliando assim as camadas auditivas locais.

\section{Objetivos}

Dentre os principais objetivos da obra podemos citar a demarcação de zonas sonoras compartilháveis dentro do espaço urbano, que possam ser ampliadas com a contribuição de cada usuário. Além da produção de paisagens sonoras específicas de cada ponto de compartilhamento, gerando assim uma especificidade sonora local.

Com esta ação Shepard pretende possibilitar um urbanismo propagativo, constituído a partir da participação colaborativa de seus usuários.

\section{Metodologia, meios de produção e tecnologias envolvidas}

TSG é um programa em software livre, ou seja aberto e pode ser aprimorado conforme a necessidade. Para acessar os jardins sonoros, é necessário fazer o login e o upload de sons contidos no dispositivo de cada usuário, em seguida é possível acessar o ambiente sonoro de cada área.

De acordo com a localização do usuário no instante do upload, se determina as coordenadas espaciais de localização do arquivo, portanto este upload é tanto físico como em rede. 0 raio de abrangência dos arquivos sonoros a partir daquela localização determina a espacialidade, em que se insere o jardim sonoro. Assim envolve-se tanto o 
acesso em rede via wi-fi quanto a sua localização no espaço urbano via GPS. O que atribui espacialidade e contexto local aos jardins sonoros.

O contexto tecnológico da obra necessita, portanto, de dispositivos móveis com fones de ouvido (ou não) e acesso às redes Wi-fi e GPS, necessita a partir desse acesso, a conexão com a Internet e seus múltiplos servidores, a gravação e o upload de arquivos mp3 na plataforma do Tatical Sound Garden. É possível ainda através dos dispositivos anexar mensagens à cada arquivo de áudio.

\section{Reprodutibilidade tecnológica}

A reprodutibilidade desta obra se produz no mínimo em três instâncias:

Software Livre: O principal fator de reprodutibilidade desta obra, se centra no fato de a plataforma do TSG ser escrita em código livre, o que permite a reprodução e alteração de seu código, bem como o acesso descentralizado à esta plataforma.

Compartilhamento de áudio: aqui outro deslocamento que se produz na obra é o compartilhamento livre de arquivos sonoros, descentralizados das leis de propriedades autorais.

\section{Modos de extroversão}

O obra é feita para o uso participativo especialmente no espaço público urbano, potencializando as relações descentralizadas de trocas de arquivos, associados a uma localidade específica .

\section{Imagens}




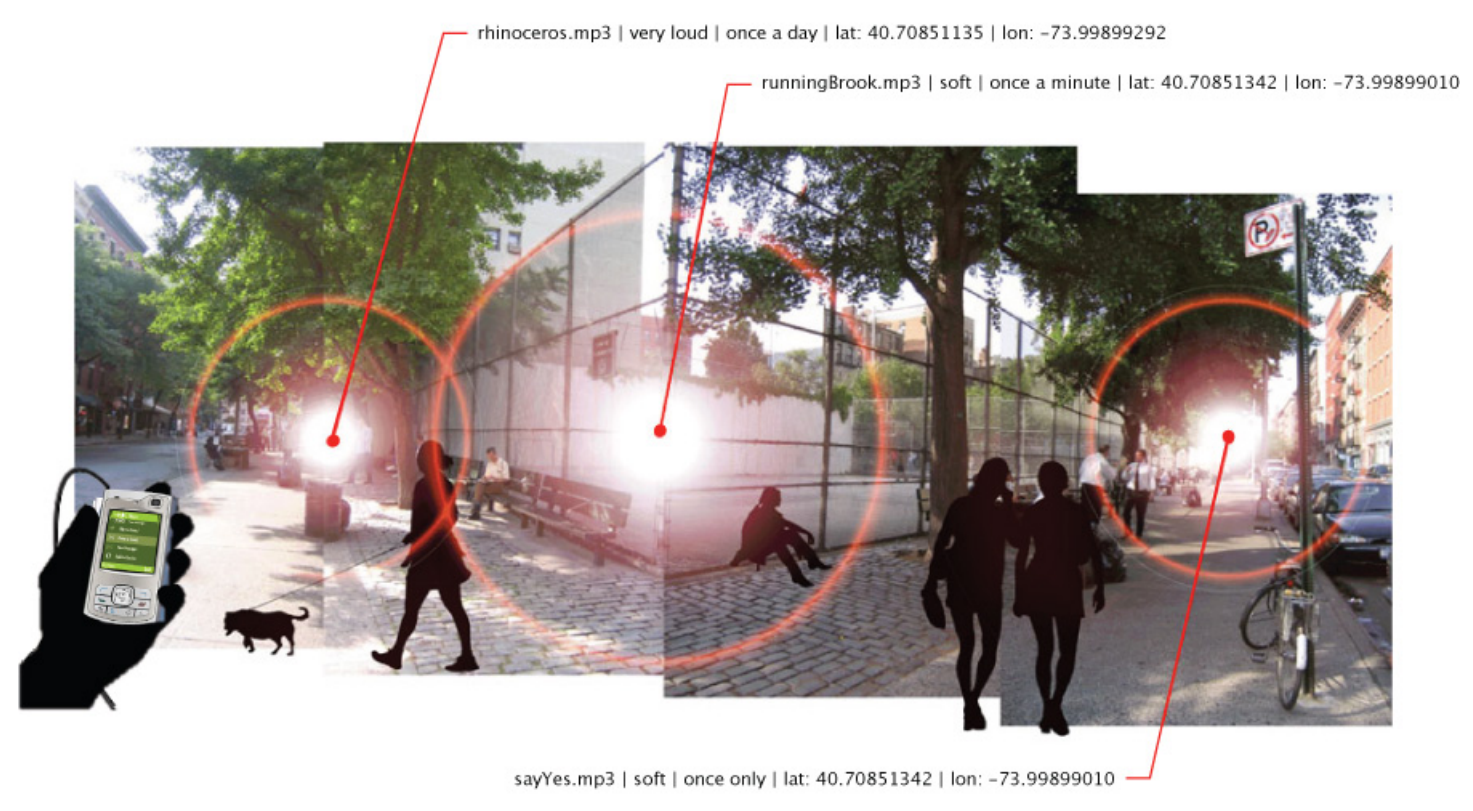

Figura 31 - Posicionamento do Sound Garden

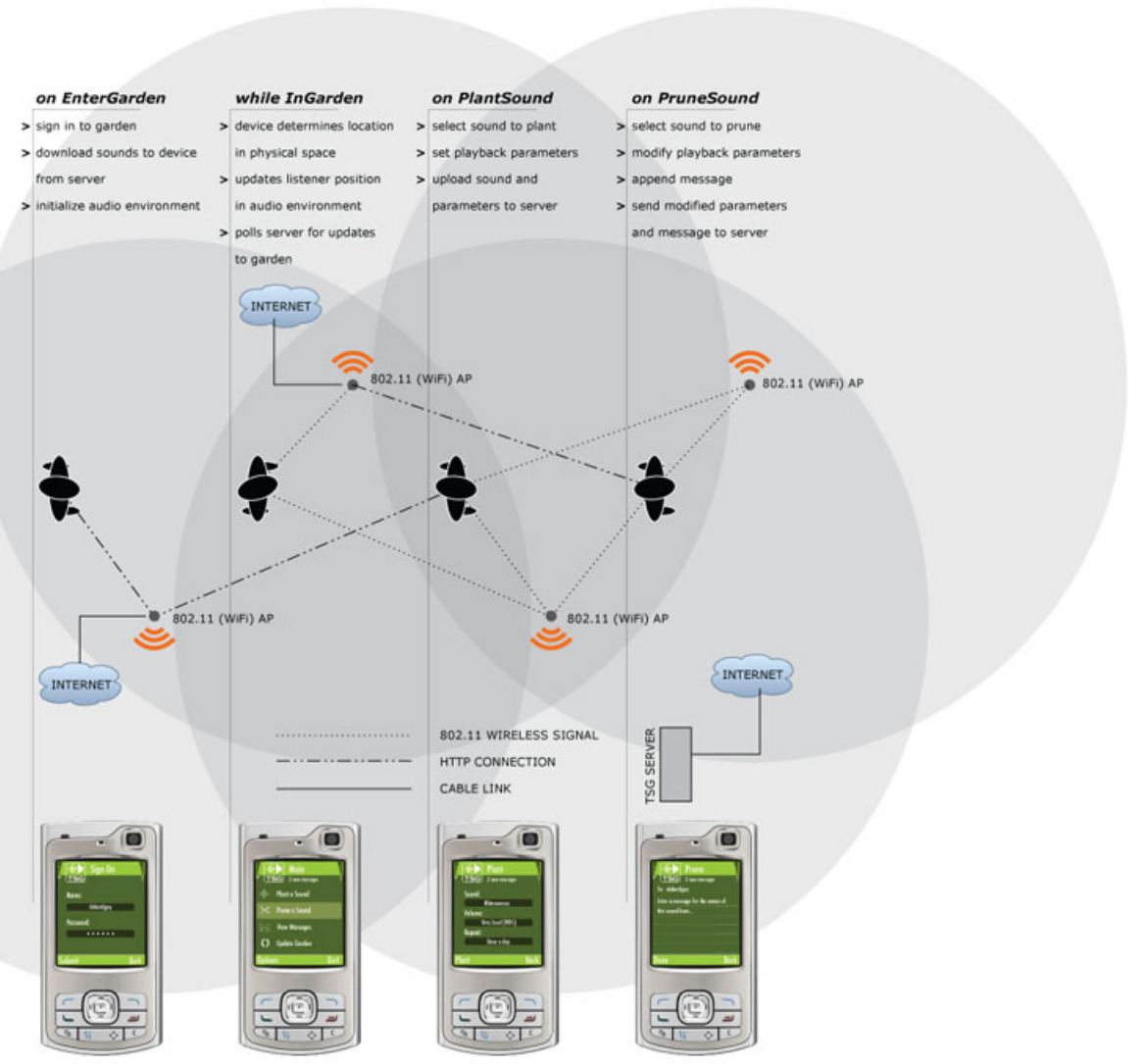

Figura 32 - Esquema de funcionamento do Sound Garden; 


\subsection{1.d - TRANSBORDER IMMIGRANT TOOL | 2007 | Electronic Disturbance Theater ${ }^{41}$}

Palavras Chave: Vigilância e controle, Mídia táticas, Pervasividade e Ubiqüidade das pós-mídias;

\section{Descrição}

A cada ano, milhares de pessoas tentam atravessar o deserto que compõe a fronteira entre Estados Unidos e México. Centenas desses imigrantes perdem a vida, devido à incapacidade de discernir onde eles estão em relação ao ponto de partida e qual a direção seguir para chegar a seu destino em segurança. Os perigos dessa cruzada, para além da questão política, do encerramento de fronteiras, vem da transposição desse deserto, da falta de referências espaciais e suprimentos.

O Transborder Immigrant Tool promove a demarcação geológica das melhores rotas para se atravessar esse deserto, bem como pontos com comida e água, postos policiais que poderiam identificar os imigrantes, lugares de hospitalidade para os imigrantes. Esta demarcação (tageamento) do deserto entre fronteiras é feita de forma colaborativa entre usuários que já fizeram a travessia e identificaram potenciais zonas de risco.

\section{Objetivos}

O objetivo do projeto é ajudar a reduzir o número de mortes ao longo da fronteira , desenvolvendo uma ferramenta de navegação instalada em um aparelho de telefone celular comum (Fig.1), que ajuda os migrantes localizar recursos que salvam vidas no deserto, como água, suprimentos e cabines de vigilância e controle de fronteiras.

\section{Metodologia}

Este projeto de arte foi desenvolvido em cinco etapas:

- Mapeamento da fronteira México/Estados Unidos: em ambos os lados da fronteira, a fim de encontrar as coordenadas exatas necessárias para ancorar as triangulações que marcam os pontos de localização para o Transborder Immigrant Tool.

\footnotetext{
${ }^{41}$ Electronic Disturbance Theater é composto por: Micha Cárdenas, Amy Sara Carroll, Ricardo Dominguez, Elle Mehrmand and Brett Stalbaum
} 
- Levantamento de estruturas físicas: Pesquisa sobre redes e infraestruturas transfronteiriças atuais e preventivas, tais como, atividades da segurança interna, projetos de segurança de fronteira, patrulha fronteiriça e pontos de água/alimentos estabelecidos pelas comunidades de apoio ao longo da fronteira - com o objetivo de melhorar as probabilidades de segurança imigração e determinar qual dos caminhos computacionalmente mediados são os mais seguros a seguir.

- Desenvolvimento do código do Tranborder Immigrant Tool e teste de coordenadas GPS para desenvolver a interface e instruções em espanhol e inglês.

- Teste do algoritmo pelos investigadores e artistas convidados. Prôs-se primeiro caminhar para o sul, para o México e em seguida, caminhar de volta para o norte nos EUA, na tradição das caminhadas de Richard Long, gestos psicogeográficos situacionistas e a obras-fronteiras do artista Heath Bunting.

- Distribuição do Transborder Immigrant Tool para comunidades de imigrantes nos dois lados da fronteira. Cada ferramenta é demarcada como um projeto de arte pela Electronic Disturbance Theater e pelo Lab.Bang (bang.calit2.net) - todos os usuários foram solicitados a retornar com 0 Transborder Immigrant Tool uma vez que chegassem em segurança um ponto de ancoragem final para fazer a atualização do dispositivos, com novos dados possíveis encontrados na travessia e posterior distribuição. (Fig. 2)

\section{Meios de produção, reprodutibilidade e tecnologias envolvidas}

A versão beta do Transborder Imigration Tools foi programada na plataforma J2ME (que é uma linguagem Java atualizada, aplicada em dispositivos móveis, orientada para o fácil acesso a internet) e implantada em um telefone celular i455 Motorola (Fig. 1), com GPS ativado, relativamente barato (na época de sua implantação custava US \$ 40).

As tecnologias espaciais de georreferenciamento GPS (Sistema de Posicionamento Global) têm permitido uma relação inteiramente nova com a paisagem que toma forma nas aplicações para a simulação, vigilância, alocação de recursos, gestão de redes de cooperação e de modelagem de padrão pré-movimento (como o Virtual Walking Algorithm) um algoritmo que traça e sugere percursos potenciais para caminhantes. 
Com o surgimento de vários sistemas de informação geoespacial distribuídos (como o Projeto Goggle Terra, por exemplo), GPS (Global Positioning System) e do desenvolvimento de pedestrianismo Algoritmo Virtual pelo artista Brett Stalbaum agora é possível desenvolver ferramentas para imigrantes, implementadas e distribuídas em telefones celulares.

\section{Modos de extroversão}

Transborder Immigrant Tool é uma plataforma colaborativa, onde dados podem ser atualizados constantemente através da participação dos usuário. Dos dados que podem ser inseridos destacam-se o posicionamento das cabines de vigilância, fontes de abastecimento de água e condições territoriais específicas. Esta plataforma possibilita a integração colaboração e troca de informações entre grupos de imigrantes.

\section{Imagens}

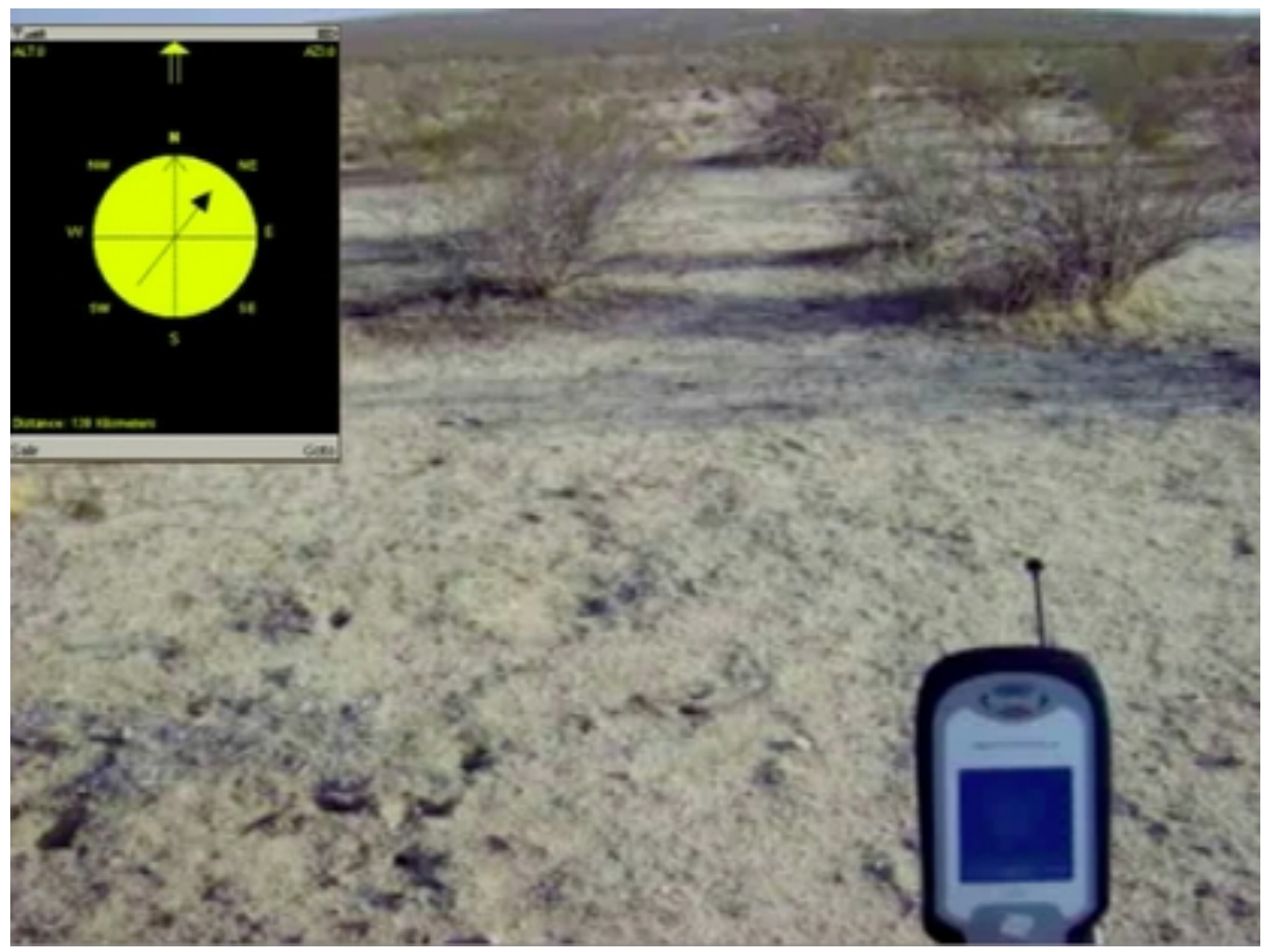

Fig. 33 - Interface do aplicativo em funcionamento 


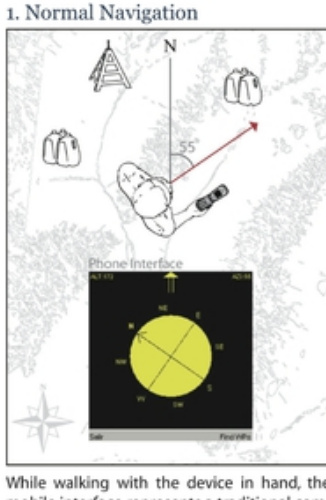

While walking with the device in hand, the pass interface

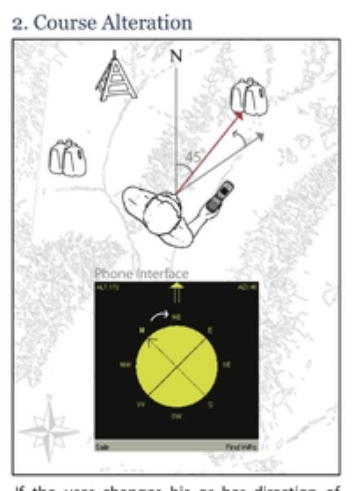

If the user changes his or her direction of

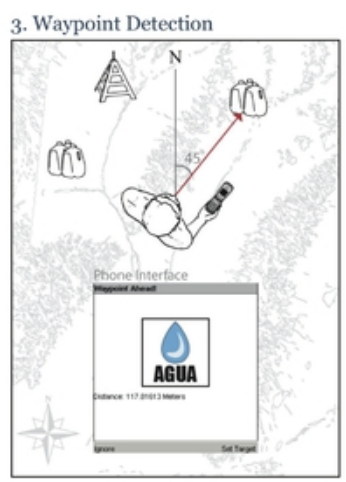

When the direction of travel is equal to angle between ine north and the position or some information pertaining to the resource ahead

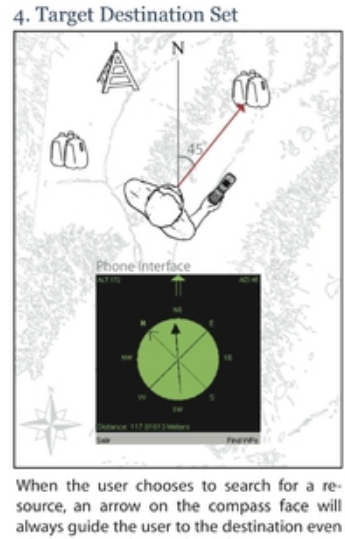
ays guide the user to the destination even

Fig. 34 - Interface e funcionamento do Transborder Immigrant Tool 


\subsection{1.e - MEGAFONE.NET | 2004-2015 | Antoni Abad}

Palavras-Chave: mídias, acesso e visibilidade digital; compartilhamento;

\section{Descrição}

A rede Megafone. net é uma plataforma que busca ampliar a visibilidade e a autorepresentação de grupos urbanos, em risco de exclusão social. A obra agencia processos comunicacionais em rede, associados a uma localidade específica, através do uso de mídias locativas. Esta rede é resultado e ampliação de um projeto inicial de produção e registro de experiências urbanas de um grupo de taxistas da cidade do México, chamado Zexe.net, que posteriormente se ampliou e se tornou o Megafone.net. O Megafone.net é também utilizado por: "Ciganos (Léon e Lleida - Espanha, 2005); Prostitutas (Madri, 2005); Imigrantes nicaraguenses (Costa Rica, 2006); Pessoas com mobilidade reduzida (Barcelona, 2006), Motoboys de São Paulo (2007), Pessoas com mobilidade reduzida (Genebra, 2008); Migrantes e ex-guerrilheiros (Colômbia, 2009); Jovens refugiados Sarahauis (Argélia, 2009) e pessoas cegas e com visão reduzida (Barcelona, 2010)" (ALZAMORA, 2010. p.68) ${ }^{42}$. Destes o grupo mais duradouro do projeto é o coletivo brasileiro Canal Motoboy que integra a proposta desde 2007 até hoje.

\section{Objetivos}

A plataforma busca que grupos em risco de exclusão social tenham sua voz e presença ampliadas ao utilizar a rede para expressarem suas experiências cotidianas.

Os participantes transformam estes dispositivos móveis em megafones digitais, para assim amplificar suas vozes individuais e coletivas, em geral ignoradas ou desfiguradas pelos meios de comunicação hegemônicos.

Esse registro se dá via sons e imagens capturadas via celulares e associadas a uma localização via Gps. O processo de midiatização de percursos pessoais em espaços urbanos variados, expressa experiências midiáticas fundamentadas na vivência cotidiana. Cada postagem feita pelos participantes pode ser comentada via texto e áudio, conectando múltiplas camadas de percepção do espaço urbano vivido. Esta proposta estética tensiona politicamente espaço fundado sobre relações sociais

\footnotetext{
${ }^{42}$ ALZAMORA, G e CARVALHO, R. S. Relatos do cotidiano no Canal Motoboy: Dimensões Estética e Política da Experiê ncia Urbana. In: Revista Eco-Pós. volume 14 número 01 - p.67-81. Rio de Janeiro: UFRJ, 2010.
} 
excludentes e é capaz de, estética e midiaticamente, potencializar e ampliar a visibilidade destes grupos.

\section{Metodologia}

- Acesso e formação de grupos: o modo de funcionamento de cada grupo do Megafone.net tem uma estrutura semelhante. O contexto de cada grupo é definido pelos participantes e para produzir e acessar uma nova plataforma, é feita uma reunião inicial, com os coordenadores do projeto, onde se define quais serão os canais coletivos produzidos e o objetivo de cada canal.

- Interface: a interface do Megafone.net foi elaborada para facilitar tanto o carregamento dos arquivos em tempo real, quanto o posicionamento geográfico dos arquivos produzidos pelos participantes, organizando bancos de dados que organizam e retratam a experiência urbana na perspectiva de cada coletivo.

- Estruturação: Em todos os grupos é possível perceber a estruturação de quatro grandes áreas que permeiam toda a rede: seres, atividades, espaços e objetos. Estas áreas foram criadas pela equipe de produção do Megafone.net e são associadas a 44 tags iniciais que "organizam" ou dispõe em categorias estas áreas, com a utilização constante do grupo, essas categorias se ampliaram consideravelmente, também conjunto de tags se ampliou consideravelmente com a inserção de cada grupo designando suas singularidades.

Embora esta produção seja colaborativa, cada um dos participantes tem acesso a um login específico, assim, dentro de um mesmo grupo, se negocia alternadamente quem será o emissor ativo de arquivos, em determinado momento. Cada arquivo produzido individualmente é sujeito a interação dos outros membros através da troca de mensagens e diálogos em tempo real.

A interface aceita imagens, vídeos e áudios que são automaticamente associados a uma geolocalização e a uma tag específica dentro desta rede. Tags são denominações de lógicas de transmissão e organização de conteudos específicos dentro de um contexto. Por exemplo, para o coletivo de motoboys em São Paulo ou taxistas no 
México a tag \#trânsito pode associa os arquivos produzidos às condições de tráfego urbano destes participantes.

\section{Meios de produção, reprodutibilidade e tecnologias envolvidas}

O projeto envolve basicamente um site que possibilita e organiza o carregamento de arquivos a partir de dispositivos móveis e os associa a um grupo, uma localização e uma temporalidade. Cada arquivo é relacionado a um usuário e pode-se interagir com ele através de mensagens ou comentários de áudio. Ou mesmo posteriormente o próprio grupo pode editar as informações levantadas no site do grupo.

\section{Modos de extroversão}

Trata-se se uma obra colaborativa, que acontece simultaneamente no cotidiano vivido e no seu espelhamento pelo site do projeto. Tal espelhamento é antes um espelhamento amplificado, associado a tags (demarcações), comentários, mensagens e em última instância a um grupo, que atravessa singularidades locais e as amplia.

\section{Imagens}

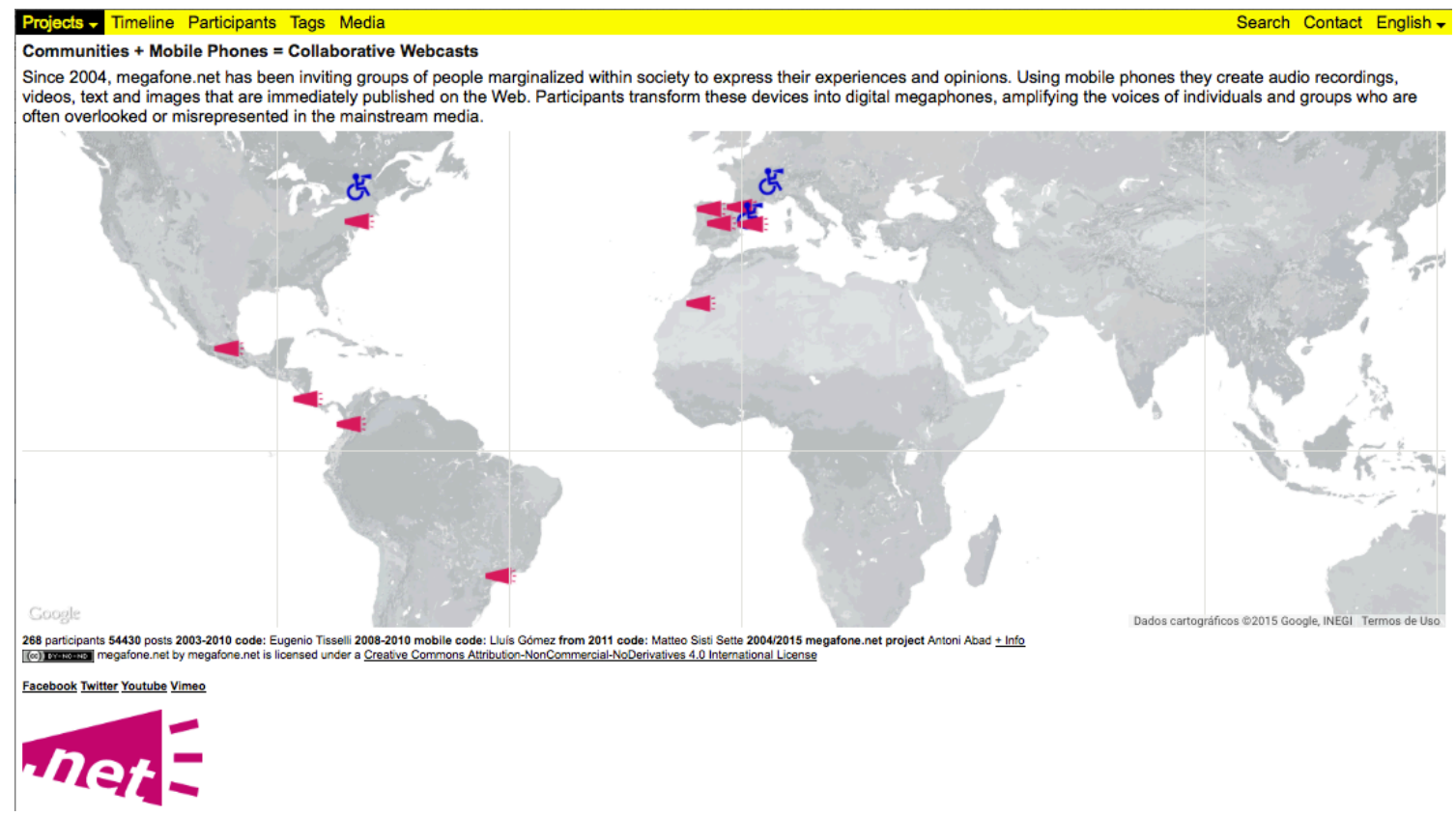

Fig.35 - Localização de projetos do Megafone .net 
Projects - Timeline Participants Tags Media

Search Contact English -

adult association bar bravo building children dia a dia family female home house impassables leisure

male mates meeting park pavement pictures shop stairs steps street tochnology to move tafic vehicle work work young

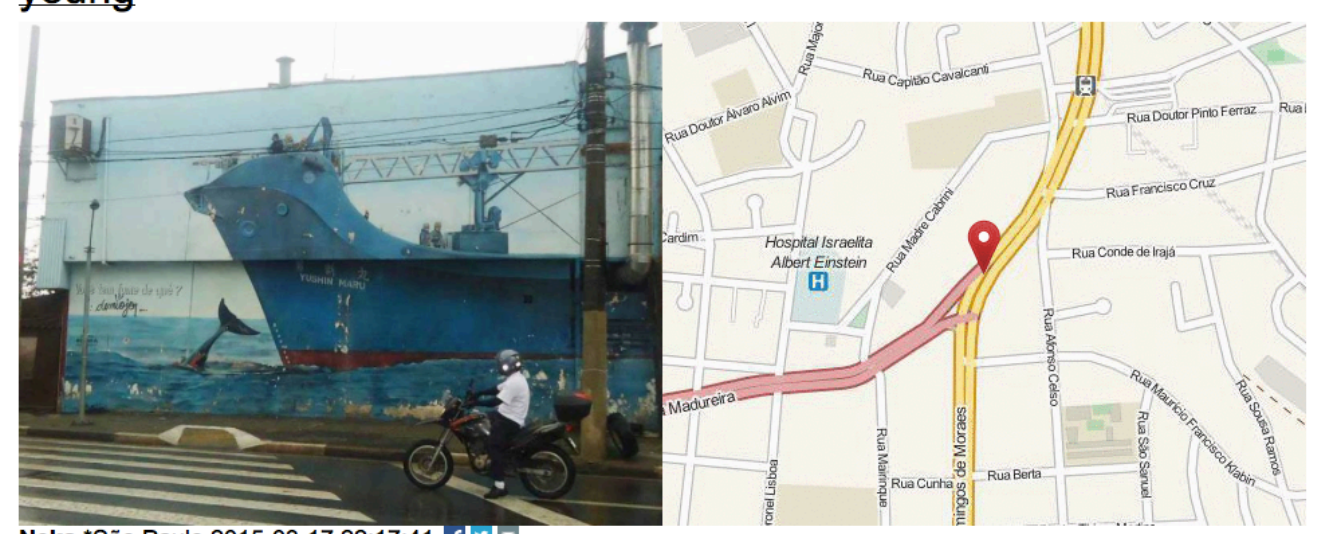

Neka *São Paulo 2015-03-17 22:17:41 f f 비보

\#dia a dia \#bairros

Vila Mariana

1 comment

Fig.36 - Página dos motoboys Megafone.net

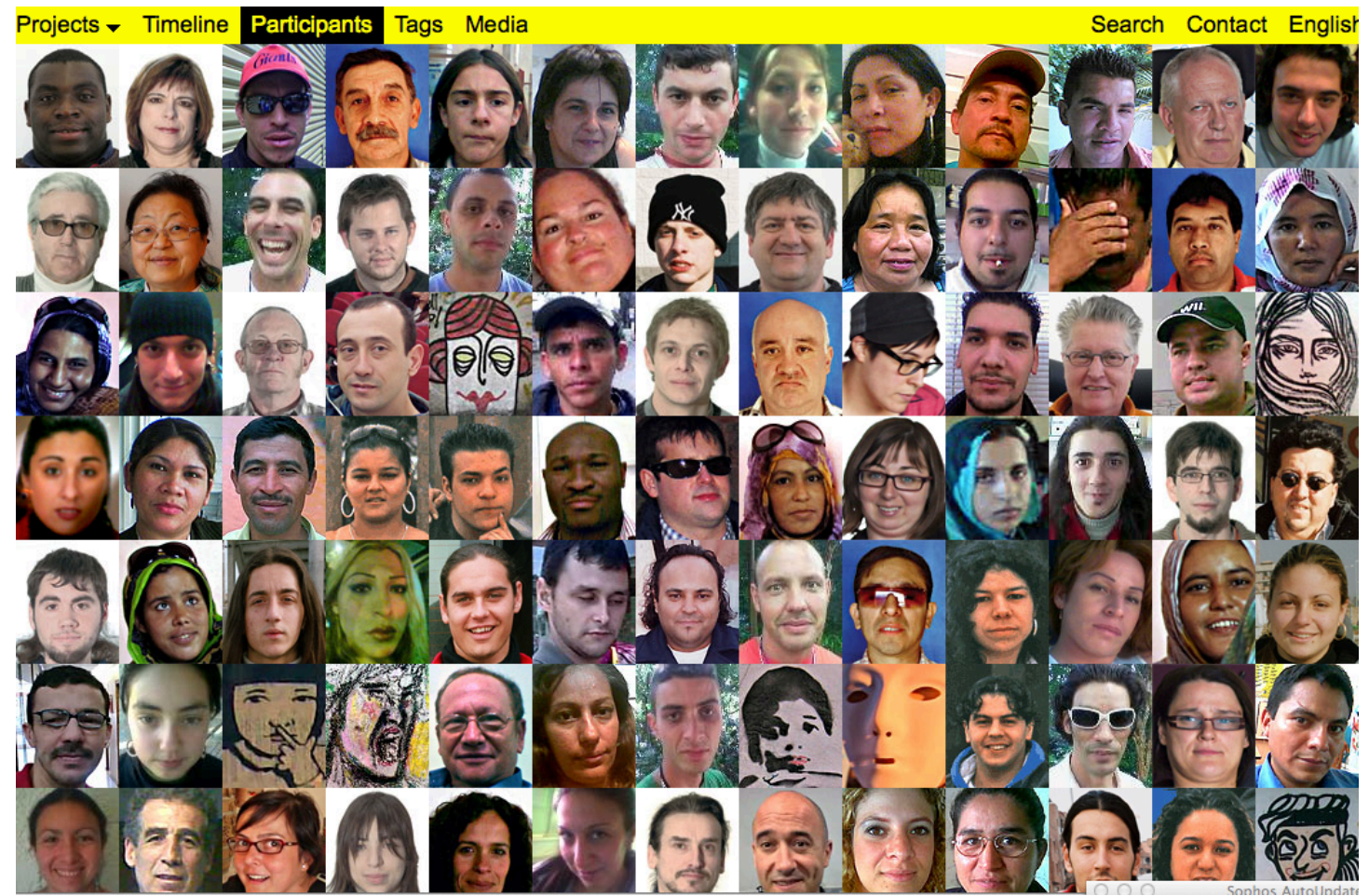

Fig.37 - Página Inicial do site Megafone.net 


\subsection{2 - Relações externas das obras}

As obras mapeadas nesta dissertação operam modos muito específicos de agenciamentos estéticos da mobilidade através das mídias locativas. A mobilidade é compreendida aqui, como acoplamento entre o caminhar mediado pelos dispositivos móveis, pelas formas de sentir e perceber e pelos vínculos e cortes de significação que se desdobram a partir desta mediação, tornando possível a produção de lugares e corpos conectados.

O caminhar, adotado como prática estética, atravessa a modernidade desde 0 flâneur de Baudelaire na virada do séc XIX, atravessando o século XX com a deambulação surrealista, as explorações urbanas de Walter Benjamin, a deriva situacionista e os percursos da Land-Art com Richard Long e Robert Smithson a partir da década de 60 (BASSETT, 2004, p.398) ${ }^{43}$. Mais recentemente, na década de 90, com o grupo Stalker em Roma com Francesco Careri e as psicogeografias londrinas apontadas pelo autor lan Sinclair. No Brasil, aproximações são apontadas pela autora Paola Berenstein Jacques, com a Experiência $n^{\circ} 2$ (1931) de Flávio de Carvalho e Delírio Ambulatorium (1978) de Helio Oiticica.

O Flâneur é uma figura nascida na modernidade, um contraponto à figura do burguês, que dedicava grande parte do seu tempo ao mundo dos negócios. O processo de urbanização das cidades europeias fomentado pela industrialização nos séculos XVIII e XIX teve como consequência o aumento das multidões. Os modos fabris de produção, as linhas de montagem e a ideologia do "tempo é dinheiro" foram capazes de reconfigurar o cotidiano dos cidadãos, de suas vidas, seus tempos e espaços. Em meio a este processo a flânerie se estabeleceu como experiência própria daquele que perambulava e observava as ruas, numa espécie de contraponto ao ritmo crescente da vida nas cidades industriais, sem objetivos senão o de sentir as novas dinâmicas da cidade, as relações entre os fenômenos urbanos das multidões e sua experiência vivida. Para Baudelaire a multidão é a usina de força do flâneur, uma figura que está em todos os lugares e ao mesmo tempo em nenhum lugar. Entre todos, porém sozinho, dividido entre o encantamento e o temor da cidade.

\footnotetext{
${ }^{43}$ BASSETT, KEITH. Walking as an Aesthetic Practice and a Critical Tool: Some Psychogeographic Experiments. In: Journal of Geography in Higher Education, Vol.28, N³, 2004, p.397-410.
} 
Já no século XX Walter Benjamin, retorna à figura do flâneur de Baudelaire em seu texto inacabado The Arcades Project, como um ponto de partida para a análise do impacto da vida urbana sobre a psique humana, na modernidade. Os poemas de Flores do Mal revelam o olhar transitório que o flâneur dirige à Paris e à vida pública, que se desenrola sob os arcos de aço e vidro das galerias. Aqui as Arcadies de Paris se tornam um ponto-chave, uma imagem do fenômeno transitório da modernidade. De fato para Benjamim a modernidade é uma transição, sobre a qual ele lança um olhar ambivalente, que busca resgatar a herança cultural do passado para entender o presente e pressentir um possível futuro. (BASSETT, 2004, p.398)

A prática de apreender o espaço urbano pela ação do andar, que se origina na ideia do flâneur também vai percorrer o dadaísmo, o surrealismo e o situacionismo, sob a forma de visita Dadá, de deambulação e de deriva, Francesco Careri em Walkscapes (2009) aponta as aproximações históricas e ideológicas existentes entre a transição dos movimentos Dadá, Surrealista (1924-1966) e o movimento da Internacional Situacionista (1957-1972) que colocam o caminhar como prática estética.

O movimento Dada foi formado a partir do horror às atrocidades da guerra, ao nacionalismo e ao pensamento racionalista que conduziram o mundo ao horror da primeira guerra. Os dadaístas constituem um movimento de negação dos valores da arte ocidental, ganhando o status de anti-arte e materializando o desejo de criticar e questionar o sentido de sua época. A primeira "anti-caminhada" Dadá foi realizada na igreja abandonada de Saint Julien Le Pauvre, em abril de 1921. No dia marcado para a realização do evento choveu e poucas pessoas apareceram. Mais tarde Breton recordaria esta ação como sendo um fracasso generalizado: "Não basta haver passado das salas de espetáculo ao ar livre, para acabar de uma vez, com as voltas de Dadá sobre si mesmo." (CARERI, 2009 apud. BRETTON, p.68). Apesar destas palavras, esta primeira visita será recordada como a ação mais importante do Dadá, sobre a cidade.

Há nas incursões dadaístas e deambulações surrealistas nesta 'saída' das salas de espetáculos para as ruas, com caminhadas ao ar livre, um feito seminal que ganharia força na década de 60 , com os percursos da Land Art e as derivas situacionistas marcando uma transição nos modos de significar, produzir e fazer circular a linguagem da arte. Ademais é a partir das visitas Dadá e da deambulação surrealista que se busca o caminhar como transição da representação do movimento para a construção de uma ação estética que se fundasse na realidade da vida cotidiana, uma ruptura com a 
linguagem de representação na arte. Em 1961 Tzara declarou que o Dadaísmo estava decididamente contra o futuro, uma menção clara às representações utópicas e hipertecnológicas do futurismo. Para ele é "no presente que se encontram todas as classes de universos possíveis"(CARERI, 2009, p. 69) e, dessa forma, a cidade se criava no cotidiano banindo todas as formas de representações utópicas futuristas.

O dadaísmo buscava constituir um espaço estético calcado no cotidiano, abandonando as consagradas formas de representação e apontando para a intervenção direta no espaço público urbano. Ao passo que nesta mesma época o surrealismo adotava o caminhar como prática mais "natural à conduta humana" (CARERI, 2009, P.90) como um meio para descobrir o "líquido aminiótico da cidade", ou seja, a zonas inconscientes da cidade, que escapam ao planejamento urbano, que não podem ser expressas ou traduzidas para as representações tradicionais da arte e do espaço.

A primeira experiência de deambulação realizada dentro do movimento surrealista, ocorre em maio de 1924, quando um grupo formado por Breton, Louis Aragon, Max Morise e Roger Vitrac decide ir de trem de Paris à Blois, cidade escolhida ao acaso em um mapa, e prosseguir a pé pelas cidades de Sologne, Salbris, Gien e Cour-Chevigny até chegarem à cidade de Romorantin. Foram 4 dias seguidos de passeios a pé, que Breton descreve como "exploração até os limites entre a vida consciente e a vida sonhada". As deambulações passaram, desde então, a ocorrer nas zonas suburbanas de Paris, a fim de sondar as partes inconsciente da cidade que estava escapando das transformações burguesas.

Os situacionistas se constituem na fusão de participantes do Dadaísmo, do Futurismo e de movimentos posteriores de vanguarda como Internationale Lettriste, o International Movement for an Imaginist Bauhaus e a London Psychogeographical Association num mesmo movimento denominado Internacional Situacionista, em 1957 na Itália. A essência ideológica do movimento, relatada no livro A sociedade do espetáculo, de Guy Debord, é a de que a sociedade consumidora do capitalismo e as nações soviéticas do pós-guerra se constituem em um espetáculo de mistificação onde o público seria forçado a ser o espectador passivo (DOWNING, 2007, p.98). Em outras palavras, imagina-se que a experiência real - que implica numa participação - estaria confiscada em função de uma vivência mediada por terceiros. Debord fala da "irrealidade da sociedade real": 
"Considerado em sua totalidade, o espetáculo é ao mesmo tempo o resultado e o projeto do modo de produção existente. Não é um suplemento do mundo real, uma decoração que the é acrescentada. É o âmago do irrealismo da sociedade real. Sob todas as suas formas particulares - informação ou propaganda, publicidade ou consumo direto de divertimentos -, o espetáculo constitui o modelo atual da vida dominante na sociedade. É a afirmação onipresente da escolha já feita na produção, e o consumo que decorre desta escolha. Forma e o conteúdo do espetáculo são, de modo idêntico, a justificativa total das condições e dos fins do sistema existente" (DEBORD, 1997, p.14).

Nos anos imediatamente anteriores à Internacional Situacionista o movimento letrista começa a ensaiar uma teoria baseada na prática do errante urbano. É em 1953 que o termo deriva surge no texto de Ivan Chtcheglov: Formulário para um novo Urbanismo. No entanto é entre os textos Introdução a uma Crítica da Geografia Urbana (1955) e Teoria da Deriva (1956) de Guy Debord, que a deambulação surrealista e as cidades inconscientes são deslocadas pelo ponto de vista da deriva e da psicogeografia:

"Ao contrário do que ocorre nos passeios surrealistas, na deriva o aspecto aleatório é menos determinante do que se possa crer: do ponto de vista da deriva, existe um relevo psicogeográfico da cidade, com corrente contínuas, pontos fixos e vórtices que tornam difícil o acesso a certas zonas ou a saída das mesmas" (DEBORD, 1956).

A princípio, a deriva se constitui com grupos de duas ou três pessoas, unidas por um mesmo estado de consciência. Visto que a confrontação das impressões entre os distintos grupos deve permitir chegar a conclusões objetivas, sua duração pode ser de um dia ou meses. Os situacionistas contestam a cidade inconsciente e onírica dos surrealistas através da cidade espontânea e lúdica, substituindo o acaso por algumas "regras" que devem ser rompidas ao longo do percurso liberando a atividade criativa das constrições socioculturais, projetando ações estéticas e revolucionárias dirigidas contra o controle social (CARERI, 2009, p. 102).

As intervenções situacionistas ocorriam em meio ao "espetáculo da vida cotidiana" em ações, denominadas détournement - ou desvio - que se realizavam sob a forma de um rearranjo de formas visuais oficiais e estabelecidas, pervertendo o uso original ou subvertendo suas funções. A estratégia do desvio, em grande parte dos casos, tem proximidade com o conceito de Ready-made do dadaísta Duchamp, mais exatamente ao que pode ser chamado de um Ready-made retificado, com a própria idéia de apropriação.

A arte contemporânea a partir da década de 60 estabelece uma nova relação com a paisagem, que busca ultrapassar as relações de significação presentes nas obras 
modernistas da primeira metade do século XX. Mais do que negar os regimes de visibilidade e circulação das obras, busca-se um movimento em relação ao "fora" da arte a uma exterioridade que a conecta com o cotidiano, o espaço do cotidiano ou o espaço 'vivido' fora das galerias e do circuito do mercado de arte e confere ao espectador a condição de participante e transformador da obra. A própria obra se abre para as relações de significação produzidas como acontecimento in situ.

Datam desta época um grande número de novas expressões em relação à especificidade que a obra assume com seu entorno: Land Art, Environmental Art, Outdoor Art, Happenings, Performances, etc. Em relação à paisagem tanto os Earthworks nos Eua quanto a Land Art na Europa traçam uma relação direta com o conceito de paisagem. Em a Idéia de Natureza na Arte Contemporânea, Colete Garraud coloca que a denominação Land Art é considerada como mais estritamente europeia, mas tomada em seu sentido mais amplo, pode de fato reunir artistas americanos e europeus se o trabalho atender à duas condições: a primeira é que o artista deixa 0 atelier para intervir no meio natural, in situ; a segunda, é que ele deixa sua marca no lugar sem pré-julgar o modo de acesso do espectador à obra, direta ou mediada pela fotografia, o filme, o mapa, o desenho ou o texto.

Segundo Colete Garraud (1994) há ainda uma relação muito forte com o tempo e a efemeridade da obra: o desaparecimento determina a incorporação de novos meios e técnicas no regime de visibilidade da obra, tais como a fotografia, os croquis, os mapas, que adquirem o estatuto da obra, como permanência de seu processo.

A fotografia na Land Art quando registra um trabalho não visível, efêmero ou remoto adquire o estatuto da obra, rompe com o simples registro e se torna o campo de articulação entre escultura, o corpo, a paisagem e sua própria imagem. Os campos de sentido da fotografia revelam tanto uma abordagem direta quanto um olhar dialético em relação ao 'sítio' da obra.

Aqui a escultura é abordada em seu sentido ampliado e relacional em contato com o meio em natural. Não se trata puramente de um retorno à natureza, já que essa relação na arte sempre existiu, mas as práticas out-doors que transformam a relação com o meio em que se inserem e rompem com as estruturas de representação e circulação de obras dominantes na arte.

A pintura de paisagem cede lugar à escultura e a escultura se abre para o ambiente não mais como mimesis ou representação, mas como artifício e produção de novos 
significados em relação à natureza. A paisagem é abordada de forma relacional e não mais como suporte ou objeto de contemplação e representação, mas como meio pelo qual se estabelecem as significações na obra de arte, em constante diálogo.

Para Jean Paul Brun a Land Art promoveu:

"(...)uma das maiores rupturas operadas nas práticas de criação (colocando em questão, o atelier, a escala das obras, a acessibilidade aos sítios, o andamento da gestão do projeto, criação de equipes de trabalhos para as obras em ação) exercitam, rupturas nas práticas de exposição e de comercialização, colocando em questão o lugar de exposição, galeria ou museu. As obras são inamovíveis e situadas em lugares de difícil acesso, algumas são efêmeras. A ruptura produz efeitos nas práticas de aquisição e de coleção: o que se compra, o que se coleciona, como se expõe? Nas práticas de legitimação: o que se critica e como? Necessidade de fazer a viagem, de repensar sua concepção de obra de arte, seu modo de descrever e de escrever sobre a arte." (BRUN, 2006. p. 185, tradução nossa)

Carl Andre, por exemplo, não considera mais a escultura como um objeto autônomo mas considera o conjunto "forma-escultura-lugar" integrando com espaço em que se encontra. Para ele, o espaço intervém na forma última da obra e a forma, como paisagem, participa da intervenção in situ.

As intervenções in situ apresenta ainda relações estreitas com arte conceitual e o minimalismo que se ampliam também na década de 60. Há uma continuidade, nas primeira intervenções minimalistas in situ, que ultrapassa o formalismo das construções geométricas simples e repetidas, recusando qualquer relação de ordem privada, intimista e subjetiva entre espectador e obra. Estas obras aumentam o espaço em seu torno, já inscrito em um movimento de expansão e dilatação.

Quanto ao corpo que participa da obra, há a relação fenomenológica ao percorrê-la e participar de sua composição, há uma metamorfose ao se percorrer o espaço e ser invadido por ele, aqui se dá um deslocamento importante na apreensão da paisagem já que ao percorrê-la, perde-se o referencial objetivo e entramos no campo da percepção fenomenológica e o corpo dos participantes é posto, por vezes, no centro deste processo, como matriz sensória e significante da obra. Penone diz, não é o homem que é cego, é o caminho que escapa: "A clareza do caminho bem marcado é estéril, encontrar o caminho, navegar e sondar as Silvas, é a escultura. O caminhar é o instrumento da metamorfose, para o homem que se confunde com a natureza." (PENONE apud. GARRAUD, 1994).

Tanto a obra quanto o participante estabelecem uma relação que rompe com a 
distinção sujeito e objeto de arte. $\mathrm{O}$ sujeito não percebe mais a obra com um "olharsem-corpo" sublime e idealizado, pois o acontecimento ou o objeto de arte é experimentado aqui-agora pela presença do corpo que percorre as materialidade das paisagens naturais ou no impuro e ordinário espaço do cotidiano (KWON, 1997). Quando Robert Smithson descreve os Monumentos de Passaic em 67, se refere a uma experiência do corpo que percorre as paisagens cotidianas de um bairro degradado, e estabelece ao percorrê-lo, relações dialéticas de significação temporal com a paisagem degradada: "Esse panorama zero parecia conter ruínas as avessas, isto é, todas as novas edificações que eventualmente ainda seriam construídas. Trata-se do oposto da 'ruína romântica’ porque as edificações (...) se erguem em ruínas antes mesmo de serem construídas." (SMITHSON, 1967, p.165).

Artistas como Robert Smithson, concebiam o lugar nas obras de site-specific não só em termos físicos e espaciais, mas como uma estrutura cultural definida pela experiência sígnica corporal. E a presença, não mais como um corpo neutro ou genérico, mas como matriz sensória, objetiva e subjetiva, marcada por classe, raça, gênero, sexualidade. A saída do atelier para o espaço da cidade ou da natureza e a inserção do corpo, como participante dessa experiência, era e é, antes de tudo, política.

E embora as obras com mídias locativas sejam em parte, devedoras da questões levantadas pelas obras site-specifc, sobretudo no que diz respeito à representação cartográfica do percurso (TEUTERS E VARNELIS, 2006), é a partir da estética relacional que esses agenciamentos buscam uma experimentação mediada das relações humanas no espaço: uma produção cultural do lugar, resultado da mediação, da mobilidade e da locatividade.

Para Nicolas Bourriaud (2009) a arte contemporânea se inscreve como projeto de reificação da modernidade, para a qual as teorias relativistas pós-modernas não dão conta de inserir na história a multiplicidade das culturas periféricas não-ocidentais, que enfrentam a homogeinização e a padronização de multiplicidades que se inscrevem fora da centralidade da cultura contemporânea ocidental. O modernismo, máquina industrial colonizadora (Bourriaud, 2009) é intensificado pela globalização no contexto pósmoderno e o multiculturalismo contemporâneo, se torna uma ferramenta tão ou mais potente para delimitar as fronteiras do fazer artístico ocidental: "que relega os artistas não ocidentais, até então alijados, ao papel de convidados da cena cultural, negandoIhes qualquer tipo de juízo, rotulando-os por sua condição, status ou origem, de maneira 
tão taxativa ou excludente quanto a própria negação desses sujeitos." (MONTEIRO, A. 2012$, p. 2$)^{44}$

Dessa forma para Bourriaud o que o pós-modernismo chama de hibridização de multiplicidades, consiste em injetar no tronco de uma cultura popular, previamente uniformizada, algumas "especificidades" muitas vezes caricaturais. (BOURRIAUD, N. 2009. p.20). Dessa forma a diversidade "elevada a categoria de pensamento" permite opor-se a uma raiz (radical), implantada pelos manifestos estéticos-políticos ao longo do século XX, estruturados sobre a arborescência da universalidade modernista.

Vale lembrar que a analogia entre rizoma e radicante demonstra a oposição entre o termo "radical" relacionado a arte de vanguarda. "Radicante" é a planta que possui várias raízes ou a que é capaz de produzi-las sempre que replantada; Assim Borriaud promove uma aproximação conceitual com a filosofia da diferença, para lançar as bases de Radicante:

\begin{abstract}
"O rizoma se apresenta como um emaranhado de relações, que aponta e se alastra em todas as direções ao mesmo tempo, e no qual cada nó pode ligar-se a qualquer outro; um rizoma não pressupõe uma diferenciação entre sujeito e objeto (o princípio da ontologia simétrica) e não apresenta começo nem fim, abolindo, portanto, a direção e o sentido do próprio tempo, que, por conseqüência, não se apresenta mais como uma sucessão de passado, presente e futuro: "Um rizoma não tem começo nem fim; está sempre no meio, entre as coisas, é um inter-ser, um intermezzo" (DELEUZE e GUATARRI, 2004, p. 27).
\end{abstract}

Nesse sentido a criação radicante, termo que designa um organismo que faz crescer suas raízes a medida que avança (BORRIAUD, 2009, p. 22), indica as bases de uma estética heterogênea, múltipla, capaz de estabelecer intercâmbios, descodificar imagens, desterritorializar e reterritorializar (DELEUZE, 2004) o fazer estético a partir de sua localidade: 0 radicante se desenvolve contextualmente, se confronta ao solo que encontra e "se traduz nos termos do espaço em que se move" (BOURRIAUD, 2009, p.50).

Abordando obras que privilegiam a noção de impermanência, Bourriaud aponta os cruzamentos entre espaço e tempo: time-specific, em resposta à arte site-specific, como uma forma de considerar as singularidades que atravessam a arte relacional, para além da materialidade dos lugares, incorporando os fluxos temporais que adquirem status predominante na fase atual do capitalismo avançado.

\footnotetext{
${ }^{44}$ MONTEIRO, A. Radicante: por um estética da globalização: nota de leitura. Revista-Valise, Porto Alegre, v. 2, n. 3, ano
} 2, julho de 2012. 
Para Borriaud, os artistas radicantes promovem um deslocamento da forma como a arte de vanguarda pretendia "transformar o mundo" a partir de uma linguagem revolucionária. Assim para ele arte contemporânea questiona justamente a ideia de "sintaxe da forma artística" que vigorou no período das vanguardas, pois "não se trataria mais de gerar sentido através de signos representados, mas de produzir relações com o mundo" (BOURRIAUD, 2011a, p.157). Para o autor os Radicantes praticam um realismo operatório, que tem no cotidiano seu meio de ação e transformação. Não se trata mais de expressar e (re)estruturar signos, mas de mas articular o nomadismo a partir da "navegação sinuosa pela constelação de signos" do cotidiano.

Segundo André Lemos dimensões da mobilidade e do nomadismo nas metrópoles contemporâneas, ocupam um lugar central para sua compreensão. O capital tende a materializar-se através da informação, o fluxo de signos é o que caracteriza seu exponencial crescimento (VARGAS, 2012. p.60) ${ }^{45}$. André Lemos em seu artigo As Dimensões da Mobilidade (2009) aponta ainda a interconexão das dimensões da mobilidade: física, temporal, informacional e do pensamento. Dimensões que se afetam mutuamente e expandem ou contraem a extensão, o acesso e a velocidade de consumo, lugares, informações e conhecimento. Nesta perspectiva, a mobilidade, como produto social, é também política:

"No entanto, a mobilidade deve ser politizada. Ela não deve ser vista apenas como o percurso entre pontos, ou o acesso a determinada informação. Ela não é neutra e revela formas de poder, controle, monitoramento e vigilância, devendo ser lida como potência e performance." (LEMOS, A. 2009. p. 29)

A tecnologia então é pensada no interior de um contexto social, gerando ou intermediando relações. Esse percurso é possível a partir das proposições da estética relacional e posteriormente de Radicante, tratadas por Nicolas Bourriaud como um campo prático capaz de compreender a crescente complexidade das obras de arte em função das relações humanas que são figuradas em sua base.

Segundo Bourriaud, a modernidade contemporânea instaurou novas circunstâncias sociais, tão significativas, que protagonizam de um tipo de produção cada vez mais recorrente a partir dos anos 90 do século XX:

"Essa produção é observada através do critério de coexistência em que toda obra de arte cria um modelo de sua própria sociedade, seja transpondo o âmbito do real ou se traduzindo nele. 0 critério de coexistência é o ponto de partida para a Estética Relacional, que é uma

\footnotetext{
${ }^{45}$ VARGAS, José Dario Vargas. Branding na sociedade do Espetáculo. Dissertação. São Paulo: Eca-Usp, 2012.
} 
teoria baseada na análise de obras de arte em função das relações humanas que figuram, produzem ou suscitam. A Estética Relacional aponta para o diálogo que se funda no elemento social. " (NUNES, apud. BORRIAUD, 2007, p.62).

Embora haja aproximações entre as obras com mídias locativas e a estética relacional, principalmente aquela atribuída aos artistas Radicantes por Nicolas Borriaud, para Tuters e Varnelis (2006) os projetos com mídias locativas podem ser categorizados de acordo com um dos dois tipos de mapeamento: marcação ou anotação que, segundo eles, correspondem a dois pólos arquetípicos de seu caminho através da arte: a arte do final do século 20 e a fenomenologia crítica e talvez, ainda que de forma figurada, com as práticas situacionistas do détournement e da deriva e da psicogeografia.

Nesse contexto, o principal deslocamento que as mídias locativas promovem é a mediação de toda a experimentação da mobilidade no espaço e na produção coletiva do lugar. Esta convergência entre as mídias móveis que se acoplam a um corpo nômade, que por sua vez percorre, demarca e mapeia informacionalmente os lugares implica na revisão fenomenológicas de apreensão do espaço; na revisão da deriva situacionista e sua psicogeografia. Cada uma dessas experiências se desenvolve em um meio tecnocientífico-informacional completamente diferente que afetam tanto o tempo como a experimentação desses lugares.

\subsection{2.a - Agenciamentos Móveis e Locativos}

As possibilidades que se abrem para as investigações no campo da percepção estética mediada, quanto para a produção de agenciamentos relacionais e lugares específicos a partir da convergência midiática são imensas. Cada obra neste mapeamento cria um contexto e espacial e midiático específico, que atua diretamente nas singularidades de expressões que meios os cíbridos podem adquirir in situ, revertendo o uso original de cada mídia.

Dessa forma as questões em torno da deriva mediada do grupo Blast Theory, se diferencia em muito daquelas que os imigrantes sofrem ao atravessar a fronteira do México com os EUA, na obra Transborder Immigrant Tool, embora ambas tratem a mobilidade possibilitada pelo "andar conectado em rede". 
Quando Wodiczko propõe ampliar a voz e a visibilidade de adolescentes em situação de abuso ou silenciamento no Japão ele o faz de forma completamente diferente da conexão em rede que a obra Magafone.net utiliza para ampliar a voz e a visibilidade de grupos excluídos ao redor do mundo.

A seguir apontamos algumas questões específicas que giram em torno da arte feita com mídias locativas. Sem pretender esgotar o campo de complexidade de cada obra, identificamos em cada uma as questões que se atém ao campo da mobilidade e locatividade em cada obra:

\subsection{2.b - Cartografias e mobilidade em espaços cíbridos}

\section{CYSMN? | Blast Theory}

O Blast Theory é um dos primeiros coletivos a desenvolver métodos de relação entre o espaço físico e o virtual desde a década de 90. Na época de elaboração do jogo CYSMN? não havia a disseminação de sinais GPS acoplados aos dispositivos móveis, nem mesmo a disponibilidade de mapeamentos tais como o Google Maps ${ }^{46}$. 0 jogo interligou uma série de aplicações que seriam amplamente reunidas e difundidas somente mais tarde com os Smartphones: mapeamentos, realidade aumentada, geolocalização, transmissão de dados via streaming, etc.

$\mathrm{Na}$ época de desenvolvimento do jogo (2002), havia uma espécie de guerrilha territorial invisível pela implantação de sinais privados de Wi-Fi ${ }^{47}$ (BUCKER-COHEN, 2009, p.11), que estavam sendo implantados no espaço público, competindo entre si e muitas vezes anulando os sinais gratuitos ou mais fracos. Essa disputa invisível pela ocupação de territórios públicos, ainda que não seja a temática central do jogo, é um dos determinantes que os fez desenvolver servidores e antenas de transmissão próprios, visto que, os territórios urbanos hoje amplamente ocupados por sinais wi-fi, possuíam na época grandes áreas sem acesso.

\footnotetext{
${ }^{46}$ Google Maps disponível em: https://www.google.com.br/maps. Acesso em: 19/10/2015.

${ }^{47}$ Para mais informações sobre o tema, pesquisar o caso de implatação de sinais Wi-Fi pela Starbucks. Disponível em BEIGUELMAN, G. (et.al.) (Org.). Apropriações do (In)comum: Espaço público e Privado em Tempos de mobilidade. São Paulo: Instituto Sérgio Motta, 2009. p.10-15.
} 
Uma das questões que se coloca em torno da hiperlocatividade ${ }^{48}$ (BEIGUELMAN, 2012) que é fomentada pela difusão dos dispositivos móveis com GPS e pelo mapeamento e localização e rastreamento em rede, é a objetivação com que se representam os dados espaciais em um mapa de dimensões cartesianas, a despeito de décadas de desconstrução desse espaço na arte e na arquitetura.

Para a midiartista e professora Giselle Beiguelman o uso massivo dos mapas associados a uma abordagem unidimensional associada à lógica do tagueamento (demarcar um ponto no espaço relacionando-o um lugar, a uma pessoa ou a um grupo ou uma imagem) disseminada pelos check-ins nas redes sociais, desvincula os mapas de seu caráter diagramático no sentido que Deleuze $(1988,44)$ dá ao conceito:

'O diagrama não é mais o arquivo, auditivo ou visual, é o mapa, a cartografia, co-extensiva a todo campo social. É uma máquina abstrata. Definindo-se por meio de funções e matérias informes, ele ignora toda distinção de forma entre um conteúdo e uma expressão, entre uma formação discursiva e uma forma, entre uma conteúdo e uma expressão, entre uma formação discursiva e uma formação nãodiscursiva. É uma máquina quase muda e cega, embora seja ela que faça ver e falar." (DELEUZE apud. BEIGUELMAN, 2012, p. 3)

Entretanto em favor da obra é possível argumentar, que a participação mediada através do mapa esquemático não ofusca ou diminui a apreensão sensível e direta da paisagem urbana. O mapa aciona a representação numérica de dados espaciais e 'aumenta', sem substituir, a percepção direta da paisagem urbana, que a despeito do mapa, é experimentada e transformada diretamente, com a participação ativa de cada jogador. O próprio grupo Blast Theory define como os elementos mais importantes dessa obra, as noções de orquestração e jogabilidade, ou seja, traz para o interior da obra a preocupação de como se movimentam as relações humanas, tornando-o um exemplo tático de obra que adota a estética relacional como meio de se apropriar de forma tática e agenciar as relações em rede.

A apropriação das formas dominantes de representação, tais como os mapeamentos do Google, é entretanto necessária para desconstruir um monopólio, ou uma única forma de representação de mundo. A pluralidade de apropriações e transformações deste meio é o que determina a desconstrução de uma forma de representação, uma

\footnotetext{
${ }^{48}$ a hiperlocatividade decorre da prática massificada de demarcar uma localização espacial em rede, como por exemplo, os mapeamentos do Google Maps ou as formas de rastreamento e rastreamento e localização dos usuários de uma rede via GPS;
} 
verdadeira guerrilha de (des)territorializações do discurso cartográfico, em seu sentido diagramático.

\subsection{2.c - Práticas de desterritorialização da Vigilância e do Controle}

\section{ZAPPED!|Preemptive Media}

Os artistas do Preemptive Media - Beatriz da Costa, Jamie Schulte e Brooke Singer - se preocupam com a questão da vigilância e o uso de tecnologias de monitoramento, como práticas passíveis de serem utilizadas com finalidades de lucro. 0 grupo torna visível os elementos de uma nova "ecologia de consumo" mediada por invasões constantes de privacidade. Seus trabalhos partem da idéia de que a vigilância concreta não está somente nas câmeras espalhadas pelo espaço urbano, mas também em uma série de instrumentos corriqueiros e invisíveis instalados em supermercados e lojas de todos os segmentos.

O trabalho Zapped! insere-se na discussão da implementação maciça e crescente da tecnologia de etiquetas de identificação por rádio-frequência (Radio Frequency Identification, ou RFID). Nos países industrializados, o uso de RFID tem sido gradativamente empregado, pois permite a localização de objetos, animais ou pessoas, podendo ser utilizado tanto no controle de crianças ou prisioneiros, como no rastreamento de produtos comercializados.

Por meio de propostas participativas de produção de equipamentos que sensibilizem para a crescente demanda de sistemas de controle, o grupo desenvolve workshops de confecção de dispositivos para confundir os sinais de Rfid como a Barata de Madagascar e de sensibilização dos participantes para a pervasividade desta tecnologia.

Neste projeto, as mídias locativas oferecem o suporte conceitual, para examinar as estruturas tecnológicas e seus impactos sociais. Esta ação tensiona criticamente a pervasividade promovida pela infraestrutura de implantação do RFID.

Segundo Tuters e Varnelis (2006) as mídias locativas se esforçam para atingir um público de massa e envolver tecnologias de consumo, redirecionando seu poder. 
De acordo com a União Internacional de Telecomunicações (UIT) ${ }^{49}$, estamos entrando em uma sociedade de objetos conectados em rede e logo os objetos serão os usuários mais comuns da Internet, comunicando dados uns aos outros.

Segundo Bruno Latour, estes objetos conectados ou a Internet das Coisas, devem ser um foco do nosso tempo, especialmente para os artistas:

"Coisas são conjuntos controversos de problemas emaranhados, e não simplesmente objetos postos à parte de nossas paixões políticas. Os envolvimentos das coisas e da política envolve ativistas, artistas, políticos e intelectuais. Para montar este parlamento, a retórica não é suficiente nem eloquente; Isto requer o uso de todas as tecnologias, especialmente da tecnologia da informação e a possibilidade para as artes 're(a)-presentarem' quais são os pontos comuns". (LATOUR apud. VARNELIS e TUTERS, 2006, p. 359, tradução nossa)

\subsection{2.d - Práticas de compartilhamento (sound-specific):}

\section{TATICAL SOUND GARDEN | Mark Shepard}

Das múltiplas camadas de relações que esta obra estabelece com a percepção estética do espaço público urbano, destacamos para o contexto desta pesquisa, dois eixos que se cruzam com a análise da mobilidade quanto da descentralização de dados. Esta obra se insere em um pensamento crescente de produção de uma cidade participativa e descentralizada dos meios de produção e partilha dominantes, que envolve tanto a busca por novas formas de articular e negociar a propriedade intelectual do que é produzido e compartilhado em rede.

Esta obra envolve tanto o estabelecimento de paisagens sonoras nas cidade ampliando a percepção fenomenológica do espaço, quanto uma abertura do compartilhamento a partir do espaço urbano.

Zonas de vizinhança sonoras, que não se limitam apenas a trocas de música, mas de gravações locais, ruídos, sons, conversas. Abrindo a obra para um verdadeira ecologia sonora, compartilhável nas cidades.

Segundo Mark Shepard um dos objetivos dos jardins sonoros é a ampliação perceptiva da esfera sonora do espaço urbano. Se nossa cultura estética é fortemente fundada sobre a formulação teórica da percepção visual do espaço urbano, "a cultura sonora da cidade é considerada apenas de maneira elíptica" (BAMBOZZI, 2010. p.203)

\footnotetext{
${ }^{49}$ Disponivel em: http://www.tu.int/en/Pages/default.aspx. Acesso em: 26/09/2015.
} 
mas ao mesmo tempo temos uma riquíssima fonte de recursos sonoros e mesmo que as cidades sejam percebidas como disruptivas e barulhentas, temos "práticas cotidianas comuns por meio das quais os espaços sônicos das cidades são ocupados e negociados" (BAMBOZZI, 2010. p.203). Assim o primeiro objetivo delineável desta prática artística seria o hackeamento sonoro dos meios urbanos. A percepção sonora é bem menos tangível que a percepção visual dos objetos, no entanto o som tem uma propriedade muito mais pervasiva que o campo de visão. Para Mark Shepard o som difere da percepção visual no sentido em que a relação sujeito e objeto, não pode ser distanciada, demarcada. Para não ver, basta fechar os olhos ou desviar o olhar, para não ouvir devemos acoplar próteses (fones de ouvido) que equalizam nossa percepção sonora do espaço circundante.

Mark Shepard, aponta em seus agenciamentos para um urbanismo propagativo, mídias táticas "parasitárias" que negociem constantemente a apropriação de tecnologias das grandes empresas para promover a ruptura entre formas de consumo e compartilhamento destas tecnologias. Nesse sentido TSG (Tatical Sound Garden) promove uma rede de compartilhamentos locais, associados a zonas com wi-fi livre, descentralizada das grandes políticas de proteção as propriedade intelectual e patentes que envolvem o compartilhamento de $m p 3$ na internet.

\subsection{2.e - Mapeamentos Colaborativos}

\section{Transborder Immigrant Tool | Electronic Disturbance Theater}

O Transborder Immigrant Tool fornece uma nova perspectiva para a demarcação geológica virtual e permite que os segmentos da sociedade global excluídos desta rede emergente de hiperlocatividade, obtivessem acesso rápido e simples ao sistema de GPS. Para além do acesso, o Transborder Immigrant Tool acrescenta um algoritmo capaz de traçar as melhores rotas e trilhas, dias e horas para os imigrantes para atravessarem o deserto da forma mais segura possível.

Segundo Dominguez e Staulbaum (2010) as tecnologias de georreferenciamento e demarcação, tais como as mídias locativas, permitiram um relacionamento inteiramente novo com a paisagem na forma de aplicativos para simulação, vigilância, locação de recursos e gerenciamento de redes cooperativas e de padrões pré-deslocamento, onde 
se programa um algoritmo que prevê as potenciais rotas que um usuário pode seguir, bem como a melhor hora e o melhor dias para atravessar a fronteira.

Carolyn Guertin analisa a chamada terceira geração de mídia ativistas após a Net.art e as Mídias Táticas: os artistas locativos. Segundo ela, em seu texto em seu texto "Mobile Bodies, Zones of Attention, and Tactical Media Interventions", a obra Transborder Immigrant Tool possibilita o agenciamento humano em meio a uma zona real de conflito, capaz de estabelecer um confronto mais contundente em relação a integração do corpo, do espaço e das mídias. Para Carolyn, essa obra ultrapassa a questão das mídias como formas de "extensões ampliadas dos olhos ou dos ouvidos", onde um novo tipo de ativismo emerge, envolvendo a concretização da mobilidade e da locatividade ao permitir que os usuários se relacionem com as histórias de um lugar, em vez de reduzir os lugares a um cálculo "desencarnado" em um mapa.

\subsection{2.f - Estética relacional em redes cíbridas}

\section{MEGAFONE.NET | Antoni Abad}

Ao articular grupos diversos, em pontos distantes do planeta, o Megafone.net amplia a voz e a visibilidade dos grupos envolvidos. Ampliando e relacionando a contextos locais e distantes, uma série de olhares para o cotidiano, para o trânsito das cidades, acontecimentos internos ou externos aos grupos, revelando formas sensíveis de percepções deste cotidiano e da necessidade de compartilhar experiências pessoais ou em grupo. Estes agenciamentos promoveram uma grande diversidade de experiências e trocas locais amplificadas no contexto global.

A arquitetura da informação do Megafone.net, organiza bancos de dados que retratam a experiência urbana sob a perspectiva de cada coletivo. Ela faz a mediação dos processos discursivos em espaços urbanos variados e possibilita o compartilhamento público e online de representações de experiências territoriais que são recontextualizadas e ressignificadas na rede. Para Alzamora e Carvalho (2010) a cidade é tomada como instância discursiva e mediada pelos dispositivos comunicacionais contemporâneos, os quais estabelecem vínculos por meio de relatos multimidiáticos e hipertextuais fundamentados na vivência cotidiana. A imagem, captada via celular, mais que o texto escrito que normalmente a acompanha, torna-se, 
nesse caso, o principal elemento aglutinador através do qual o cotidiano é registrado e compartilhado em tempo real.

"Se, por um lado, cada cidade representada na rede Megafone.net pode ser considerada uma forma mediadora da experiência urbana contemporânea, por outro, a programação da rede Megafone.net funciona como uma espécie de segunda camada de mediação, a qual delineia as possibilidades de registros da experiência cotidiana em cada coletivo do projeto, assim como as interações que ocorrem em torno desses registros. A interseção entre as dimensões urbana e tecnológica da mediação conforma, na rede Megafone.net, zonas diferenciadas de poder, fundadas na capacidade de gerar conexões em torno de processos de auto-representação." (ALZAMORA, G. e CARVALHO, 2010. p.68) 


\section{CAPÍTULO III}

\section{Planos de consistência e linhas de força}

"A essência da tecnologia é a guerra."

Paul Virilio

\section{1- Agenciamentos do Espaço Cíbrido: Mobilidade e Locatividade}

O termo Mídias Locativas, foi cunhado por Karlis Kalnins, como título para um workshop organizado no Centro para a Cultura da Novas Mídias - RIXC em 2002, em uma cidade militar abandonada, situada na costa báltica da Letônia (GALLOWAY, 2005). O objetivo do workshop era identificar e criar, dentro da lógica Do-it-Yourself (DIY), receptores baratos para Satélites de Posicionamento Global (GPS), que permitissem obter os meios de produzir informações cartográficas com precisão militar. A partir deste evento, o termo foi adotado por artistas como forma de diferenciar a finalidade de uso aplicada às artes, daquelas desenvolvidas por militares, para fins de vigilância e controle.

Para Paul Virilio, não se pode compreender a evolução tecnológica, sem se compreender a evolução das estratégias militares. De fato, os sistemas de georreferenciamento, rastreamento e localização em tempo real foram criados em projetos militares como resultado direto da corrida armamentícia, que inicialmente, fomentou a corrida espacial entre a União Soviética (URSS) e Estados Unidos (EUA) no pós-guerra. (BORGES, 2013, p.28)

Atualmente, os Serviços Baseados em Localização, ou simplesmente LBS ${ }^{51}$, são parte de praticamente todos os sistemas políticos que operam por bases computacionais de controle. Eles evoluíram de simples programas de sincronização de dados, para ferramentas de autenticação de dados implementadas em Serviços Baseados em Localização. Os LBS's são tecnologias capazes de obter dados específicos com base no referente local e temporal, ou então fornecer chaves criptográficas e sistemas de garantia de integridade de dados, baseados em localização. As Mídias Locativas se referem portanto ao conjunto de tecnologias de telecomunicação, que interligam os

\footnotetext{
${ }^{50}$ RIXC: Center for New Media Culture. Disponível em: http://rixc.org. Consutado em: 11/11/2015;

${ }^{51}$ Os LBS e LBTs são softwares associados a satélites e sistemas de monitoramento espacial que incluem controles específicos para a localização em tempo real de dados móveis. Mais informações sobre estes sistemas disponíveis em: http://ufpr.dl.sourceforge.net/project/jumppilot/w other freegis documents/articles/Lbs lecturenotes steinigeretal2006.pdf Acessado em 11/11/2015.
} 
processos de transmissão e recepção de dados a um local e promovem a associação entre espaço físico e informacional.

No início deste século, com a difusão em massa dos Smartphones, os mais variados tipos de tecnologias foram associados a estes aparelhos: os Sistemas de Posicionamento Global GPS, ${ }^{52}$ Bluetooth, o acesso à internet e às redes sem fio (Wi-fi, Conexão $3 G$ e 4G), os leitores de Qr-codes, aplicativos de leitura de realidade aumentada, mapas, etc. Com estas tecnologias houve a reconfiguração sem precedentes, nas formas de se conectar em rede, de acessar e de produzir informações, de perceber o espaço mediado e mapeá-lo ou demarcá-lo com camadas informacionais.

Os smartphones, estes minicomputadores portáteis, conferiram mobilidade à forma como nos conectamos e como capturamos as imagens, sons, vídeos e textos do cotidiano e os inscrevemos em rede. A mobilidade conectada se tornou um componente difuso da percepção, produção e partilha do cotidiano.

Como vimos, a fase da Internet 1.0 promoveu o upload de informações para o ciberespaço e as mídias locativas vêm promovendo o download dessas informações nos objetos, edifícios no espaço urbano e no corpo. Dessa forma, os conceitos de espaço pós-virtual (BEIGUELMAN, 2011), de territórios informacionais (LEMOS, 2008) ou espaços de fluxos (CASTELLS, 2000), surgem como conceitos voltados para a complexidade desse processos de hibridização, que é sobretudo estético e político.

Peter Anders (2001), assim como Vilém Flüsser , adota uma abordagem materialista, ao considerar o espaço virtual como um continuum do espaço físico, composto pela materialidade própria aos impulsos magnéticos e, por ser um fenômeno relativamente novo, não foi totalmente capturado por relações de força ou definições muito rígidas. Fazendo parte de uma espaço liso prestes a se estriar.

Tuters e Varnelis (2006) apontam para o fato de que as mídias locativas surgiram no campo da arte, na primeira década do século XXI, como resposta à experiência da "descorporalização" que a Net Art promovia, ao utilizar como interface a tela do computador. Nesse sentido os sistemas de georreferenciamento e as interfaces móveis, permitiram o

\footnotetext{
${ }^{52} 0$ sistema de posicionamento global (GPS) foi autorizado pelo Congresso dos Estados Unidos em 1973 e é operado pelo departamento de defesa dos Estados Unidos. Os instrumentos envolvidos nesse sistema são um anel de 24 satélites que circundam a Terra de modo tal que, pelo menos quatro deles, são visíveis de qualquer ponto no globo em qualquer momento. 0 sistema tem sido usado para a navegação de veículos, mas encontrou seu caminho também na internet móvel, quando o grupo de satélites é usado para localizar a posição de um usuário. (SANTAELLA, 2008, p. 100)
} 
deslocamento do espaço informacional da Net.Art para as ruas, transferindo a informação focada no emissor: a superfície significante da "tela do computador" na Net Art, para o espaço dos objetos, dos edifícios e das cidades, agregando a eles camadas informacionais e novos campos de significação.

O Headmap Manifesto escrito em 1999 por Ben Russel ${ }^{53}$, já delineava algumas questões fundamentais abordadas mais tarde pelas mídias locativas:

"Os programas de localização e os dispositivos móveis em rede possibilitam anotações invisíveis ligadas aos espaços, lugares, pessoas e coisas.(...) a localização informativa, permite aderir dados invisíveis a espaços, lugares, pessoas e objetos. 0 espaço real pode ser marcado e demarcado invisivelmente." (RUSSEL, 1999, p.4, tradução nossa).

Foi de Russel também a afirmação inicial de que o ciberespaço estaria "pingando" nas coisas : "the internet has already started leaking into the real world". (RUSSEL, 1999, p.5). Tuters e Varnelis (2006) classificam duas formas correntes nos projetos iniciais de mídias locativas: a anotação e a marcação. Com a anotação, busca-se adicionar dados informacionais ao mundo físico, incorporando assim, o conhecimento social na paisagem da cidade para que os outros as recuperem mais tarde. Com a marcação, geralmente traçam-se mapas a partir de trajetórias individuais ou coletivas, rotas mentais, derivas e percursos cotidianos.

As mídias locativas incorporam a geolocalização e rastreamento, integrando-os ao processo artístico. Dessa forma, muitos projetos, por sua singularidade em relação ao lugar em que se inserem, dependem de pesquisa e desenvolvimento para serem executados e freqüentemente demandam patrocínio ou utilização de equipamentos de empresas de tecnologias. Como muitas são as empresas interessadas em pesquisa e desenvolvimento dessas novas tecnologias, que criam, financiam e apoiam os festivais de arte digital, as principais críticas direcionadas às mídias locativas, vêm do fato de serem facilmente capturadas para fins comerciais. Principalmente por serem meios que se apropriam das tecnologias de vigilância e controle e devem portanto obrigatoriamente enfrentar essas questões ao invés de fundamentá-las, como defende Andreas Broekman (diretor do Festival Transmediale em Berlim);

Geert Lovink ${ }^{54}$ afirma que o movimento transformou o circuito de conferências de

${ }^{53}$ disponível em: http://technoccult.net/wp-content/uploads/library/headmap.pdf Acessado em: 11/11/2015;

${ }^{54}$ Geert Lovink (1959, Amsterdã), é professor da European Graduate School, ativista e teórico da mídia neerlandesa. É Ph.D. pela Universidade de Melbourne, fundador do Institute of Network Cultures e faz parte da Adilkno (Fundação para o Progresso do Conhecimento llegal); 
artes midiáticas em um "espetáculo locativo comercial". No entanto, há projetos em mídias locativas que por sua estrutura conceitual permitam a apropriação crítica das formas de utilização dessas tecnologias redirecionando o seu poder. Como nos mostraram tanto o CYSMN?, Zapped!, Transborder Immigrant Tool ou o Megafone.net. Trata-se de não ignorar os novos meios, mas de travar com eles novas relações para desterritorializá-los, operando corte significantes em torno da vigilância e controle de dados, para que possam ser reterritorializados no campo da arte e da arquitetura.

Embora a incorporação do ciberespaço ao espaço físico, através da internet das coisas, ainda seja considerada por muitos, uma esfera independente do nosso cotidiano, o mundo tecnológico não está, há pelo menos duas décadas, separado do espaço físico. Em um sentido mais estrito, a possibilidade de um meio virtual, demanda a criação de toda infraestrutura telemática: servidores, banco de dados, antenas de transmissão, satélites, cabos submarinos, produção de hardwares e softwares, prospecção, extração e processamento de silício, etc. Nesse sentido, tanto a internet das coisas, como as mídias locativas vêm operar, nesse século, a transição da interface humana (tela, mouse, teclado, etc) para os objetos cotidianos, passando a integrá-los em rede e produzir uma quantidade sem precedente de dados interligados. Tal integração, ocasiona como vimos no campo da arte e da arquitetura, novas práticas culturais, chamadas aqui de cibercultura. Esta, no entanto, não se dá por meio de uma esfera separada, mas é contígua à própria vida, inserida nas práticas cotidianas mais comuns. Manuel Castells (2000) argumenta que a cibercultura é parte integrante da organização material, da infraestutura econômica e política das sociedades, sendo inclusive determinante nessas organizações.

Como vimos anteriormente, com os mapeamentos de arte e arquitetura, a emergência de projetos variados com mídias locativas redefinem as definições de espaço, lugar e também dos próprios objetos. Mas junto com eles nossa condição cultural, social e humana:

"O que a emergente era da mobilidade vem colocando em relevo, antes de tudo, é a necessidade de reavaliação dos prognósticos tanto sobre o desaparecimento da experiência humana, do lugar e das interações sociais em presença, quanto sobre a perda da integridade corporal do humano na intersecção com sistemas cibernéticos computadores, organismos engenheirados biogeneticamente, sistemas espertos, robôs, andróides e ciborgues" (SANTAELLA, 2008, p.98). 
De fato, as mídias locativas vêm se inserindo nas camadas mais improváveis do cotidiano, de um chip de celular à um cartão de crédito, que transmitem à banco de dados específicos, informações de hábitos de consumo, locais freqüentados, poder de compra e relações humanas: com quem e com que freqüência nos comunicamos, ou qual o posicionamento espacial de cada um nessa rede, etc. Tanto quanto a reformulação dos conceitos de espaço e lugar, as coisas interconectadas em rede assumem outro estatuto: o de metadados, que reformula suas definições.

Em 2005 o relatório da União de Telecomunicação Internacional ITU ${ }^{55}$, com o título de "Internet das coisas" previa para a internet das coisas uma futuro muito similar às palavras de Mark Weiser, ex-cientista chefe do Centro de Pesquisa da Xérox em Palo Alto: "as tecnologias mais profundas são aquelas que desaparecem. Elas se entretecem no tecido da vida cotidiana até se tornarem indistinguíveis dela". O documento previa que os computadores irão, gradativamente, se tornar objetos comuns do cotidiano e se tornarão processadores e transmissores de dados em uma rede ubíqua. Fazendo emergir novas práticas tecno-sociais com "o potencial de gerar espaços híbridos e formas de participação pública que reconectam as dimensões materiais do espaço público urbano com as participativas da esfera pública das redes" (SHEPARD apud. SANTAELLA, 2008, p.100).

\title{
3.1.1 - Cultura da mobilidade
}

\begin{abstract}
"A cultura da mobilidade é um conjunto de prática sociais e simbólicas que reestrutura as maneiras de ver e perceber o outro e nós mesmo. Atravessadas por substratos impressos e digitais, fonéticos e não fonéticos, nela se emaranham códigos informativos, de programação e estéticos." (BEIGUELMAN, 2009. p.87)
\end{abstract}

A mobilidade é central para a discussão das mídias locativas. Embora, a primeira vista, pareça paradoxal a associação entre locatividade e mobilidade, André Lemos nos lembra que des-locar é sempre atravessar lugares, sejam eles físicos, informacionais ou conceituais.

O termo mobilidade (do lat. mobilitate) designa a propriedade ou qualidade daquilo que é móvel, ou, em seu sentido figurado, facilidade com que se passa de um estado a outro, inconstância, volubilidade ou ainda a facilidade para modificar-se ou variar.

${ }^{55}$ ITU - União de Telecomunicacação Internacional. Disponivel em: http://www.tu.int/en/Pages/default.aspx. Consultado em 12/11/2015. 
(FERREIRA, 1999). Esta definição, embora genérica e arraigada ao senso comum, não dá conta da emergência de um fenômeno, econômico, político e cultural, que atravessa toda a produção do espaço informacional nas últimas décadas. De fato, conforme as técnicas que promovem a mobilidade se alteram, o próprio conceito e as formas de praticá-lo também se modificam. O Futurismo, por exemplo: uma proposição estética sobre a velocidade nas metrópoles no século XX. Os mais variados pesquisadores têm se debruçado sobre a elaboração dessas novas significações que o termo mobilidade incorpora.

A autora Adriana Sousa e Silva (2006) define a mobilidade como os espaços sociais conectados, que se formam a partir do uso de interfaces portáteis. Nesse sentido a mobilidade é resultado das práticas sociais sobre o espaço cíbrido em interconexão com as mídias móveis.

Para André Lemos (2009) a mobilidade informacional e a mobilidade física, transformam e agregam aos espaços outras dimensões físicas, simbólicas, econômicas, políticas, aliadas a bancos de dados eletrônicos, dispositivos e sensores sem fio, portáteis e eletrônicos, ativados a partir da localização e da movimentação do usuário. Esta nova territorialidade compõe nos lugares, o território informacional.

Como vimos anteriormente a incorporação das tecnologias de geolocalização aos dispositivos móveis de comunicação, permite que o próprio deslocamento seja demarcado ou rastreado espacialmente, ou então, que o espaço seja demarcado durante o deslocamento, associando novas camadas informacionais ao trajeto.

No capítulo anterior dissertou-se sobre o caminhar como prática estética. Seja da deriva situacionista, na Land Art, na deambulação surrealista ou nas incursões dadaísta, o caminhar estético buscava tanto investir de significações o espaço quanto deixar-se ser tomado por ele através da imersão sensorial. Mark Tuters e Varnelis (2006) consideram que as mídias locativas, retomam a centralidade do corpo na apreensão do espaço, em relação à experiência descorporificada da Net Art, que utiliza a tela como interface. Nas mídias locativas o corpo é a própria interface que capta e transmite dados informacionais através da mobilidade.

Por exemplo, quando a ferramenta Transborder Imigrattion Tool mapeia o território e adiciona camadas de informação para identificar as potenciais áreas de perigo para os imigrantes, indicando caminhos, hospedagem, alimentos, alimentos, água, etc. Há aí, uma demarcação territorial que reconfigura a caminhada. Na obra Can You See me Now?, 
a possibilidade de identificar jogadores se deslocando em uma mapa, modifica completamente a rota de outros jogadores, além disso o áudio transmitido em tempo real, detona uma espécie de catarse coletiva e faz com que os jogadores se rearticulem para mudar de estratégias de fuga e perseguição.

A questão da mobilidade, central para a discussão do desenvolvimento urbano, é retomada com a incorporação das mídias locativas e das mídias móveis. André Lemos aponta três dimensões fundamentais da mobilidade: o conceito de desterritorialização (DELEUZE \& GUATTARI, 1997), a dimensão física (corpos, transportes) e a informacionalvirtual (informação). Essas três esferas se inter-relacionam e têm impactos diretos entre si e nos espaços de fluxos. Nesses termos, a mobilidade nunca é neutra, nunca é apenas o percurso de um ponto a outro, devendo ser lida como potência e desempenho. A potência e o desempenho derivam sobretudo da acessibilidade: os que podem se movimentar mais facilmente pelo ciberespaço, têm maior autonomia para o deslocamento físico e vice-versa. A mobilidade portanto, é uma forma de produção de lugares. (LEMOS, 2010)

Não se pode portanto, dissociar informação, mobilidade, espaço e lugar. A mobilidade física de amplia com a mobilidade informacional. A "internet pingando nas coisas' com os dispositivos móveis, amplia a mobilidade em suas dimensões física e informacional. A mobilidade não é mero percurso de um ponto a outro, ela é politizada, revela formas de poder, controle, monitoramento e vigilância. Na atual cultura da mobilidade a potência de mobilidade varia, portanto, de acordo com o grupo social, segundo estruturas de poder.

Quando mapeamos a obra Megafone.net, percebemos no caso específico dos motoboys, uma classe que consegue praticamente "perfurar" o fluxo lento e a falta de mobilidade física na cidade de São Paulo e promover uma verdadeira rede de apoio, em tempo real, sobre as condições de trânsito, dificuldades enfrentadas, melhores caminhos, etc.:

"Em uma cidade com quase 11 milhões de habitantes e 4.5 milhões de carros, 32 mil táxis e congestionamentos de tráfego com mais de 100 quilômetros, não raro, cruzar a cidade pode demorar mais de duas horas. Somente um grupo na maior cidade da América do Sul parece imune a tais frustrações e atrasos: o exército audaz dos mensageiros da motocicleta conhecidos como 'motoboys'. (...) Muitos motoboys, especialmente mais novos, veem-se como os espíritos livres ou cowboys urbanos ('Vida Loka'), desafiando as convenções da sociedade e invejados pelos assalariados padrão metidos em carros e 
escritórios. Todos odeiam os motoboys exceto quando necessitam deles, disse Caíto Ortiz, diretor de 'Motoboys: Vida louca'. (ROHTER apud. SCHWARZ, 2009, p.55)

Os motoboys transitam em meio a esses dois tipos de mobilidade: a física e a informacional. As assimetrias tecnológicas do transporte (mobilidade física) e da comunicação (mobilidade informacional) tornam-se mutuamente funcionais, gerando valor pela exploração do tráfego sobrecarregado das metrópoles. Dessa rede viva de agentes móveis, emergem matizes de uma "luta de classes" entre os que podem se mover rapidamente e agem em meio a uma rede móvel (os motoboys) e aqueles que são mais lentos ou regulados pelo trânsito (os motoristas de carros ou os pedestres). $\mathrm{Na}$ cultura da mobilidade, radicaliza-se a oposição entre estas velocidades, entre os que se movem em um meio mais lento e as redes flexíveis, os espaços modulares, os fluxos imateriais, as ondas virais. (SCHWARTZ, 2009)

A mobilidade é um Ícone da pós-modernidade e uma vantagem disputada por indivíduos que competem em meio a territorialidades urbanas. O conceito de território como constituinte da mobilidade urbana, amplia a noção de mobilidade em meio a essas disputas por acesso, por informação e por deslocamento.

Para a compreensão dos aspectos comunicacionais, políticos e sociais das mídias locativas é fundamental entender como se criam as zonas de controle informacional, territorializações e funções eletrônico-digitais nos lugares do "mundo real".

Todo lugar é composto por diversas disputas por acesso e controle, ou seja, territorializações. E todo território trata de zonas de controle no interior de fronteiras, sejam elas, física, econômica, subjetiva, política, cultural, pessoal. É dessa tensão entre diversas fronteiras que emerge a dimensão local do processo de socialização: Os lugares são produzidos pela sociedade em sua relação territorial, mediando a nossa relação material e simbólica com o mundo. (LEMOS, 2009).

A formação dos territórios informacionais pelas mídias locativas e pela internet das coisas promove constantemente a formação de novas territorialidade urbanas e tensiona, aumenta, transforma as fronteiras dos lugares comuns. Firewalls, bolhas informacionais, mobilidade, demarcações, mapeamentos, RFID, realidade aumentada, são novos agentes de produção de sentido nessas bordas e é na ruptura dessas bordas que emergem as disputas em torno das formas atuais de vigilância, controle e monitoramento, mas também de transformação do cotidiano compartilhado. 


\subsection{2 - Vigilância e controle}

"Não há necessidade de ficção científica para conceber um mecanismo de controle que forneça a cada instante a posição de um elemento em meio aberto, animal numa reserva, homem numa empresa (coleira eletrônica). Félix Guattari imaginava uma cidade onde cada um pudesse deixar seu apartamento, sua rua, seu bairro, graças ao seu cartão eletrônico, que removeria qualquer barreira; mas, do mesmo modo, o cartão poderia ser rejeitado tal dia, ou entre tais horas; o que conta não é a barreira, mas o computador que localiza a posição de cada um, lícita ou ilícita, e opera uma modulação universal"( DELEUZE, 1992, p.223).

A questão da ubiqüidade da Internet das Coisas, ou seja, de um meio que permeia todos os outros e cria uma base continua e extensiva de acesso, permite por exemplo que esse sistema seja utilizado para a vigilância e controle.

Se os aparelhos de Estado se utilizam desta extensão de acesso, para controlar dados individuais e coletivos, sensores remoto, vigilância, etc. O setor corporativo das redes sociais age por nuvens ou bolhas informacionais. Os objetos fazem parte da esfera mais primordial de interação do homem com o mundo. Os objetos conectados entre si e capazes de coletar, transmitir e organizar dados a partir de sua interação com humanos, podem reunir "amostragens" ou perfis de consumo, que são organizados e agrupadas em bancos de dados.

As massas, por sua vez, tornam-se amostras, dados, mercados, que precisam ser rastreados, cartografados e analisados para que padrões de comportamentos repetitivos possam ser percebidos.

Em um artigo intitulado "Post-Scriptum sobre as Sociedades de Controle", o filósofo Gilles Deleuze (1992) indicou os aspectos definiam a Sociedade Disciplinar a partir da obra de Focault e as definições de uma nova sociedade que a sucedia: A Sociedade de Controle. Para Focault as sociedade disciplinares, fruto da modernidade, têm como pressuposto, gerir as instituições totais: família, escola, fábricas, hospitais, prisões (esta é o meio analógico de todas as outras) e dessa forma cada indivíduo passa de um espaço fechado para o outro. 0 projeto ideal dos meios de confinamento era visível a partir das fábricas: "concentrar, distribuir no espaço, ordenar no tempo, compor no espaço-tempo uma força produtiva, cujo efeito deve ser superior a soma das forças 
elementares", para Focault as sociedades disciplinares podem ser situadas num perîodo que vai do século XVIII até a Segunda Grande Guerra, declinando durante a segunda metade do século XX, e dando lugar ao surgimento da Sociedade de Controle.

A Sociedade de Controle é caracterizada pela "ausência de limites definidos" (a rede) e de "duração contínua". Se na Sociedade Disciplinar cada indivíduo é demarcado a partir de um nome que o individualiza e de um número que determina sua posição em meio a uma massa, na Sociedade de Controle, é uma senha (cifra) que marca seu acesso ou a negação à informação. A distinção indivíduo(nome)-massa(número) dá lugar ao diviso e aos bancos (amostragens) nas Sociedade de Controle.

Deleuze opera a distinção entre disciplina e controle, a partir das terminologias utilizadas para definir os meios de produção que as compõe, assim a Sociedade Disciplinar, opera por analogia: suas estruturas são analógicas ao modelo da prisão; “Ao passo que os diferentes modos de controle, os "controlatos", formam um sistema de geometria variável cuja linguagem é numérica” (DELEUZE, 1992, p.220)

Estas terminologias não são casuais e se as associarmos aos modos de produção vigentes em nosso mapeamento veremos que os arquitetos de fato, buscam a formalização de um espaço de variáveis em meio a uma linguagem numérica. Ao passo que os artistas do nosso mapeamento operam por amostragens espacias ou localidades interligadas em bancos de dados.

Os diversos dispositivos digitais estão nos colocando em meio a formas sutis de controle e vigilância. Os dados que "produzimos" em rede são freqüentemente indicadores de quem somos e o que queremos desse novo mercado. A ubiqüidade aplicada à Internet das Coisas, libera essas informações, que antes eram restritas a interação entre homem e tela do computador, para os mais diversos artefatos da vida cotidiana que passam a produzir informação: "the essential qualities of the ubiquitous network society vision are invisibility and pervasiveness" (GOW apud. LEMOS, 2009, p.2).

O lugar, na fase da "internet das coisas", é uma somatória de suas dimensões física, social, cultural, simbólica e dos novos banco de dados eletrônicos aí acoplados. Bruno Latour diz que as coisas são um foco para o nosso tempo, um foco que exige a atenção das artes: " As Coisas são conjuntos emaranhados de questões controversas, e não apenas objetos afastados de nossas paixões políticas. Os enredos de coisas e o engajamento de ativistas, artistas, políticos e intelectuais para montar esta linha teórica não é suficiente e nem é eloqüência que o uso de todas as tecnologias exige, em 
especial a tecnologia de informação e a possibilidade de as artes para representem de novo, quais são os desafios nossos comuns". (LATOUR apud. TUTERS e VARNELIS, 2006, p.7)

A arte atravessa mudanças paradigmáticas ao incorporar em sua linguagem novas tecnologias e as discussões que elas levantam. A vigilância e o controle são os exemplos mais atribuídos às mídias locativas, por exemplo, por utilizarem tecnologias que foram criadas para este fim, por estarem em todas as partes, invisíveis. A nova vigilância da sociedade de controle está em todos os lugares e, ao mesmo tempo, em lugar nenhum.

Noventa por cento das tecnologias que permeiam nosso cotidiano, estão tão incorporadas à vida diária e aos objetos, que não nos damos conta dos processos técnicos e tecnológicos que envolvem seus meios de produção. Dessa mesma forma a atual fase da internet das coisas, agrega camadas informacionais "invisíveis" aos objetos. (TUTTERS, 2006).

Embora o campo da Arte contemporânea, como crítica da cultura, busque delinear novos caminhos para estes artefatos, ainda enfrentam as questões, acerca da ampliação de suas fronteiras ao incorporar coletivos de artistas de várias formações e ao incorporar e desenvolver novas tecnologias de uso cotidiano, a arte sai da plataforma representacional da tela, dos espaços de galerias e lança seu olhar para rua, para a pervasividade e ubiqüidade das tecnologias informacionais e os objetos cotidianos, que a envolvem.

Camadas de informação envolvem tanto os objetos quanto as pessoas que os portam e se tornam corpos e objetos informacionais conectados em rede, passíveis e vigilância, controle, e como processos informacionais, são também passíveis de programação e é nesse sentido que vigilância e o controle se tornam invisíveis e presentes nas camadas mais improváveis da vida humana.

Pesquisas que desenvolvem o implante de chips e etiquetas RFID em seres humanos, leitura biométrica de corpos, Inteligência artificial, computadores de $\mathrm{DNA}^{56} \mathrm{e}$ a primeira animação feita com átomos criada pelo centro de pesquisas da IBM, tendem a considerar que o próprio phylum orgânico está sendo manipulado como um phylum maquínico (DELEUZE, 1997), programando-os como dados informacionais e se

\footnotetext{
${ }^{56}$ Leonard Adleman da University of Southern California;
} 
atualmente a arte e as mídias locativas se ocupam das camadas informacionais relativas aos objetos essas tecnologias tendem a se voltar também ao corpo, aos processos biológicos e as camadas mais invisíveis e mais imediatas: corpos informacionais.

McLuhan viu os sistemas de comunicação por satélite, tanto como uma extensão do sistema nervoso humano e como um ponto de não retorno. A infraestrutura de satélite cria conectividade de cima. A infraestrutura de RFID cria conectividade abaixo . E nós estamos "entre" esses espaços. Para os satélites, bancos de dados e sistemas de georreferenciamento, no entanto, "nós" somos um espaço de informação como qualquer outro . Então, quem ou o que vai fazer a interpretação de todos esses dados? E como será a produção de significado nesses espaços de informação?

A implementação da Internet das Coisas desenvolve a capacidade de associar dados informacionais às superfícies de objetos e espaços interativos, permitindo sua reprodução na vida cotidiana desses espaços. Assim como foi com a eletricidade, a computação, o processamento de informações e os computadores se tornarão, nos objetos, tecnologias "invisíveis", tão incorporados que estarão ao nosso cotidiano. Em lugares onde processos computacionais desaparecem em objetos, edifícios, carros, produtos de consumo, e as pessoas tornam-se espaços de informação.

O desaparecimento do computador ${ }^{57}$, ou esse "download" informacional nos objetos cotidianos, levanta algumas questões: Como traçar e conservar os fluxos de informação em tempo real? Quais métodos para definir o que são e o que não são dados nesse espaço de fluxos? Como será a sincronização de dados entre objetos?

Estamos entrando em uma época onde o ambiente se tornou a interface. Devemos aprender de novo como "fazer sentido" ou seja, ter a capacidade de ler dados como dados e não ruído. Os artistas sempre exploraram as condições para a mudança tecnológica, aplicações e serviços como parte da linguagem e técnica dos processos artísticos. Na internet das coisas o processo poético de criar sentido e experiências não acontece só no nível de design, mas encontra-se no centro de toda a arquitetura de sistemas.

Perigos como monitoramento, vigilância e invasão de privacidade e apropriação de dados são perfeitamente possíveis na Internet das Coisas. Porém, apenas uma

\footnotetext{
${ }^{57}$ The Disappearing Computer (DC) é o nome dado a uma iniciativa da Tecnologias futuras e emergentes (FET) dentro do programa IST Europeu, que viabiliza meios de implantar o projetos de Internet das Coisas. Disponível em: http://www.i3net.org/ser_pub/services/dc/. Acesso em: outubro de 2013.
} 
apropriação crítica, tática e ao mesmo tempo política, social e estética, poderá evitar a instrumentalização comercial e policial das mídias locativas que manteriam o usuário na posição de simples receptor massivo. (LEMOS, 2009, p.94).

Em “Declaração" (2014), Negri e Hardt identificam no mínimo 4 formas de subjetividade engendradas e atualizadas pelo capital na contemporaneidade e o afeto predominante que move cada uma delas: o endividado sente-se culpado; o sujeito mediatizado se deslumbra; o representado é apático e o sujeito securitizado sente-se amedrontado. A "indústria do medo" produz esse afeto comum de uma sociedade que adota o modelo prisional e se auto-vigia constantemente. A própria arquitetura reflete esses afetos: câmeras de vigilância pelas ruas, grandes muros, portões, cercas, carros blindados, catracas, portas giratórias, cancelas, alarmes e biometrias de todo tipo. A escola, o trabalho e a vida pública seguem a mesma lógica do sistema carcerário e a prisão cresce, por dentro e por fora. Principalmente pelas ruas. A alternativa proposta por Negri e Hardt para dissolver estas subjetividades é a constituição do comum, trocar o medo e o individualismo pelo "risco" da convivência é o primeiro passo.

\subsection{1 - Percepção e produção mediadas}

Em Linguagens Líquidas na Era da Mobilidade Santaella, 2007 propõe que a complexidade cultural e comunicacional das sociedades contemporâneas advém da simultaneidade de seis formas de cultura que coexistem: a cultura oral, a escrita, a impressa, a cultura de massa, das mídias e da cibercultura. Santaella adota como parâmetro a introdução gradativa de novos meios de produção, armazenamento, transmissão e recepção de signos introduzidos historicamente na cultura ocidental. Sendo que a tendência de cada meio é cumulativa e integrativa, ou seja, o novos meios inovam e se integram as antigas linguagens comunicacionais de cada era. Dessa forma todos os meios tecno-científicos anteriores são incorporados e mesclados nas novas formas de produção tecnológica que surgem em um novo meio técnico-científicoinformacional.

Tais adjacências históricas são fortemente articuladas pela cibercultura, expressando e produzindo, simultaneamente mutações nos modos de se perceber, conceber e habitar o tempo e o espaço. Dessa forma cada nova linguagem que surge no contexto técnico ou tecnológico de uma época é incorporada, transformada e se torna híbrida com seu meio anterior. 
Em nosso contexto histórico, portanto pós-industrial, a hibridização entre homem e máquina conectados em rede e em tempo real, promove um corte na temporalidade até então estabelecida pelas sociedades disciplinares(DELEUZE, 1990) ou industriais. A velocidade em que se atualiza e virtualiza este tempo atravessa nossa apreensão, entendimento e produção dos meios políticos, geográficos, estéticos e tecnológicos. A mobilidade, que resulta da associação entre dispositivos móveis conectados em rede, promoveu a produção e o compartilhamento sem precedentes, de imagens tecnológicas.

Para Guatarri a tecnociência e a informática são produtos e produtores maquínicos de subjetividade que atravessam e produzem novas formas de existência. Dessa forma cada sociedade produz seu meio tecnocientífico, que por sua vez subjetiva e torna visível novas formas de realidade. Dessa forma, "Se cada sociedade tem seus tipos de máquinas, é porque elas são o correlato de expressões sociais capazes de thes fazer nascer e delas servir como verdadeiros órgãos da realidade nascente" (PARENTE, 2011. p.15)

Em Máquinas de Visão, Paul Virilio distingue três regimes de imagens que se articulam e prevalecem sobre determinadas épocas (eras), a saber: A era da Lógica formal, ligada ao campo de representação da perspectiva renascentista, marcada pela representação de conteúdos fechados de espaço-tempo; a era da lógica dialética introduzida pela reprodutibilidade técnica das obras de arte: a fotografia e o cinema que coloca em relação o real e o fictício promovendo novas relações dialéticas sobre a concepção de representação sujeito-objeto e seu descolamento do real; e a era paradoxal em que predominam as imagens numéricas, existentes e inexistentes ao mesmo tempo. Virilio define as imagens da era paradoxal da seguinte forma:

"Da imagem em tempo real que domina à coisa representada, subvertendo a própria noção de realidade. Daí a crise das representações públicas tradicionais (gráficas, fotográficas, cinematográficas...) em benefício de uma apresentação, de uma presença paradoxal, tele presença à distância do objeto ou do ser que supre a própria existência, aqui e agora" (VIRILIO, 1980).

$\mathrm{Na}$ última década, com as tecnologias de georreferenciamento, as imagens virtuais puramente numéricas ou aquelas com referencial na materialidade das coisas, se vinculam às coordenadas do globo terrestre, mas com um índice de materialidade inteiramente novo, que se estabelece como metadado das imagens. Conforme vimos anteriormente, este terceiro espaço, cíbrido, foi definido por Peter Anders justamente a partir desta integração entre o meio físico e o virtual. 0 meio virtual atua na 
temporalidade da linguagem e se atualiza constantemente e adere na materialidade a noção de fluxo constante, mobilidade.

A super-produção de imagens possibilitada pela difusão sem precedentes de dispositivos móveis (celulares e tablets), acoplados com câmeras e conectados em rede, promoveu a portabilidade e a mobilidade de uma super-produção de mídias digitais, que são imediatamente inscritas em rede e associadas a uma localização, promovendo a comunicação instantânea. Como previu Baudrilard em 1972, em seu texto Requién for a Media, a verdadeira mídia é a transmissão imediata, dada e recebida, falada e respondida, móvel no mesmo espaço e tempo, recíproca e antagônica. (BAUDRILARD, 1972).

Nesse contexto as câmeras digitais passam de dispositivos de registro para dispositivos de projeção social. O fotógrafo Joan Fontcuberta em seu manifesto pósfotográfico identifica um novo ator nesta rede, o cidadão fotógrafo:

" Um dos principais jornais de Hong Kong despediu, faz pouco, os seus oito fotógrafos fixos que cobriam as notícias locais; em troca, distribuíram câmeras digitais entre o coletivo de entregadores de pizza. A decisão empresarial era sensata: é mais fácil ensinar a fazer fotos aos ágeis e escorregadios entregadores do que conseguir que os fotógrafos profissionais sejam capazes de contornar os engarrafamentos infernais de Hong Kong e consigam chegar a tempo à notícia. Os porta-vozes do setor, obviamente, ficaram loucos: como é possível que se renuncie à qualidade que é garantida pelos profissionais com experiência? Mas há de se convir que mais vale uma imagem defeituosa tomada por um amador do que uma imagem talvez magnífica, mas inexistente. Saudemos, pois, o novo cidadãofotógrafo." (FONTCUBERTA, 2011.p.1)

Fontcuberta sinaliza como funciona a "radical criação pós-fotográfica" onde a mobilidade se torna capital para a super produção de conteúdos capturados a partir do cotidiano. A super produção de imagens entra em um novo regime de visibilidade e de circulação onde a "gestão" de significados e códigos não são ainda totalmente capturados, mas ainda em campo de batalha. Se encontram naquele campo intermediário que Focault situa entre as ordens empíricas e as interpretativas:

"Os códigos de uma cultura - aqueles que regem sua linguagem, seus esquemas perceptivos, suas trocas, suas técnicas, seus valores, a hierarquia de suas práticas - fixam, logo de entrada, para cada homem, as ordens empíricas com as quais terá de lidar e nas quais se há de encontrar. $\mathrm{Na}$ outra extremidade do pensamento, teorias científicas ou interpretações de filósofos explicam por que há em geral uma ordem, a que lei geral obedece, que princípio pode justificá- 
la, por que razão é esta a ordem estabelecida e não outra. Mas, entre essas duas regiões tão distantes, reina um domínio que, apesar de ter sobretudo um papel intermediário, não é menos fundamental: é mais confuso, mais obscuro e, sem dúvida, menos fácil de analisar." (FOCAULT, 2000. p10)

As tecnologias da imagem marcadas pelo regime social no qual se produzem, são marcadas por relações de força que podem tanto direcionar seu uso para a homogeneização universalizante (territorialização) como para a heterogeneização singularizante (desterritorialização) da subjetividade que libertam ou não, o real capturado pelas representações dominantes.

Aqui se abre uma distinção entre as mídias fechadas, tais como televisão e rádio, e o compartilhamento na rede. 0 espaço cíbrido não atua da mesma forma que o meio informacional imediatamente anterior a ele: as mídias de massa (TV, rádio, jornais, cinema, etc.), e reage de forma singular em relação ao espaço público e à opinião pública, formada pela cultura de massas. Como vimos antes, socialmente as tecnologias informacionais não atuam na forma unidirecional "um-todos" e rompem com a hegemonia midiática de um único discurso sobre o que é o público e sobre qual é a opinião pública: o consumo massivo é centralizado nas emissoras de rádio e televisão e o consumo a-centrado que tende à segmentação, hibridização e diversificação de dados informacionais.

o acréscimo da produção de imagens ocorrido durante a transição entre a fotografia analógica e digital, produz um cotidiano onde é filmado ou fotografado o tempo todo e repetidas vezes, e estas imagens inscritas em uma rede em tempo real, gerando terabites de informação imagética a cada dia. Um exemplo citado por Didi Huberman em entrevista, é o do atentado do 11 de Setembro. Muitas imagens foram censuradas ali, causando uma sub-exposição de pontos de vistas que pudessem alterar a percepção do ocorrido. A super exposição de alguns ângulos específicos impuseram o lugar-comum de um acontecimento, apagando sua singularidade, e direcionando um discurso homogêneo para o acontecimento, tornando as imagens muito próximas ao que Deleuze chamaria de Imagens-Clichês. Esta abrangência (estar em vários lugares ao mesmo tempo) pode ser tanto uma fator de saturação que esvazia o sentido da imagem em um único e homogêneo ponto de vista, uma voz dominante, como também um fator de amplitude, quando se multiplicam os pontos de vista e a produção fotográfica é capaz de gerar inúmeros contextos a partir de um evento. 
Os índices históricos de uma imagem delimitam o que se torna visível em uma determinada época e cada época é carregada pelas imagens que the são sincrônicas: "a verdade está carregada de tempo até o ponto de explodir. (...) Não é que o passado lança sua luz sobre o presente ou que o presente lança luz sobre o passado; mas a imagem é aquilo em que o ocorrido encontra o agora num lampejo, formando uma constelação" (BENJAMIN, 2006, p.505)

As imagens dialéticas são para Benjamin o campo de significação onde o tempo histórico se adensa e é constantemente revisto e ampliado. Em sua relação dialética com o "agora" do olhar que transborda a imagem. Um método crítico que opera por fragmentos, (re)montagens (o Atlas de Didi-Huberman) e faz ler o instante e reconhecer o tempo histórico em que se vive, re-atualizado em cada olhar.

A imagem para Benjamin é este adensamento de sentidos que entrelaçam os tempos históricos em constante atualização. Quando estes significados se singularizam na imagem, se assemelham à noção de punctum das fotografias históricas de Roland Barthes: "isto está morto e vai morrer" (BARTHES, 2011. p.104). Não se trata de uma morte que se encerra no momento fotográfico, um tempo esmagado, "o punctum de uma fotografia é esse acaso que nela me fere, mas também me mortifica, me apunhala". (BARTHES, 2011. p.104).

Para Didi-Huberman (1999) há um deslocamento do conceito de imagem dialética para o de imagem crítica. Em o que Vemos e o que nos Olha, ele desloca o campo de sentido para o espaço entre o observador e o observado. Este entre-meio das coisas, é o fora da imagem, que num sentido fenomenológico, atravessa os sentidos do observador e é atravessada por ele:

\footnotetext{
" Não há que escolher entre o que vemos (com sua conseqüência exclusiva num discurso que o fixa, a saber: a tautologia) e o que nos olha (com seu embargo exclusivo no discurso que o fixa, a saber: a crença). Há apenas que se inquietar com o ENTRE. (..) É o momento em que o que vemos justamente começa a ser atingido pelo que nos olha. É o momento em que se abre o antro escavado pelo que nos olha no que vemos" (DIDI-HUBERMAN apud. DA COSTA, 2009)
}

No contexto da fotografia digital, a expansão dos smartphones permitiu a expansão e popularização das fotografias do cotidiano. Ainda na década de 70 Susan Sontag já afirmava que a necessidade de confirmar a realidade e enfatizar a experiência vivida mediante o uso da fotografia, era um "consumismo estético" amplamente difundido, que 
promovia uma super estetização do cotidiano, que atualmente é afirmada e ampliada pela fotografia digital.

A fotografia digital, produzida por qualquer smartphone e compartilhada imediatamente em rede, modifica a forma como nos relacionamos com as imagens. Fontcuberta em seu Manifesto Pós-Fotográfico sinaliza que as imagens pós-fotográficas não são mais recordações para se guardar, mas para "postar" e compartilhar.

O compartilhamento se torna mais importante que o próprio conteúdo da imagem, saturando e duplicando o mundo em imagens que são inseridas em uma demarcação geográfica.

No contexto de super-produção Fontcuberta declara sobre a responsabilidade do artista: "se impõe uma ecologia do visual que penalizará a saturação e incentivará a reciclagem de sentidos" (FONTCUBERTA, 2011). Nesse sentido não é a produção de imagens em si que interessa, mas a reciclagem e a atualização constante de novos significados. Lev Manovich em seu projeto SelfCities.net sobrepõe uma série selfies tomadas em várias regiões do globo onde predominam a mesma posição da câmera e a mesma distância e ângulo dos braços de modo que sobrepostas, estas imagens parecem um desfoque de uma única pessoa. ${ }^{58}$ Embora o selfie se insira em um regime de visibilidade de códigos inscritos na cultura, que busca projetar a "auto-imagem" do selfie para as redes, esta sobre-exposição as torna opaca. Operando o esvaziamento de um contexto, tomado repetidamente sob um único ponto de vista, onde não há outras referências senão a própria imagem.

Ainda no regime de visibilidade e circulação das imagens pós-fotográficas há um deslocamento do regime de visibilidade e circulação das Imagens provocado tanto por aspectos internos à imagem, que buscam "corrigir" através de algorítimos as distorções provocadas pela captura digital, que mediam as imagens antes mesmo de se tornarem visíveis, quanto em seu aspecto externo, da circulação e visibilidade, também circunscritos por algorítimos que delimitam a visibilidade do que é postado em rede. Outro exemplo, é a capacidade de gerar metadados a partir da leitura massiva dessas imagens.

${ }^{58}$ Disponivel em: www.selfiecity.net Acesso em: 15/11/2015; 
Estes dois aspectos, colocam a imagem pós-fotográfica em relação ao seu fora, àquele aspecto que Didi-Huberman afirmou estar entre a imagem em si e seus interlocutores. Trata-se de um fazer político estético, em construção, que transforma o próprio regime de visibilidade as artes, toma uma proposição política. Para Jacques Rancière, "as práticas artísticas são 'maneiras de fazer' que intervêm na distribuição geral das maneiras de fazer e nas suas relações com maneiras de ser e formas de visibilidade". (RANCIÈRE, 2009. p.17). O fazer pós-fotográfico revoga a estética dos regimes imagéticos anteriores, desloca sua partilha e determina novas relações de temporalidade e significações dentro das imagens.

O campo de batalha e as máquinas de guerras que este fazer traça, estão ainda em aberto, não totalmente digeridos e capturados, mas tendem no contexto pós-industrial de um capitalismo intensificado, em que vivemos, a ser capturados por aquela homogeneização universalizante (territoriaização), basta ver o exemplo do projeto Internet.org, idealizado por Mark Zuckerberg, para se ter uma noção mínima destas articulações. Longe de ser mera política individual, as redes sociais, gerenciam as relações humanas, criam hábitos de acesso a rede, enquanto o Google distribui "verdades" o Facebook gerencia as relações humanas, sob a aparente neutralidade das redes a fórmula mecanizada dos algoritmos permitem que investidores e acionistas lucrem com cada micro-movimento em rede (curtir, compartilhar, postar, adicionar amigos) e revela um novo tipo de negócio: o negócio das relações humanas, onde a moeda de troca são os usuários ${ }^{59}$.

\section{3 - Práticas De Compartilhamento Nos Espaços Cíbridos}

"O problema da inteligência coletiva é descobrir ou inventar um além da escrita, um além da linguagem tal que o tratamento da informação seja distribuído e coordenado por toda parte, que não seja mais o apanágio de órgãos sociais separados, mas se integre naturalmente, pelo contrário, a todas as atividades humanas, volte as mãos de cada um." (LÉVY, P. 2007, p. 17).

Se nos capítulos anteriores, buscou-se dissertar sobre as formas de percepção, pensamento e produção dos espaços cíbridos. Nesta estapa final, busca-se apontar para

\footnotetext{
${ }^{59}$ Para informações detalhadas ver o e-books: No Aquário do Facebook e The Dark Side of Google - do Coletivo Ippolita. Disponivel em http://networkcultures.org/blog/publication/no-13-the-dark-side-of-google-ippolita/. Acessado em 27/07/2015.
} 
iniciativas que têm alterado a formas compartilhamento nesses espaços.

O capitalismo mundial passa por profundas mudanças em suas bases produtivas a partir da tecnologia digital. Em toda sociedade capitalista as elites financeiras detém para si um conjunto de técnicas ou tecnologias, capazes de gerar e concentrar riqueza: "As sociedades humanas se organizam como sociedades tecnodependentes" (SILVEIRA, 2000). Boaventura, resume assim o neoliberalismo:

"Eis a minha definição de globalização: é o conjunto de trocas desiguais pelo qual um determinado artefato, condição, entidade ou identidade local estende a sua influência para além das fronteiras nacionais e, ao fazê-lo, desenvolve a capacidade de designar como local outro artefato, condição, entidade ou identidade rival." (SOUZA SANTOS, 2002).

Globalização, que é em si, uma nova fase da acumulação capitalista intensificada enraíza a fratura social ente "info-ricos" e "info-pobres". Nesse contexto, de hegemonia neoliberal e de pensamento seria possível combater a pobreza, sem a utilização de tecnologias da informação? Sem produzir ainda mais "tecno-dependência" dos países pobres ou em desenvolvimento?

O movimento Software Livre, que defende a abertura e códigos de programas e sistemas operacionais de computadores e outros dispositivos, assume que a prática de inclusão digital é urgente para a apropriação coletiva dos meios de produção das tecnologias, pois sem a prática de inclusão, a fratura social entre os 'info-ricos' e os 'info-pobres' tende a se intensificar ampliando a miséria e a concentração de renda:

"A idéia de transformar a inclusão digital em política pública consolida no mínimo quatro pressupostos. Primeiro, é o reconhecimento que a exclusão digital amplia a miséria e dificulta o desenvolvimento humano local e internacional. A exclusão digital não se trata de uma mera conseqüência da pobreza crônica, mas torna-se fator de congelamento da condição de miséria e de grande distanciamento das sociedades ricas. Segundo, é a constatação que o mercado não irá incluir na era da informação os extratos pobres e desprovidos de dinheiro. A própria alfabetização e escolarização da população não seria massiva se não fosse pela transformação da educação em política pública e gratuita. A alfabetização digital e a formação básica para viver na cibercultura também dependerão da ação do Estado para serem amplas ou universalistas. Terceiro, a velocidade da inclusão é decisiva para que a sociedade tenha sujeitos e quadros em número suficiente para aproveitar as brechas de desenvolvimento no contexto da mundialização de trocas desiguais e, também, para adquirir capacidade de gerar inovações. Quarto, é a aceitação de que a liberdade de expressão e o direito de se comunicar seria uma falácia se ele fosse apenas para a minoria que tem acesso a comunicação em rede. Hoje, o direito à comunicação é sinônimo de 
direito a comunicação mediada por computador. Portanto, trata-se de uma questão de cidadania." (Software Livre Brasil) ${ }^{60}$

A inclusão digital como combate a pobreza e a tecnodependência, pressupõe portanto, que a exclusão digital amplia a miséria e dificulta o desenvolvimento humano, além de torna-se um fator de congelamento da miséria, na medida em que restringe 0 acesso a livre circulação de conhecimento e tecno-saberes que dão acesso aos meios de produção de riqueza, conhecimento e inovação.

Não se trata de difundir um saber operacional, voltado apenas para o consumo massivo de dispositivos computacionais, mas sim da difusão de conhecimentos acerca das bases de programação, para que haja o entendimento e a apropriação das formas de operar, pensar e produzir as tecnologias que convivem intimamente com a vida de qualquer usuário. Portanto trata-se de uma questão de cidadania e acesso aos direitos básicos de riqueza social, acesso ao conhecimento e à informação.

No caso do Brasil tem-se realizado esforços governamentais para a adoção dos "softwares livres", tanto na administração direta, como em coletivos de inclusão digital. A atual revolução dos SL (Software Livre) deve-se a cultura do compartilhamento, potencializando a distribuição, a cooperação e a apropriação dos bens informacionais. 0 que está em jogo, no processo de inclusão digital das cidades expandidas é a apropriação social dessas novas tecnologias, para que o processo de inclusão democrática seja colaborativo e aponte para novas soluções na economia e no desenvolvimento compartilhado.

O Software Livre, compõe um dos movimentos mais importantes pela emancipação digital, junto com ele inúmeros movimentos vêm buscando articular e modificar as esferas da propriedade, desenvolver dinâmicas de horizontalização do trabalho, da produção e da renda, procurando formas de se articular diante a imensa concentração de renda, a que produção tecnológica gera.

Além do Software Livre vemos o surgimento de diversas práticas colaborativas que buscam driblar os grandes sistemas de crédito bancário, por exemplo, as organizações

${ }^{60}$ Para mais informações sobre o movimento Software Livre acessar: http://softwarelivre.org. acessado em: $12 / 02 / 2015$ 
de financiamento colaborativos que usam a lógica do crowdfunding ${ }^{61}$. Este termo designa o financiamento coletivo (crowdfunding) para obtenção de capital voltado para as iniciativas independentes de interesse coletivo, através da agregação de múltiplas fontes de financiamento, em geral pessoas físicas interessadas na iniciativa. Há também as práticas voltadas para a flexibilização da propriedade intelectual, como vemos com o Movimento Copylef, que contribuem para a difusão e o compartilhamento do conhecimento. Copyleft, significa direito de cópia e é uma estratégia para desarticular as legislações de direitos autorais, trata-se de uma licença que permite a livre circulação de qualquer obra que a adquira, seja ela literária, musical, informática, intelectual, etc. Esta mesma licença busca preservar os direitos à liberdade da obra à fim de que esta não seja apropriada para fins privados de lucro.

A área do design é uma das que mais tem contribuído para a cultura do compartilhamento e da produção de tecnologias 'abertas', a partir dos FAB-LABS e do Open Design . O que não significa que seus criadores deixem de lucrar, mas que suas produções sejam livres de direitos autorais ou então que possam ser distribuídas, compartilhadas ou recriadas livremente. O Movimento Maker, que surgiu aproximadamente em 2005 amplia a prática DIY (Do It Yourself) - faça você mesmo, e passa a criar a partir de dispositivos como o Arduino ${ }^{62}$, dispositivos informacionais descentralizados da rede de produção.

Um dos pensadores brasileiros a desenvolver o conceito de 'economia solidária' é o economista Paul Singer, que busca o acesso e a produção igualitários ao meios de produção:

"Entendemos por desenvolvimento solidário um processo de fomento de novas forças produtivas e de instauração de novas relações de produção, de modo a promover um processo sustentável de crescimento econômico, que preserve a natureza e redistribua os frutos do crescimento a favor dos que se encontram marginalizados da produção social e da fruição dos resultados da mesma. " (SINGER, 2002)

O ponto de partida para o desenvolvimento solidário, é o estágio atual de

\footnotetext{
${ }^{61}$ Para mais informações sobre 0 sistemas de crowdfunding, sugerimos a pesquisa na página: https://pt.wikipedia.org/wiki/Financiamento coletivo. Acesso em: 12/02/2015.

${ }^{62}$ Para mais informações sobre o Arduino, sugerimos consultar a página: http://www.arduino.com.br. Acesso em: 12/02/2015.
} 
desenvolvimento, ou seja, está inserido no capitalismo hegemônico. Esse patamar, pressupõe-se, que seja ultrapassado a cada inovação tecnológica, disputa de mercados entre empresas capitalistas e não capitalista, o movimento Software-livre, por exemplo. Esse desenvolvimento deve gradativamente se encaminhar para o segundo tipo de empreendimento que compreende as organizações horizontais e cooperativas de trabalho.

Quando a economia solidária formada por empreendimentos individuais, familiares e empreendimentos auto-gestionários, for hegemônica essa forma de trabalho será capaz de alterar o rumo do desenvolvimento tecnológico para visar o desenvolvimento auto-sustentável e a satisfação das necessidades consideradas prioritárias pela maioria. Dessa forma o desenvolvimento será pautado a partir da organização social dos mercados e não o contrário, como vimos anteriormente com as mercadorias fictícias. Embora o software-livre, como vimos, já opere a rearticulação do trabalho através do compartilhamento e auto-organização horizontal, pressupõe-se que todas as esferas da sociedade, possam se articular dessa maneira segundo a idéia de economia e desenvolvimento compartilhado, ou solidários.

Do ponto de vista social, o desenvolvimento solidário, prioriza o compartilhamento ao invés da concorrência capitalista. (SINGER, 2002). O Desenvolvimento capitalista é moldado pelos valores do livre funcionamento dos mercados, das virtudes de competição, do individualismo e do Estado mínimo enquanto o desenvolvimento solidário é o desenvolvimento realizado por comunidades de pequenas firmas associadas ou de cooperativas de trabalhadores, federadas em complexos, guiado pelos valores da cooperação e ajuda mútua entre pessoas ou firmas, mesmo quando competem entre si nos mesmos mercados.

Horizontalidade e cooperação são os princípios que norteiam a esfera do trabalho e da propriedade, rumo à uma nova possível fase do desenvolvimento compartilhado. 


\section{Considerações Finais}

O espaço, nossa primeira interface, assume tantos significados que é quase impossível tratar de sua conceituação, sem remontar a história do pensamento. As definições de espaço foram apropriadas por tantas áreas do conhecimento e cada uma, a seu modo, reconfigurou esse conceito de acordo com o meio técnico científico em que se inseriu. Assim temos o espaço geográfico, matemático, cartesiano, fenomenológico, arquitetônico, etc.

O desenvolvimento do espaço virtual veio apenas mais tarde, com o desenvolvimento das modos de produção tecno-científico-informacionais (SANTOS, 2000). Por se tratar de um campo, relativamente novo, e portanto não territorializado no campo de cada disciplina, este termo tem sido constantemente revisado, ampliado e recriado.

$\mathrm{Na}$ arquitetura, a incorporação desse espaço como meio de investigação metodológico e epistemológico, promoveu diversos tensionamentos nas bordas deste termo, por exemplo, com o conceito de Transarquitetura de Marcos Novak ou de Arquitetura Maquínica de Lars Spuybroek e mesmo o campo de possibilidades da interação entre DNA e espaço informacional para a arquitetura genética, que reconfigura não apenas o termo Virtual, mas toda a relação com o que temos definido historicamente como Natureza e espaço natural. Este mapeamento reuniu a primeira geração de arquitetos experimentais que incorporaram o meio virtual como linguagem e que, por isso, trataram de diversas maneiras de conceituar e dar forma ao espaço virtual. Este campo de força, o virtual, avançou na última década rumo à hibridização com o espaço físico. Dessa hibridização, emergiram, constelações de práticas híbridas nesse espaço: a implantação das tecnologias de geolocalização (GPS), com os dispositivos móveis, que se tornaram paulatinamente uma interface de relação com o meio urbano. Seja através da demarcação do espaço urbano com camadas informacionais (Qr-code e realidade aumentada), ou da criação de mapas urbanos criados colaborativamente e compartilhados em rede.

O mapeamento em mídias locativas buscou investigar, os campos de força desta hibridização, ou seja, como cada obra captou as potências e as possibilidades de ação destas tecnologias de localização, como por exemplo, a demarcação espacial através de 
tags sonoras capaz de criar zonas de compartilhamento sonoro, ou então a articulação estratégica de um grupo de pessoas se comunicando por meio de dispositivos móveis como no caso do Can You see me Now? - CYSMN? e até mesmo o hackeamento dos sistemas de Rfid, em ZAPPED!

Dessas formas híbridas de interação, pudemos distinguir pelo menos 3 terminologias que nos pareceram mais adequadas para definir o contexto de hibridização: espaços cíbridos (ANDERS, 2001), espaço pós-virtual (BEIGUELMAN, 2013) e espaço de fluxos (CASTELLS, 2000). Peter Anders cunhou o termo Cíbrido, para definir a continuidade entre espaço físico e virtual, ambos são formados de materialidades específicas, mas ainda sim são físicos, e portanto, extensão de uma mesma dimensão com características temporais diversas. Este termo nos pareceu adequado por não cindir de antemão dois espaços contíguos, embora o espaço virtual esteja como definiu Pierre Lévy, desterritorializado, ou seja, sem apropriação dos campos do conhecimento.

A partir dessa demarcação: o espaço cíbrido, partimos para as práticas agenciadas pelos espaços cíbridos. A mobilidade e a locatividade, as práticas de vigilância e controle e as práticas colaborativas. E embora as práticas de vigilância e controle sejam alarmantes e como vimos estamos de fato rumando para a configuração de sociedades de controle. São as práticas colaborativas e a elaboração constante do espaço comum, que apontam para as transições mais importantes na esfera dos modos de produção e trabalho. Vemos as fronteiras da propriedade serem flexibilizadas, utilizando o exemplo do projeto software livre, a partir das licenças copyleft e da economia solidária, bem como a propriedade. Com os sistemas de financiamento colaborativo, delineia-se uma nova forma de escapar dos grandes centros de crédito e com a prática do compartilhamento, estruturar novos modos de produção, que tentam minimamente horizontalizar essas esferas.

Não somo capazes de avaliar ainda, a extensão dessas práticas para a reestruturação global da tríade trabalho, renda e propriedade, no entanto, parece provável que a sociedade em rede, se articule de forma cada vez mais segmentada e específica.

Trata-se portanto de mais ponto de transição, para o qual, o conceito de territórios informacionais (LEMOS, 2004) expressa bem a necessidade de articular, desde já, as disputa territoriais na apropriação desses novos territórios. 


\section{Bibliografia}

ADAMS, M. (et.al). Can You See Me Now? A Citywide Mixed-Reality Gaming Experience. London: Blast theory. 2003. Disponivel em:

https://www.blasttheory.co.uk/wpcontent/uploads/2013/03/research_towards_a _ity_wide_mixed_reality_perf ormance.pdf. Acesso: 20/08/2015.

ALZAMORA, G. e CARVALHO, R. S. Relatos do Cotidiano no Canal Motoboy: Dimensões Estética e Política da Experiência Urbana. In: Revista do Programa de Pós-graduação da Escola de Comunicação da UFRJ. Vol. 14 $\mathrm{n}^{0} 1$. Rio de Janeiro: Universidade Federal do Rio de Janeiro, 2010. p. 67-81.

ANDERS, P. Extending Architecture Through Electronic Media. In: SPEED, C.; GRINSTED, G. (Eds.) Vol.01. London: Liquid Press, Plymouth, 2001.

ARANTES, Priscila; SANTAELLA, Lúcia (Orgs.). Estéticas tecnológicas: novos modos de sentir. São Paulo: Ed. EDUC/SP, 2008.

@ @rte e mídia: perspectivas da estética digital. São Paulo, SENAC, 2005.

BAMBOZZI, L.; BASTOS, M.; MINELI, R. (org.). Mediações Tecnologia e Espaço Público: Panorama Crítico da Artes em Mídias Móveis. São Paulo: Editora Conrad do Brasil, 2010.

BARTHES, Roland. A Câmera Clara: Nota Sobre a Fotografia. Tradução: Júlio C. Guimarães. 3ed. Rio de Janeiro: Nova Fronteira, 2011.

BASSETT, Keith. Walking as an Aesthetic Practice and a Critical Tool: Some Psychogeographic Experiments. In: Journal of Geography in Higher Education, Vol.28, N³, 2004, p.397-410.

BASTOS, M. Mapeamento Incompleto de Algumas Cartografias Celulares. Em: Geografias Celulares. Catálogo. Espacio Fundación Telefónica, Buenos Aires: 2009.

BAUDRILARD, Jean. Réquiem for the Media. 1972.

BAUDRILLARD, Jean. Tela Total: Mito-Ironias do Virtual e da Imagem. Juremir Machado da Silva (Org. Trad.). Porto Alegre: Sulina, 2005.

BEIGUELMAN, G; LA FERLA, J. (org.). Nomadismos Tecnológicos. São Paulo: Editora Senac São Paulo, 2011.

BEIGUELMAN, G. Mapas Diagramáticos Como Dispositivos Críticos da Hiperlocatividade. V!RUS, São Carlos, $n$.

8, dezembro 2012. Disponível em: http://www.nomads.usp.br/virus/virus08/?sec=3\&item=1\&lang=pt. Acesso: $12 / 08 / 2015$.

. 0 Fim do virtual. In: revista seLecT. São Paulo: Select, 2011. Disponível em:

http://www.select.art.br/article/reportagens e artigos/o-fim-do-virtual . Acesso: 08/2014.

. BASTOS, M., MINELLI, R., BAMBOZZI, L. Apropriações do (In)Comum). São Paulo : Instituto Sergio

Motta, 2009. Disponível em: http://hrenatoh.net/curso/textos/_artemov_port_pdf

. Arte pós-Virtual: Criação e Agenciamento no Tempo da Internet da Coisas e da Próxima Natureza. IN:

Seminários Internacionais Museu Vale (8:2013, Vila Velha, ES) Cyber-Arte-Cultura: A Trama das Redes.

Organização: Fernando Pessoa, Vila Velha, ES Museu Vale; Rio de Janeiro: Suzy Muniz Produções, 2013.

. Mapas Diagramáticos Como Dispositivos Críticos Da Hiperlocatividade. In: V!RUS, São Carlos, n.8,

dezembro, 2012. Disponível em: http://www.nomads.usp.br/virus/virus08/?sec=3\&item=1\&lang=pt. Acesso:

outubro de 2013.

BENFORD, S. Can you see me now? ACM Transactions on Computer-Human Interaction, New York: ACM, 2006. Disponivel em: http://dl.acm.org/citation.cfm?id=1143522. Acesso: 08/2014.

BENJAMIN, Walter. A Obra de Arte Na Era de sua Reprodutibilidade Técnica. In: Magia e Técnica, Arte e Política. Ensaios sobre a literatura e a história da cultura. Obras Escolhidas, Vol. I (trad.: Sérgio Paulo Rouanet). São Paulo: Brasiliense, 1985.

BOA-VENTURA, A. The rise of the 'location-aware' generation. Virose. Disponivel em http://www.virose.pt/vector/x_05/boaventura.html. Acesso: 01/11/2013.

BORGES, F. Na Busca da Cultura Espacial. Tese de Doutorado. São Paulo: PUC, 2013.

BORRIAUD, Nicolas. Radicante. $1^{\text {a }}$ Edição. Buenos Aires: Adriana Hidalgo Editora, 2009. 
BRUN, Jean-Paul. "Nature, art contemporain et société: le Land Art comme analyseur du social" Deuxième volume: "New York, déserts du Sud-ouest et cosmos, l'itinéraire des Lands Artists" Paris: L'Harmattan, 2006. BRUNET, K.; FREIRE, J. Cultura Digital e Geolocalização: a Arte Ante o Contexto Técnico-Político. In: VI Encontro de Estudos Multidisciplinares em Cultura, 2010, Salvador. VI Encontro de Estudos Multidisciplinares em Cultura, 2010. Disponível em: http://karlabru.net/site/publicacoes/cultura-digital-e-geolocalizacao/. Acesso: 01/09/2014.

BRUNO, Fernanda. Monitoramento, classificação e controle nos dispositivos de vigilância digital. Compós 2008, Disponível em: http://www.compos.org.br/data/biblioteca_365.pdf. Acesso: 11/11/2013.

BUCKER-COHEN, J. Wi-Fi Hog, da reação à realização. In: BEIGUELMAN, G. (et. al) (org.). Apropriações do (In) Comum: Espaço público e privado em tempos de Mobilidade. São Paulo: Instituto Sérgio Motta, 2009.

BUENO, C. Concepções de espaço: do Renascimento às Realidades Mistas. In: Revista Eletrônica Arte.Mov. São Paulo, 2007. Disponível em: http://www.artemov.net/page4/revistas.php?edition=13\&article=48. Acesso: 12/09/2014.

CARERI, Francesco. Walkscapes: El Andar como Práctica Estética. Maurici Pla (Trad.). Col. Land\&Scape Séries. Barcelona: Editorial Gustavo gili, Sl, 2009.

CASTELLS, Manuels. A Sociedade Em Rede. [S. L] : Paz E Terra, 2000.

CASTLE, Helen (Ed.), AD Architectural Design Emergence: Techniques and Technologies in Morphogenetic Design. Vol. 76, n² 2, Wiley Academy, London, March/April 2006.

CASTLE, Helen. Morphogenetic Design Strategies. In: AD Architectural Design Emergence, vol. 74, no 3. London: Wiley-Academy, 2004.

COUCHOT, Edmond. A Tecnologia na Arte: da Fotografia à Realidade Virtual. Porto alegre: ed. UFRGS, 2003.

DA COSTA, L. Bernardino. Imagem Dialética/ imagem Crítica: Um Percurso de Walter Benjamin a Georges Didi-Huberman. In: V Encontro de História da Arte - IFCH / UNICAMP, 2009. Disponível

em:http://www.unicamp.br/chaa/eha/atas/2009/DA\%20COSTA,\%20Luciano\%20Bernadino\%20-\%20VEHA.pdf, Acessado em 27/07/2015.

DEBORD, Guy. Introdução a uma crítica da Geografia Urbana. Publicado no \# 6 de Les lévres nues (revista belga setembro 1955). Disponível em http://antivalor.atspace.com/is/geourba.htm. Acesso: 01/08/2014.

DELEUZE, G; GUATTARI, F. Mil Platôs: capitalismo e esquizofrenia. Vols.:1, 3 e 5 São Paulo: Ed. 34, 1997. . Conversações, 1972-1990. Rio de Janeiro : Ed. 34, 1992.

Post-Scriptum sobre as Sociedades de controle. in Deleuze, G. Conversações: 1972-1990, Ed. 34, pp.

219-226, 1992. Disponível em : http://disciplinas.stoa.usp.br/Deleuze_Post scriptum sobre as sociedades de controle.pdf. Acesso: 01/08/2014.

. Bergsonismo. Trad Luiz B. L. Orlandi. São Paulo: Editora 34, 2012.

0 atual e 0 Virtual. In : ALLIEZ, Eric. Deleuze Filosofia Virtual. São Paulo: Editora 34, 1996.

DIDI-HUBERMAN, G. 0 que Torna o Tempo Legível é a Imagem. Entrevista realizada por Susana Nascimento Duarte E Maria Irene Aparício. Disponível em:

http://www.raf.ifac.ufop.br/pdf/artefilosofia 11/0 que torna_o tempo.pdf. Acesso: 14/12/2015.

DIDI-HUBERMAN, G. 0 que Vemos e o que Nos Olha. São Paulo: Ed. 34, 1999.

DOMINGUEZ e STAULBAUM. Transborder Immigrant Tool: Um Projeto Artístico de Perturbação entre a Fronteira dos Estados Unidos e México. In: Lucas Bambozzi (et. al.) (org.). Mediações Tecnologia e Espaço Público: Panorama Crítico da Artes em Mídias Móveis. São Paulo: Editora Conrad do Brasil, 2010. p. 183-185.

FLUSSER, V. 0 Mundo Codificado: Uma Filosofia do Design. São Paulo: Cossac Naify, 2010.

. Filosofia da Caixa Preta. São paulo: Annablume, 2001.

FOCAULT, Michel. As Palavras e as Coisas: Uma arqueologia das ciências humanas. São Paulo: Martins Fontes, 2000.

. Vigiar e Punir: História da Violência nas Prisões. São Paulo: Ed. Vozes, 1987.

De Outros Espaços, 1984. In: Architecture, Mouvement, Continuité. Disponivel em:

http://issuu.com/rizoma.net/docs/anarquitextura. Acesso: agosto de 2014. 
FONTCUBERTA, Joán. Por un Manifiesto pos fotográfico. In: La Vanguardia, 2011. Disponível em: http://www.lavanguardia.com/cultura/20110511/54152218372/por-un-manifiesto-posfotografico.html Acesso em: 27/07/2015.

FURTADO, G.; FEIO, A. 0 corpo no Espaço da Técnica Digital. Lisboa: s/i, 2002.

GALLOWAY, A. Locative Media As Socialising And Spatializing Practice: Learning From Archaeology. Leonardo Electronic Almanac, MIT Press. Disponível em http://www.purselipsquarejaw.org/papers/galloway ward draft.pdf 2005. Acesso: outubro de 2013;

GARRAUD, Colette. A Idéia de Natureza na Arte Contemporanea. Paris: Flamarion, 1994 GUATTARI, F. Caosmose: Um Novo Paradigma Estético. São Paulo: Ed. 34, 1992. . Revolução Molecular: Pulsações Políticas do Desejo. São Paulo: Editora Brasiliense, 1985. (2ªEd.) . Espaço e poder: a criação de territórios na cidade. Espaço e Debates, n. 16, ano V. São Paulo: Cortez, 1985. Disponível em: http://bibliotecavirtual.clacso.org.ar/ar/libros/osal/osal16/D16TRibeiro.pdf. Acesso: 01/08/2014.

IPPOLITA. En el Acuario De Facebook: El Iresistible Acenso del Anarco-Capitalismo. Giuseppe Mayo (Trad.) Madrid: Ed. Enclave, 2012.

JACQUES, Paola Berenstein. (Organização e Apresentação). Apologia da Deriva: Escritos Situacionistas Sobre a Cidade/ Internacional Situacionista. Tradução Estela dos Santos Abreu.1ª Ed. Rio de Janeiro: Casa da Palavra, 2003.

. Elogio aos Errantes: Breve Histórico das Errâncias Urbanas. Arquitextos nº 053, 2004, p. 01-05. Disponivel em: http://www.vitruvius.com.br. Acesso em: 15/02/2015.

JESUS, 0. Living Machines. Lisboa: s/i. 2002. Disponível em: http://arch.virose.pt/writings - Acesso: Agosto de 2013.

KINSLEY, Sam. Smart Mobs \& Cybrid Spaces. Undergraduate Dissertation, University of Plymouth, Digital Art \& Technology, 2003. Disponível em: http://www.samkinsley.com

KRANENBURG, Rob Von. The Internet of Things: A critique of ambient technology and the all-seeing network of RFID. In: Institut of Network Cultures. Amsterdam: Insitute of Network Cultures, 2008. Disponivel em: http://networkcultures.org. Acesso: outubro de 2013.

KRAUSS, Rosalind. A Escultura no Campo Ampliado. (Trad.: Elizabeth Carbone Baez). Gávea: Revista Semestral do Curso de Especialização em História da Arte e Arquitetura no Brasil. N01. Rio de Janeiro: PUC-RJ, 1984.

KUITENBROUWER, K. The Cultural and Social Possibilities of RFID. 2006. n. 11, Disponível em: em http://www.realtechsupport.org/UB/Aml/texts/Kuitenbrouwer_RFID_2006.pdf. Acesso:11/2013.

KWON, Miwon. One place after another : Notes on site-specific. In: October, Vol. 80. New York: MIT Press, 1997, pp. 85-110.

LATOUR, Bruno. On technical Mediation. Philosophy, Sociology, Genealogy. In: Common Knowledge, fall, v.3, n.2, 1994 b.

LEÃO, Lucia. Derivas: Cartografias Do Ciberespaço. São Paulo: Annablume, 2004.

LEFEBVRE, Henri. A Cidade do Capital. Trad.: Maria Helena R. Ramos e Marilene Jamut. Rio de Janeiro: DP\&A, 1999.

. A Produção Do Espaço. Trad. Doralice Barros Pereira e Sérgio Martins. Paris: Éditions Anthropos, 2000. LEMOS, A. Cidade e Mobilidade. In: Giselle Beigelman(et.al.) (org.). Apropriações do (in)comum: espaço público e privado em tempos de mobilidade. São Paulo: Inst. Sérgio Motta, 2009. p. 44-61

. Comunicação e Práticas Sociais no Espaço Urbano: As Características nos Dispositivos Híbridos Móveis ne Conexão Multi-redes (DHMCM). In: Revista Comunicação, Mídia e Consumo, v.4, n.10. São Paulo, 2007. p.23-40

. Manifesto sobre as Mídias Locativas. Salvador: Centro de Estudos e Pesquisas em Cibercultura ano 9 , n.71, mai.jun. 2009a. Disponível em: http://andrelemos.info. Acesso: novembro de 2013.

Mídia Locativa e Território Informacional. Canet de notes. Acessado 2007. Disponível em:

http://www.facom.ufba.br/ciberpesquisa/andrelemos/locativa.zip 2007. Acesso: novembro de 2013. 
. Ciberespaço e Tecnologias Móveis: processos de Territorialização e Desterritorialização na

Cibercultura. IN: Compós, Bauru: 2006. Disponível em:

http://www.facom.ufba.br/ciberpesquisa/andrelemos/territorio.pdf. Acesso em: 11/11/2015.

. Cidade-Ciborgue: A Cidade Na Cibercultura. In.: Revista Galáxia. Revista do Programa de Pós-

Graduação em Comunicação e Semiótica. São Paulo: PUC-SP, 2004

Cultura da Mobilidade. In: BEIGUELMAN, G. e LA FERLA, J. (Orgs.). Nomadismos Tecnológicos. São

Paulo: Editora SENAC, 2011.

. Mídia Locativa e Territórios Informacionais. s/i, 2006. Disponível em:

http://culturaderede.pbworks.com/f/midia\%20locativa andre\%20lemos.pdf Acesso: 14/12/2015.

. Mídias Locativas Vigilância: Sujeito Inseguro, Bolhas Digitais, Paredes Virtuais E Territórios

Informacionais. In: Surveillance in Latin America. Curitiba: PUC-PR, 2009. p. 621-648

LÉVY, P. A Inteligência Coletiva: Por uma Antropologia do Ciberespaço. São Paulo: Edições Loyola, 2007.

. As Tecnologias Da Inteligência: 0 Futuro do Pensamento na Era da informática. Trad.: Carlos Irineu da Costa. São Paulo: Ed. 34, 1995.

LIMA, Rodrigo N. Surrealismo e a Internacional Situacionista: Deambulações e Derivas. In: TREVISAN, Ricardo (Orgs.) Tempos e escalas da cidade e do urbanismo: Anais do XIII Seminário de História da Cidade e do Urbanismo. Brasília, DF: Universidade Brasília- Faculdade de Arquitetura e Urbanismo, 2014.

MACHAD0, A. A Imagem Eletrônica: Problemas da Representação. Face, vol. 2, nº 1, jan. - jun. 1989.

MACIEL, Kátia; PARENTE, André (orgs.). Redes Sensoriais: Arte, Ciência e Tecnologia. Rio de Janeiro: s/i.

MANOVICH, L. The Poetics of Augmented Space: Learning from Prada. In Noemalab, 2005. Disponível em http://www.noemalab.org/sections/ideas/ideas_articles/manovich_augmented_space.html . Acesso: Novembro de 2013.

McLUHAN, Marshall. Os meios de Comunicação como Extensões do Homem. São Paulo: Cultrix, 1970.

MEDEIROS, Maria Beatriz (coord.). Arte e Tecnologia na Cultura Contemporânea. Brasília: Duplográfica/UNB, 2002.

MITCHELL, W. J., Me ++. The Cyborg, Self and the Networked City. New york: MIT, Cambridge, MA, 2003.

.E-topia: Urban Life, Jim-But Not as We Know it. Nova York: Mit Press, 2000.

MONEO, R. Inquietação Teórica e Estratégia Projetual na Obra de Oito Arquitetos Contemporâneos. São Paulo: Cossac Naify, 2008.

NESBIT, K. (org.). Uma nova Agenda para a Arquitetura: Antologia Teórica 1965-1995. São Paulo: Cossac \& Naify, $2^{\text {a }}$ ed. Rev. 2008.

NOVAK, M. Transmitting Architecture: The Transphysical City CTheory . Disponivel em:

ww.ctheory.net/articles.aspx?id=76, 1996. Acesso: novembro de 2013.

NUNES, F. O. CTRL+ART+DEL: CONTEXTO, ARTE E TECNOLOGIA. São Paulo: Universidade de São Paulo, 2007.

PALLAMIN, Vera. Arte Urbana. São Paulo. Região central (1945-1998).

In: http://www.usp.br/fau/fau/ensino/docentes/deptecnologia/v_pallamin/index.html . Acesso: novembro de 2013.

PARENTE, André (Org.). Imagem-Máquina: A Era das Tecnologias do Virtual. Rio de Janeiro: Ed. 34, 2011. (4

Ed.)

PIMENTA, Emanuel Dimas. Teleantropos: A Desmaterialização da Cultura Material. Arquitectura Enquanto Inteligência e Metamorfose Planetária. Lisboa: Editorial Estampa, 1999.

PRADO, G; BUENO. C. Lugares Provisórios. In: Revista USP, São Paulo, nº 86, p.78-95. Junho/agosto de 2010. ."arte en red: algunas indagaciones sobre Creación, experimentación y trabajo Compartido" in Arte y

Políticas de Identidad, n. 1. Murcia, universidad de Murcia, 2009, pp. 241-250

Arte telemática: dos intercâmbios pontuais aos ambientes virtuais multiusuário/ Appresentação

Arlindo Machado, Julio Plaza - São Paulo: Itaú Cultural, 2003.

."Experimentações Artísticas em Redes Telemáticas e Web". In Arte Brasil. São Paulo, Unesp, n.1, ano 1, agosto de 1998, p. 42-47. "Desertesejo: um projeto artístico de ambiente virtual multiusuário na Internet". In Cadernos da Pós-Graduaçã o I. A. Campinas. Unicamp, Vol 4, no 1, 2000, p. 40-53. 
PRODANOV, C.C. Metodologia do trabalho científico [recurso eletrônico] : métodos e técnicas da pesquisa e do trabalho acadêmico / Cleber Cristiano Prodanov, Ernani Cesar de Freitas. - 2. ed. - Novo Hamburgo:

Feevale, 2013.

RANCIÈRE, J. A Partilha do Sensível: Estética e Política. São Paulo: Ed.34, 2005.

RHEINGOLD, H. Smart mobs: the Next Social rovolution. Cambridge: Basic, 2003.

RUSSEL, B. The Headmap manifesto. Disponível em: http://technoccult.net/wp-

content/uploads/library/headmap-manifesto.pdf Acesso: 11/11/2015.

SANTAELLA, L. Linguagens líquidas na era da mobilidade. São Paulo: Paulus, 2007.

. L.. Mídias locativas: a internet móvel de lugares e coisas. In: Revista Famecos, n.35. Porto Alegre:

Famecos, 2008. Disponível em:

http://www.revistas.univerciencia.org/index.php/famecos/article/viewArticle/5371

. A Estética Política das Mídias Locativas. In: Nómadas, n. 28. Abril 2008. Disponível em:

http://bibliotecavirtual.clacso.org.ar/ar/libros/colombia/iesco/nomadas/28/12- estetica.pdf. Acesso:

12/02/2016.

. Da cibercultura das Mídias a Cibercultura: 0 Advento do Pós-humano. In: Revista FAMECOS • Porto

Alegre $\bullet$ no $22 \cdot$ dezembro 2003. Disponível em:

http://revistaseletronicas.pucrs.br/ojs/index.php/revistafamecos/article/vie wFile/3229/2493. Consultada em: 08/ 2013;

. Linguagens Líquidas na Era da Mobilidade. São Paulo: Paulus, 2007.

SCHWARZ, G. Identidade, Valor e Mobilidade, por uma Iconomia dos Motoboys em São Paulo. In: LEMOS, A. e JOSGRILBERG, F. (Orgs.). Comunicação e Mobilidade: Aspectos Socioculturais das Tecnologias Móveis de Comunicação no Brasil. Salvador: UFBA, 2009. p.51-67

SHEPARD, Mark. (2007). Locative Media As Critical Urbanism. Disponível em:

http://www.spatialturn.de/Abstracts/Shepard.pdf. Acesso: 11/2013.

. Locative Media as critical urbanism. 2007. Disponível em:

http://transition.turbulence.org/blog/2007/09/04/locative-media-art Acessado em 12/11/2015.

SIMONDON, Gilbert. Du Mode d'exsitence des objects Techniques. Paris: Editions AUBIER, 2005.

SMITHSON, Robert. Um Passeio pelo Monumentos de Passaic, Nova Jersey. In: Revista Temática, 2012. p. 163-

167. Disponivel em: http://www.ppgav.eba.ufri.br/wp-content/uploads/2012/01/ae22_-Robert_Smithson.pdf.

Acesso: 16/07/2015.

SOBEK, Werner. Show me the future. Avedition: Germany, 2004.

SOUZA e SILVA, A. Do ciber ao Híbrido: Tecnologias Móveis como Interfaces de Espaços Híbridos. In: Imagem (Ir)realidade. $s / \mathrm{i}$

SPUYBROEK, L. The Architecture of Variation. London: Thames\& Hudson Ltd, 2009.

TED KRUEGER. Metadermis: Like a second skin. In:Prototypo 03; StereoMatrix; Lisbon; 2000

TOURAINE, Alain. Um novo Paradigma para Compreender o Mundo de Hoje. Petrópolis: Ed. Vozes, 2007.

TRAMONTANO, M.; PRATSCHKE, A.; MARCHETTI, M. Um toque de imaterialidade: 0 impacto das novas mídias no projeto do espaço doméstico. In: Del Rio, V. Duarte, C., Rheingantz, P. (orgs.) Projeto do lugar: colaboração entre psicologia, arquitetura e urbanismo. Rio de Janeiro: ProArq, 2002.

TRIBE, M. \& JANA, R. Arte Y Nuevas Tecnologias. Barcelona: Taschen GmbH, 2006.

TUTERS, M.; VARNELIS, K. Beyond The Locative Medias: Giving Shape to the Internet of Things. In: Leonardo, no 39 (vol. 4) 2006. p. 357-363.

VARGAS, J.D.V. Branding na sociedade do Espetáculo. Dissertação de Mestrado. São Paulo: Universidade de São Paulo, 2012.

VAYSSE, Jean-Marie (Ed.). Technique, Monde, Individuation: Heidegger, Simondon, Deleuze. Zürich: Georg OLMS Verlag, 2006.

VV. AA (D), Genetic Architectures II: digital tools \& organic forms. Site Books/ESARQ(UIC), Barcelona, 2005. WEISER, Mark. "The Computer for the Twenty-First Century". In: Scientific American. N.Y.: Scientific American 1991, p. 66-75. 
YEREGUI, Mariela. Móveis em Movimento: Corpo e Território na cena pós-midiática. In: Nomadismos tecnológicos. Jorge La Ferla e Giselle Beiguelman (organizadores). Sã o Paulo: Ed. Senac, 2011.

ZELLNER, Peter. Hybrid Spaces: New Forms in Digital Architecture. London: Thames \& Hudson Ltd, 2000.

\section{Glossário De Termos Técnicos:}

- DIY - Do It Yourself (Trad.: Faça Você Mesmo) é um fenômeno analiticamente complexo que se refere tanto às práticas independentes de produção musical e literária intensificadas pelo movimento punk a partir da década de 70 , quanto aos modos de construir, modificar, reutilizar ou reparar artefatos sem a necessidade de um profissional especializado. Atualmente esta prática têm se difundido a partir dos movimentos Maker e Open Design; No Brasil, o termo "gambiarra" traduz esta prática;

- GPS - Global Positioning System (Trad.: Sistema de Posicionamento Global) é uma infraestrutura de localização terrestre desenvolvida pelo Departamento de Defesa dos Estados Unidos. 0 GPS é formado pelos segmentos: espacial, de controle e receptor. 0 seguimento espacial é composto por 24 satélites construídos pela empresa Rockwell e lançados na órbita terrestre entre os anos de 1978 e 1985, sendo distribuídos em seis planos orbitais, de tal forma que cada um circula a Terra duas vezes por dia a uma velocidade de $1.1265 \mathrm{~km} / \mathrm{h}$, sendo que a qualquer momento, pelo menos 4 deles são rastreáveis de qualquer ponto da Terra. 0 segmento de controle é composto por 6 estações terrestres distribuídas ao redor do globo. Cada estação é responsável por monitorar, corrigir e modificar parâmetros orbitais do sistema GPS. 0 segmento do utilizador é composto pelos receptores GPS massivamente difundidos, responsáveis pela captação dos sinais fornecidos pelos satélites. Os receptores captam os sinais eletromagnéticos de quatro satélites e calculam a distância de cada um deles pelo intervalo de tempo entre 0 instante local e 0 instante em que os sinais foram enviados, descodificando as localizações dos satélites a partir de uma base de dados interna, que possibilita rastrear o horário e a localização de cada receptor na superfície terrestre. Existem atualmente dois sistemas efetivos de posicionamento por satélite; o GPS (EUA) e o Glonass (Russo), além de dois sistemas em implantação: 0 Galileo europeu e o Compass, chinês.

- LBS - Location Based Services (Trad.: serviços baseados em localização) ou LCS - Location Services (Trad.: Serviços de Localização) se referem a um conjunto de dispositivos e sistemas tecnológicos que operam produzindo, detectando, rastreando ou disponibilizando dados de geolocalização de sues usuários. Tais dispositivos estão cada vez mais associados às tecnologias móveis tais como sitemas wi-fi, 3G, 4G, Rfid, GPS, smartphones, etc. Segundo Alex Küpper (2005), em "Location-based services fundamentals and operation", LBS se define por um sistema que integra dados de localização geográfica à dispositivos móveis produzindo dados de mobilidade;

- Metadados ou Metainformação são dados sobre outros dados, ou seja, meios de organização que permitem circunscrever a informação em categorias para tornar mais fácil a sua compreensão. Os metadados facilitam o entendimento das relações entre dados e a utilidade de suas informações.

- Qr-code - Quick Response Code (trad.: código de resposta rápida ) é um código de barras bidimensional que pode ser facilmente escaneado pela maioria dos telefones celulares equipados com câmera. Esse código é convertido em texto (interativo), um endereço URI, um número de telefone, uma localização georreferenciada, um e-mail, um contato ou um SMS; 
- Realidade mista - criada nos anos 1990 por Paul Milgram. Realidade mista consiste em objetos virtuais interagindo com o espaço físico. Há quatro graus de interação em realidade mista: realidade total (a que vivemos), realidade aumentada (virtual ajuda a ampliar o real), virtualidade aumentada (real ajuda a ampliar o virtual) e realidade virtual total (quando a consciência está no virtual). Nenhuma dessas três últimas realidades foi $100 \%$ explorada, por falta de aparatos tecnológicos e pesquisa.

- R.a. - Augmented Reality (trad.: realidade aumentada) ${ }^{63}$ promove a integração entre 0 espaço físico e o virtual através da mediação de dispositivos móveis e softwares capazes de produzir, anexar, rastrear e interpretar dados relativos a uma determinada geolocalização, seja via imagens ou coordenadas numéricas.

- Rede de transmissão wifi - modelo 802.11b - é um conjunto de especificações para redes locais sem fio (WLAN - Wireless Local Area Network) baseada no padrão IEEE 802.11. Trata-se de uma abreviatura do termo "Wireless Fidelity", embora a Wi-Fi Alliance, entidade responsável principalmente pelo licenciamento de produtos baseados na tecnologia, nunca tenha afirmado tal conclusão. Fonte: http://www.ieee802.org Acesso em: 12/02/2016.

- Redes 3G, 4G - 0 padrão 3G é a terceira geração de padrões e tecnologias de telefonia móvel, baseadas na família de normas da União Internacional de Telecomunicações (UIT). 4G é a sigla para a Quarta Geração de telefonia móvel. A tecnologia 4G está baseada totalmente em IP (Internet Protocol), sendo um sistema e uma rede que alcança a convergência entre as redes de cabo e sem fio e computadores, dispositivos eletrônicos e tecnologias da informação para prover velocidades de acesso entre 100 Megabites;

- Rfid - Radio-Frequency IDentification (Trad.IIdentificação por radiofrequência) é um método de identificação automática através de sinais de rádio, que produz, armazena e recupera dados remotamente através de dispositivos denominados etiquetas RFID;

- Tic's $s^{64}$ (tecnologias da informação e comunicação) - consiste em todos os meios técnicos usados para tratar a informação e auxiliar na comunicação, o que inclui o hardware de computadores, rede, telemóveis, bem como todo software necessários e a infraestrutura informacional.

- Streaming (Trad.: Fluxo de mídia) - é uma forma de distribuição de dados em uma rede através de pacotes fechados de informação. É freqüentemente utilizada para distribuir conteúdo multimídia através da Internet. Em streaming, as informações não são armazenadas pelo usuário em seu próprio computador não ocupando espaço no Disco Rígido (HD), ele recebe o "stream", a transmissão dos dados (a não ser a arquivação temporária no cache do sistema ou que o usuário ativamente faça a gravação dos dados) - a mídia é reproduzida à medida que chega ao usuário;

${ }^{63}$ Paramais informações sobre Realidade Aumentada e Realidade Virtual, acessar: http://www.marcelohsantos.com.br/aulas/downloads/2Semestre_2014/novasmidias/Jogos_PE_Novas_Midias e_Tecnologias_para_ogos_Aula4_01.pdf. Acesso em: 12/02/2016

${ }^{64}$ Para mais informações sobre as tecnologias da informação e comunicação, acessar: http://periodicos.uesb.br/index.php/cadernosdeciencias/article/viewFile/884/891 Acesso em: 12/02/2016 
Lista de Imagens:

- Figura 1 - Marcos Novak - Diagramas de transvergência. Disponível em: http://www.mnovak.com.br

- Figura 2 - Lars Spuybroek - Pavilhão da água construído por ocasião da expo fresH2O eXPO. Disponível em: www.teses.usp.br/teses/disponiveis/16/..//sabela_Ferrante_Dissertacao.pdf.

- Figura 3,4 e 5 - Lars Spuybroek - Vistas internas do Pavilhão da Água Doce construído por ocasião da exposiçao fresH2O eXPO. Disponível em: www.teses.usp.br/teses/disponiveis/16/.../sabela_Ferrante_Dissertacao.pdf.

- Figuras 6 e 7 - Lars Spuybroek - Vistas externas do Pavilhão da Água Doce construído por ocasião da exposiçao fresH2O eXPO. Disponível em: www.teses.usp.br/teses/disponiveis/16/.../sabela_Ferrante_Dissertacao.pdf.

- Figura 8 - Greg Lynn - Plano de evolução da Casa Embriológica - Ebriological House. Disponível em: http://www.docam.ca/conservation/embryological-house/GL3ArchSig.html. Acesso em: 21/09/2015.

- Figura 9 - Greg Lynn - Modelo tridimensional de membrana flexível. Disponível em: http://www.docam.ca/conservation/embryological-house/GL3ArchSig.html. Acesso em: 21/09/2015.

- Figura 10 - Greg Lynn - visualização da forma primitiva simétrica que funciona como base inicial para as interações (criada no programa Microstation);Disponível em: http://www.docam.ca/conservation/embryological-house/GL3ArchSig.html. Acesso em: 21/09/2015.

- Figura 11 - Greg Lynn - Desenvolvimento do modelo 3D interativo da Casa Embriológica (criado no programa Maya)Disponível em: http://www.docam.ca/conservation/embryologicalhouse/GL3ArchSig.html. Acesso em: 21/09/2015.

- Figura 12 - Greg Lynn - Algoritimos de interatividade; Disponível em: http://www.docam.ca/conservation/embryological-house/GL3ArchSig.html. Acesso em: 21/09/2015.

- Figura 13 - Greg Lynn - modelo interativo; Disponível em: http://www.docam.ca/conservation/embryological-house/GL3ArchSig.html. Acesso em: 21/09/2015.

- Figura 14 - Karl Chu - Plano de evolução do espaço genético a partir da Máquina de Turing; Imagens disponíveis em: http://www.docam.ca/conservation/embryological-house/GL3ArchSig.html. Acesso em: 21/09/2015.

- Figura 15 - Pranav mistry - método de interação entre o computador vestível e 0 ambiente Imagens disponíveis em: http://www.pranavmistry.com/projects/sixthsense/\#PICTURES. Acesso em $5 / 10 / 2015$

- Figura 16 - CYSMN? - Jogador em ação Imagens disponiveis em: http://www.blasttheory.co.uk/projects/can-you-see-me-now. Acessado em: 12/02/2016;

- Figura 17 - CYSMN? - torre de transmissão Imagens disponíveis em: http://www.blasttheory.co.uk/projects/can-you-see-me-now. Acessado em: 12/02/2016;

- Figura 18 - CYSMN? - Sala de Controle, edição Vivo Arte.Mov no bairro de Santa Teresa - Belo horizonte - MG (2006). Imagens disponíveis em: http://www.blasttheory.co.uk/projects/can-yousee-me-now. Acessado em: 12/02/2016;

- Imagens disponíveis em: http://www.blasttheory.co.uk/projects/can-you-see-me-now. Acessado em: 12/02/2016;

- Figura 19 - CYSMN? - Interface da homepage do jogo contendo o posicionamento dos jogadores em um mapa esquemático da cidade;Imagens disponíveis em: http://www.blasttheory.co.uk/projects/can-you-see-me-now. Acessado em: 12/02/2016;

- Figura 20 - CYSMN? - Sub-sistema de mensagens de texto e posicionamento dos jogadores;Imagens disponíveis em: http://www.blasttheory.co.uk/projects/can-you-see-me-now. Acessado em: 12/02/2016; 
- Figura 21 - CYSMN? - Esquema do Sub-sistema de Áudio.Imagens disponíveis em: http://www.blasttheory.co.uk/projects/can-you-see-me-now. Acessado em: 12/02/2016;

- Figura 22 - ZAPPED! - Mapeamento interativo das redes de Rfid na cidade de Tokyo. Imagens disponíveis em: http://preemptivemedia.net/zapped/index.html. Acesso em: 12/02/2016

- Figura 23 - ZAPPED! - Manual realizado pelo coletivo para as oficinas

- Figura 24- ZAPPED! - Chaveiro, Figura 25 (dir.) - Barata de Madagascar (Gromphadorhina portentosa)Imagens disponíveis em: http://preemptivemedia.net/zapped/index.html. Acesso em: $12 / 02 / 2016$

- Figura 26 e 27 - ZAPPED! - Workshop. Imagens disponíveis em: http://preemptivemedia.net/zapped/index.html. Acesso em: 12/02/2016

- Figura 30 - ZAPPED! - Leitor Rfidlmagens disponíveis em: http://preemptivemedia.net/zapped/index.html. Acesso em: 12/02/2016

- Figura 32 - Tatical Sound Garden - Esquema de funcionamento do Sound Garden;Imagens disponiveis em: http://www.tacticalsoundgarden.netAcesso em: 12/02/2016

- Figura 32 - Tatical Sound Garden - Esquema de funcionamento do Sound Garden;Imagens disponíveis em: http://www.tacticalsoundgarden.netAcesso em: 12/02/2016

- Figura 33 - Transborder Immigrant Tool - Interface do aplicativo em funcionamento; Disponível em: http://www.tacticalmediafiles.net/articles/3472/Transborder-Immigrant-Tool-ProjectDescription;jsessionid=56877F17FC62445B7C706BC28560A9EB. Acesso em: 12/02/2016

- Figura 34 - Transborder Immigrant Tool - Interface e funcionamento do Transborder Immigrant Tool; Disponível em: http://www.tacticalmediafiles.net/articles/3472/Transborder-Immigrant-ToolProject-Description;jsessionid=56877F17FC62445B7C706BC28560A9EB. Acesso em: 12/02/2016

- Figura 35 - Megafone .net - Localização de projetos; Disponível em: http://megafone.net/site/index. Acesso em: 12/02/2016;

- Figura 36 - Megafone.net - Página dos motoboys; Disponível em: http://megafone.net/site/index. Acesso em: 12/02/2016;

- Figura 37 - Megafone.net - Pagina Inicial do Site; Disponível em: http://megafone.net/site/index. Acesso em: 12/02/2016; 